Beatriz Nogueira Messias de Miranda

\title{
Clonagem, expressão e purificação de alfa receptores de folato de Homo sapiens para aplicações bioanalíticas em câncer
}

\author{
\begin{tabular}{|c|}
\hline Exemplar revisado \\
O exemplar original encontra-se em \\
acervo reservado na Biblioteca do IQSC-USP
\end{tabular}
}

Dissertação apresentada ao Instituto de Química de São Carlos da Universidade de São Paulo como parte dos requisitos para a obtenção do título de mestre em ciências.

Área de concentração: Química Orgânica e Biológica

Orientador: Prof. Dr. Emanuel Carrilho

São Carlos 
Dedicatória

Dedico este trabalho aos meus pais, meus exemplos e maiores incentivadores. 


\section{Agradecimentos}

Agradeço ao Prof. Dr. Emanuel, pela oportunidade de orientação, pela confiança no desenvolvimento do trabalho e pela amizade.

Aos queridos BiôMicoS que fizeram do dia-a-dia muito mais divertido e prazeroso.

Em especial agradeço à Fay, Ka, Regiane, Júlia, Sheila, Ju A., Paulo, Ju B. e Thiago por me receberem de braços abertos desde que cheguei no grupo, por todo apoio que me deram para conclusão do meu projeto e, principalmente, pelos momentos de descontração, dentro e fora do laboratório.

Ao Prof. Dr. David Weitz por me receber e orientar no estágio desenvolvido na Universidade de Harvard em Boston, e seu grupo. Em especial agradeço ao Ali pela coorientação durante este período.

À Profa. Dra. Fernanda Canduri e grupo por disponibilizar o laboratório para o desenvolvimento da pesquisa, pela disponibilidade e confiança.

À Profa. Dra. Dulce pela amizade e por continuar me orientando, mesmo de longe. Às amigas Ariele, Camilla, Pri e Mônica pela amizade de sempre e pela colaboração.

Ao Prof. Dr. Gerhard Wunderlich pela colaboração e por disponibilizar o seu laboratório para o desenvolvimento de parte do trabalho. Agradeço a todos do seu grupo e, em especial ao Wesley que se prontificou a me ajudar e contribuiu sobremaneira para que o projeto fosse concluído conforme descrito.

Ao Dyovani pela disponibilidade e ajuda no desenvolvimento de determinados experimentos.

Aos meus queridos amigos Vanessa, Marina, Thais, Alvinho, Zigoto, Volta, Jeremias, Márcio e Coragem com os quais tenho a imensa alegria de ainda compartilhar muitos momentos agradáveis.

Aos professores e funcionários do DQ e do IQSC que de alguma forma contribuíram para a minha formação e desenvolvimento deste projeto.

À FAPESP (processos 2011/16364-6 e 2013/15892-4) pelas bolsas concedidas e pela oportunidade do estágio BEPE (Bolsa estágio de pesquisa no exterior) . 
Ao CNPq, à FAPESP e ao Instituto Nacional de Ciência e Tecnologia de Bioanalítica pelo apoio financeiro ao longo do desenvolvimento do projeto.

Aos meus pais, muito obrigada por tudo! O nosso sucesso é fruto do amor, carinho, amizade, incentivo e confiança de vocês depositados em nós em todas as etapas de nossas vidas.

À minha irmã pela amizade que mesmo com os "desencontros internacionais" persiste e se fortalece a cada dia. Independente de onde estivermos, estaremos sempre juntas.

Ao meu namorado, Lucas, pela imensa compreensão e incentivo, amor, amizade, carinho e pelos sonhos compartilhados que aos poucos vão se tornando realidade.

À minha família, avós, tios, tias, primos e primas, por todo amor, incentivo e a constante torcida em mais uma etapa de minha vida.

To Kay, Kevin, Holly, and Kelsey that accepted me as part of their family, I will always be thankful. The best family and experience I could have as a foreign exchange student. The internship opportunity I had during my master degree wouldn't be possible without your support in the past. 


\section{Resumo}

MIRANDA, B. N. M. Clonagem, expressão e purificação de alfa receptores de folato de Homo sapiens para aplicações bioanalíticas em câncer. 2014. 76 f. Dissertação (Mestrado em Química Orgânica e Biológica) - Instituto de Química de São Carlos, Universidade de São Paulo, São Carlos, 2014.

Nos últimos anos a incidência do câncer tem crescido significativamente mundialmente, porém, as técnicas atualmente empregadas para a detecção da doença não são individualmente conclusivas, além de serem extremamente invasivas e não permitirem seu diagnóstico precoce, o que justifica o desenvolvimento de novas tecnologias alternativas para a detecção do câncer. Células cancerígenas possuem receptores específicos de alta afinidade com folato e por serem altamente replicativas, são extremamente dependentes do suprimento de folato reduzido. Os alfa-receptores de folato $(\mathrm{FR} \alpha)$ são proteínas com propriedades bioquímicas específicas as quais podem ser exploradas pela estratégia de marcação para detecção e tratamento do câncer (biomarcadores). Com raras exceções, são induzidos seletivamente em tecidos cancerígenos e raramente expressos em células normais, mostrando-se, assim, altamente seletivos e específicos. Sendo assim, neste projeto objetivou-se a expressão e a purificação dos FRa, além da sua imobilização em microssistema para estudos subsequentes em biossensores. Foram promovidos testes de expressão da proteína heteróloga $(\mathrm{rFR} \alpha)$ em $E$. coli em diferentes linhagens, temperaturas e tempos de indução da expressão sendo observada a expressão da proteína recombinante de forma insolúvel. Paralelamente foram promovidos testes de expressão da proteína $\mathrm{rFR} \alpha$ em $P$. pastoris, os quais não se mostraram eficientes, uma vez que não foi possível a detecção da proteína em estudo. Como alternativa, uma nova construção, em fusão com a proteína Trigger factor $(\mathrm{TF})$ de E. coli, uma chaperona molecular de alta solubilidade, foi testada. Através de análises por SDS-PAGE, Western Blot, OFFGEL e espectrometria de massas, foi possível comprovar a produção da proteína recombinante TFFR $\alpha$. Ainda, a proteína foi imobilizada em lipossomos, o que proporcionou o desenvolvimento de um padrão analítico que poderá ser utilizado em estudos subsequentes com biossensores de FR $\alpha$. Este estudo será útil para o desenvolvimento de drogas visando a inativação desta proteína, como os anti-folatos, que são hoje os agentes anti-neoplásicos mais investigados, e possibilitará a caracterização bioanalítica da proteína FR $\alpha$ recombinante $(\mathrm{rFR} \alpha)$ bem como o desenvolvimento de novos biossensores.

Palavras-chave: Clonagem. Expressão heteróloga. Receptores de folato. Biomarcador. Câncer. 


\begin{abstract}
MIRANDA, B. N. M. Clonagem, expressão e purificação de alfa receptores de folato de Homo sapiens para aplicações bioanalíticas em câncer. 2014. 76 f. Dissertação (Mestrado em Química Orgânica e Biológica) - Instituto de Química de São Carlos, Universidade de São Paulo, São Carlos, 2014.
\end{abstract}

In recent years the incidence of cancer has grown significantly globally. Even though, the techniques currently employed for the detection of cancer are not individually conclusive due to the subjectivity of the analysis, inherently invasive, and are unable to provide early diagnosis. Therefore, the development of new technologies for cancer detection and prognostic are justified. Cancer cells have specific receptors with high affinity towards folate and are highly replicative. Alpha folate receptors $(\mathrm{FR} \alpha)$ are extracellular proteins with specific biochemical properties since, with rare exceptions, are induced selectively in cancerous tissues and rarely expressed in normal cells, being highly sensitive and specific. In this work we produced FR $\alpha$ heterologously and we immobilized it on a microsystem mimicking a cancer cell that will become an analytical standard for studies with biosensors. Firstly, we produced $\mathrm{rFR} \alpha$ in different $E$. coli strains, exploring variation of temperature and induction times, in which we observed the expression of insoluble protein. We also tried the expression in $P$. pastoris system, which was not efficient as well. Alternatively, we cloned FOLR1 gene in a special vector that enables the expression of FR $\alpha$ fusioned with the Trigger factor from E. coli, a highly soluble molecular chaperone. Using SDS-PAGE, Western Blot, OFFGEL and mass espectrometry we observed the production of soluble TFFR $\alpha$. The recombinant protein was immobilized in liposomes, producing an analytical standard for studies with FR $\alpha$-based biosensors. Our findings open research possibility in drug development, like anti-folates, besides the development of new biosensors.

Key-words: Cloning. Heterologous expression. Folate receptors. Biomarkers. Cancer. 


\section{Lista de Ilustrações}

Figura 1 - Estrutura química do ácido fólico.

Figura 2 - Sequências nucleotídica e de aminoácidos e da Proteína FR $\alpha$ de Homo sapiens. Em 6 amarelo esta destacada a sequência do peptídeo sinal.

Figura 3 - Representação estrutural da proteína FR $\alpha$, extremidades N- (azul) e C-terminal 7 (vermelho). Coordenadas da proteína 4RLH do Protein Data Bank.

Figura 4 - Esquema do processo de fracionamento de proteínas por OFFGEL (Agilent 10 Tecnhologies).

Figura 5 - Mapa do vetor de expressão pET28a clonado com o fragmento FOLR1 entre os sítios de restrição das endonucleases NdeI e XhoI. Esta construção possibilita a expressão da proteína FR $\alpha$ recombinante em fusão com $6 \times$ His-tag na porção $\mathrm{N}$-terminal da proteína, após um sítio de trombina.

Figura 6 - Representação esquemática da etapa de clonagem do FOLR1 no vetor modificado pRSETaTF.

Figura 7 - Predição do mapa do vetor modificado pRSETaTF clonado com o fragmento FOLR1 entre os sítios de restrição das endonucleases BamHI e SacI. Essa construção codifica a expressão da proteína rFR $\alpha$ em fusão com a proteína Trigger Factor (E. coli) na porção N-terminal da proteína, além de uma $6 \times$ His-tag, com resistência à ampicilina.

Figura 8 - Representação esquemática da metodologia de produção dos lipossomos.

Figura 9 - Representações estruturais do lipídeo DGS-NTA(Ni):1,2-dioleoil-sn-glicero-3-[(ácidoN-(5-amino1carboxipentil)iminodiacético)succinil] (sal de níquel).

Figura 10 Expressão $\mathrm{rFR} \alpha$ em BL21(DE3) a $30{ }^{\circ} \mathrm{C}$ por $5 \mathrm{~h}$. a) Perfil eletroforético em gel de SDS-PAGE $15 \%$ e b) Membrana de nitrocelulose Western Blot detecção direta com pastilha SigmaFAST ${ }^{\mathrm{Tm}}$ BCIP®/NBT B5655 (Sigma). Canaletas: M. Padrão de tamanho molecular (Fermentas); 1. Conteúdo proteico antes da indução $\left(\mathrm{t}_{\mathrm{o}}\right) ; 2$. Conteúdo proteico após a indução; 3. Fração solúvel do lisado celular; 4. Fração insolúvel do lisado celular, a $30{ }^{\circ} \mathrm{C}$ e $20{ }^{\circ} \mathrm{C}$, respectivamente. As bandas indicadas com setas representam a $\mathrm{rFR} \alpha, \operatorname{com} 28,3 \mathrm{kDa}$. 
Figura 11 Perfil eletroforético em gel SDS-PAGE 15\%. Expressão rFR $\alpha$ em a) 36 BL21(DE3)pTGROE a $30{ }^{\circ} \mathrm{C}$ por $5 \mathrm{~h}$ e em b) BL21(DE3)Rosetta a $30^{\circ} \mathrm{C}$ por $5 \mathrm{~h}$. Canaletas: M. Padrão de tamanho molecular (Fermentas); 1 e 2. Conteúdo proteico antes e após a indução, respectivamente; 3 e 4 . Frações solúvel e insolúvel do lisado celular, respectivamente.

Figura 12 Perfil eletroforético em gel SDS-PAGE 15\%. Teste de solubilidade da rFR $\alpha$ expressa em BL21(DE3) a $30{ }^{\circ} \mathrm{C}$ por $5 \mathrm{~h}$, com diferentes tampões de lise, I e II. Canaletas: M. Padrão de tamanho molecular (Fermentas); 1 e 2. Conteúdo proteico antes e após a indução, respectivamente; 3 e 5: Frações solúveis do lisado celular; 4 e 6. Frações insolúveis do lisado celular, com os tampões I (PBS 1×) e II (5\% glicerol), respectivamente. As bandas indicadas com setas representam a rFR $\alpha$, com 28,3 kDa.

Figura 13 Perfil eletroforético da reação de análise por restrição do clone pRSETaFOLR1 com a enzima EcoRI em gel de agarose 1\%. Canaleta M: Padrão de DNA 1 kB GeneRuler (Thermo Scientific). 1: pRSETaTF-FOLR1 digerido com EcoR1. Em destaque a banda referente ao inserto de $\sim 1200 \mathrm{pb}$.

Figura 14 Perfil eletroforético da PCR com o clone pRSETaTF-FOLR1 como DNA molde, em gel de agarose 1\%. Canaleta M. Padrão de DNA 1 kB GeneRuler (Thermo Scientific); 1. Controle negativo; 2. PCR com pRSETaTF-FOLR1. Em destaque o segmento de DNA amplificado.

Figura 15 Alinhamento da sequência proveniente da análise por sequenciamento do clone 40 pRSETaTF-FOLR1 com a sequência de DNA codificante da proteína FR $\alpha$.

Figura 16 Esquema representativo do novo tamanho esperado da proteína 41 recombinante TFFR $\alpha$.

Figura 17 Análise da expressão da TFFR $\alpha$ em BL21(DE3) RIL a $37{ }^{\circ} \mathrm{C}$ por 5 h. a) Perfil eletroforético em gel SDS-PAGE 10\%; b) Filme fotográfico obtido pela revelação do Western Blot, detecção secundária com Kit SuperSignal West Pico Chemiluminescent Substrate, Thermo Scientific. Canaletas M. Padrão de tamanho molecular Spectra ${ }^{T M}$ Multicolor Broad Range (Thermo Scientific); 1. Fração solúvel do lisado celular; 2. Eluição da coluna de Ni; PBS 1x + 250 mM Imidazol; 3. Expressão "padrão" da TF em outra fusão (controle positivo); 4. Eluição do controle positivo de TF. Em destaque a banda referente à TFFR $\alpha$ na amostra purificada. 
Figura 18 Análise de concentração e purificação da TFFR $\alpha$. a) Perfil eletroforético em gel SDS- 43 PAGE 10\%; b) Filme fotográfico obtido pela revelação do Western Blot, detecção secundária com Kit SuperSignal West Pico Chemiluminescent Substrate, Thermo Scientific. Canaletas: M. Padrão de tamanho molecular Spectra ${ }^{T M}$ Multicolor Broad Range (Thermo Scientific); 1. Fração eluida da coluna de concentração; 2. Fração concentrada pela coluna; 3. Fração eluida da coluna desalting; 4. Eluição do controle positivo de TF em fusão. Em destaque a banda referente à TFFR $\alpha$, podendo ser observadas bandas referentes à esta proteína truncada.

Figura 19 Análise de OFFGEL da amostra pré-purificada por cromatografia de afinidade. a) Perfil eletroforético em gel SDS-PAGE 12,5\% das frações dos compartimentos 1-11 sobre fita IPG de pH 3-10. Detalhe comparando o perfil eletroforético em gel das frações 5 e 6 (b) com o filme fotográfico obtido pela revelação do Western Blot, detecção secundária com Kit SuperSignal West Pico Chemiluminescent Substrate, Thermo Scientific (c).

Figura 20 Cromatograma do digerido triptico da banda referente à TFFR $\alpha(\sim 78 \mathrm{kDa})$ após pré45 purificação em coluna de Ni. As condições cromatográficas utilizadas foram descritas no ítem 1.11.4.

Figura 21 Resultado da digestão tríptica da proteína recombinante TF-FR $\alpha$, sendo mostrada apenas o resultado da digestão referente somente à porção do receptor. Em destaque os peptídeos encontrados (amarelo) e o início da proteína FR $\alpha$ (seta azul).

Figura 22 Eletrólito suporte tampão fosfato $0,2 \mathrm{~mol} \mathrm{~L}^{-1} \mathrm{pH} 7,2$. Adição de $1 \mathrm{~mL}$ da solução de tetrahidrofolato em $80 \mathrm{~mL}$ do eletrólito suporte. Experimento conduzido em OCP (potencial de circuito aberto) sob agitação magnética constante.

Figura 23 Análise da diálise e ligação da TFFR $\alpha$ a lipossomos. a) Perfil eletroforético em gel 50 SDS-PAGE 10\%; b) Filme fotográfico obtido pela revelação do Western Blot, detecção secundária com Kit SuperSignal West Pico Chemiluminescent Substrate, Thermo Scientific. Canaletas: M. Padrão de tamanho molecular Spectra ${ }^{T M}$ Multicolor Broad Range (Thermo Scientific); 1. Amostra TFFR $\alpha$ purificada e dialisada; 2. Sobrenadante dos lipossomos NTA; 3. Lipossomo sem Ni; 4. Lipossomo com Ni; 5. Amostra TFFR $\alpha$ purificada em coluna de Ni.

Figura 24 Intensidade das bandas observadas nos poços 2, 3 e 4 do Western Blot da Figura 23.

Figura 25 Imagem de microscopia ótica digital dos GPI-proteolipossomos, de células HeLa. 
Figura 26 Imagem de microscopia de força atômica (AFM) da amostra de GPI-proteolipossomos dispersa sobre mica e analisada no equipamento de AFM Nanosurf EasyScan 2, $50 \times$ $50 \mu \mathrm{m}$.

Figura 27 Desenho esquemático do mecanismo de inserção do plasmídeo (contendo o DNA codificante da proteína de interesse) ao DNA genômico da levedura, através do crossover entre o loci e uma das regiões AOX1 do plasmídeo pPICZ $\alpha$ previamente clonado. Eventos de multiplas inserções podem ocorrer.

Figura 28 Mapa do vetor pPICZ $\alpha$ A clonado com o fragmento FOLR1 entre os sítios de restrição das endonucleases EcoRI e NotI. Este inserto codifica a expressão da proteína FR $\alpha$ recombinante em fusão com uma cauda de histidina na porção N-terminal da proteína, além do fator- $\alpha$ de secreção. As setas em destaque referem-se ao gene que codifica a resistência ao antibiótico zeocina e o gene FOLR1 inserido.

Figura 29 Eletroforese em gel de agarose. Confirmação da extração do DNA genômico. Canaletas: 1-8. Amostras do DNA genômico extraído de oito colônias distintas.

Figura 30 Eletroforese em gel de agarose 1\%. Confirmação da clonagem do DNA genômico extraído através de PCR com primers 5'AOX1 e 3'AOX1. Canaletas: 1-8. Conteúdo da PCR das amostras do DNA genômico extraído das colônias 1-8, respectivamente. M: Padrão de 1 kb (Promega).

Figura 31 Eletroforese em gel de agarose. Confirmação da clonagem do DNA genômico extraído através de PCR com primers FOLR1R e FOLR1F. Canaletas: 1. Padrão de $1 \mathrm{~kb}$ (Promega); 2. Controle negativo; 3-10. Conteúdo da PCR das amostras do DNA genômico extraído das colônias 1-8, respectivamente.

Figura 32 Perfil de eletroforese em gel de SDS-PAGE 15\% corado com prata. Expressão da rFR $\alpha$ em P. pastoris a $30{ }^{\circ} \mathrm{C}$ em meio indutor BMMY, colônia 2. Canaletas: 1. Padrão de tamanho molecular (Fermentas); 2. Conteúdo proteico antes da indução $\left(\mathrm{t}_{\mathrm{o}}\right) ; 3$. Conteúdo proteico antes da indução $\left(\mathrm{t}_{\mathrm{o}}\right)$; 4-9. Conteúdo proteico depois de 24, 48, 72 , 96, 120 e 144 h de indução, respectivamente. 


\section{Lista de Tabelas}

Tabela 1 - Primers utilizados para clonagem no vetor modificado pRSETaTF.

Tabela 2 - Lista dos peptídeos comuns da FR $\alpha$ entre o experimento de digestão com tripsina real e o virtual.

Tabela 3 - Primers utilizados para reações de PCR. 


\section{Lista de abreviações e siglas}

- ACN: acetonitrila;

- AFM/MFA: Microscopia de força atômica;

- AmBic: solução de bicarbonato de amônio;

- BEPE: Bolsa estágio de pesquisa no exterior, FAPESP;

- CTC: célula tumoral circulante;

- 1-DE: eletroforese unidimensional;

- DGS-NTA(Ni):1,2-dioleoil-sn-glicero-3-[(ácido-N-(5aminolcarboxipentil)iminodiacético)succinil] (nickel salt);

- DMTHF: $\mathrm{N}^{5}, \mathrm{~N}^{10}$-dimetil tetrahidrofolato;

- DNA: ácido desoxirribonucléico;

- DPPC: 1,2-dipalmitoil-sn-glicero-3-fosfatidilcolina;

- DTT: ditiotreitol;

- EDTA: ácido etilenodiamino tetraacético;

- ESI: ionização por electrospray;

- FDA: Food and Drug Administration;

- GPI: glicosil fosfatidil inositol;

- GUVs: vesículas gigantes unilamelares;

- HeLa: linhagem celular humana derivada de células obtidas do câncer cervical de Henrietta Lacks;

- 6×His-tag: sequencia de resíduos de histidina;

- HPLC: cromatografia líquida de alta eficiência;

- IAA: iodoacetamida;

- IARC: Agência Internacional para Pesquisa em Câncer;

- ID: diâmetro interno;

- IgG: imunoglobulina G;

- INCA: Instituto Nacional de Câncer José Alencar Gomes da Silva;

- IPG: fita de gradiente de $\mathrm{pH}$ imobilizado;

- IPTG: isopropiltio- $\beta$-D-galactosídeo;

- kDA: kilo Daltons;

- LC-MS: cromatografia líquida acoplada à espectrometria de massas;

- MECQ: microbalança eletroquímica de cristal de quartzo; 
- MEV: Microscopia Eletrônica de Varredura;

- MLV: vesículas multi-lamelares

- MM: massa molecular;

- MPD: 2-metil-2,4-pentanediol;

- MS: espectrometria de massas;

- NCBI: National Center for Biotecnology Information;

- OCP: potencial de circuito aberto;

- OFFGEL: plataforma de focalização isoelétrica, Agilent Tachnologies;

- OMS: Organização Mundial da Saúde;

- OT: orbitrap ;

- pb: pares de bases;

- PBS: (Phosphate Buffered Saline) tampão fosfato salino;

- PBS-T: tampão fosfato salino com Tween-20;

- PCR: Reação em cadeia da polimerase;

- $\quad$ EET28a: Vetor de expressão em bactéria;

- pRSETaTF: Vetor de expressão pRSETa (Invitrogen) modificado com o DNA codificante da proteína Trigger factor;

- PFF: peptide fragmentation fingerprinting;

- pI: ponto isoelétrico;

- PMF: peptide mass fingerprinting;

- rpm: rotações por minuto;

- SDS-PAGE: gel de poliacrilamida em dodecil sulfato de sódio;

- SUV: pequenas vesículas unilamelares

- TAE: tampão tris-acetato-EDTA;

- TF: proteína Trigger factor;

- TFFR $\alpha$ : proteína recombinante FR $\alpha$ em fusão com a Trigger factor;

- YPD: meio de cultura de extrato de levedura, peptona e dextrose;

- YPDS: YPD sólido; 


\section{Sumário}

\section{Capítulo 1}

Câncer, Biomarcadores e Receptores de Folato ........................................................1

1 INTRODUÇÃ

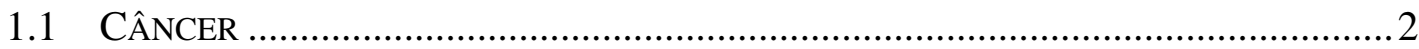

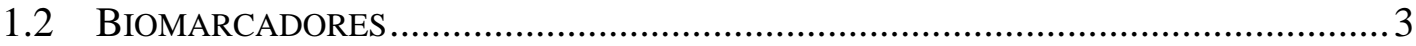

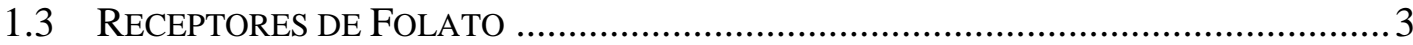

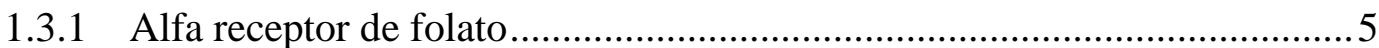

1.4 TÉCNICAS PARA ANÁLISE DE PROTEÍNAS ........................................................

1.4.1 Eletroforese Unidimensional (SDS-PAGE) ........................................ 9

1.4.2 Eletrotransferência de proteínas à membranas (Western Blot).................... 9

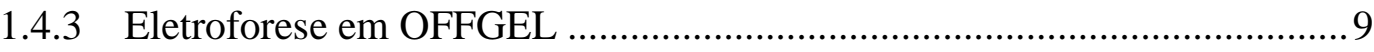

1.4.4 Espectrometria de Massas ...................................................................... 11

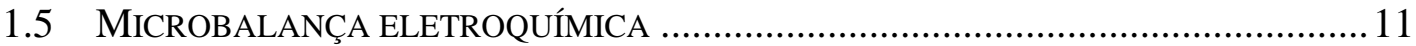

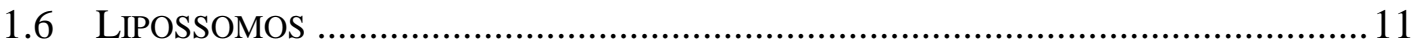

1.7 CARACTERIZAÇÃo MORfolÓGICA POR MiCROSCOPIA ….................................. 12

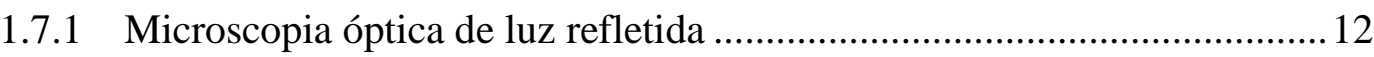

1.7.2 Microscopia de Força Atômica (MFA) ….............................................. 12

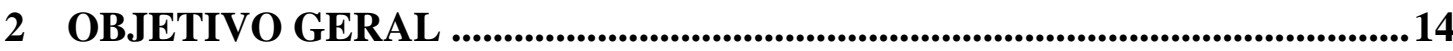

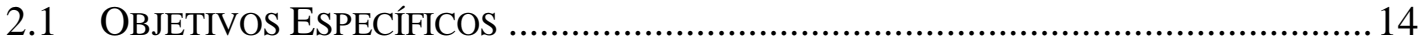

\section{Capítulo 2}

Clonagem, expressão e purificação da rFR $\alpha$ em E. coli ........................................15

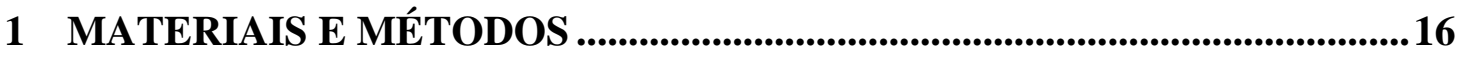

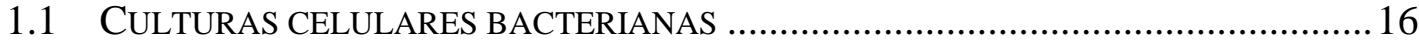

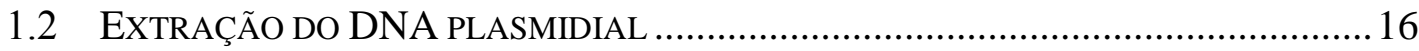

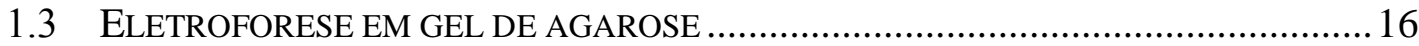

1.4 EXTRAÇÃO E PURIFICAÇÃO DE DNA A PARTIR DO GEL DE AGAROSE.................. 17

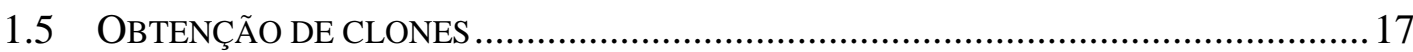

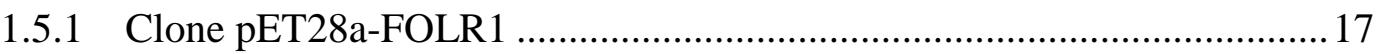

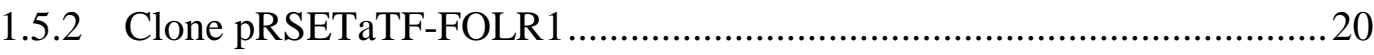


1.6 PREPARAÇÃO DE CÉLULAS E. COLI COMPETENTES …......................................25

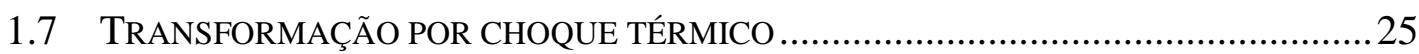

1.8 EXPRESSÃO DA PROTEÍNA RFRA EM E. COLI ................................................. 25

1.9 ENSAIO DE SOLUBILIDADE DA PROTEÍNA RECOMBINANTE..................................26

1.9.1 Purificação da proteína recombinante .....................................................2 27

1.10 TÉCNICAS PARA ANÁLISE E CONFIRMAÇÃO DE CLONAGEM ….........................22

1.10.1 Análise das colônias transformantes por PCR …...................................22

1.10.2 Análise de restrição enzimática .........................................................27

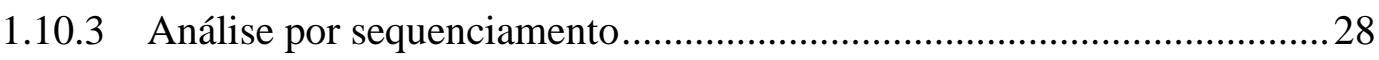

1.11 TÉCNICAS ANALÍTICAS PARA ANÁLISE E DETECÇÃO DE PROTEÍNAS..................22

1.11.1 Separação de proteínas por eletroforese SDS-PAGE..............................28

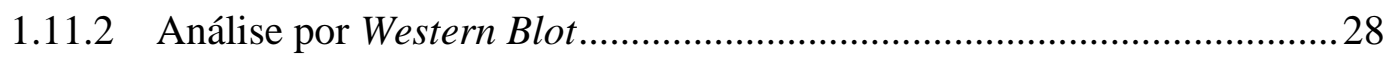

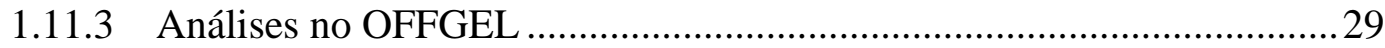

1.11.4 Análise de peptídeos por LC-MS/MS ................................................29

1.12 ENSAIO DE ATIVIDADE, PRODUÇÃO DE LIPOSSOMOS E ANÁLISES

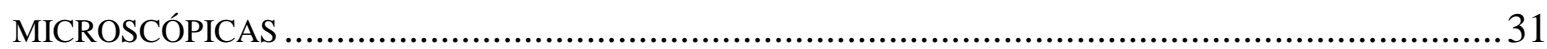

1.12.1 Ensaio de atividade em microbalança eletroquímica .............................. 32

1.12.2 Produção de lipossomos e imobilização da proteína recombinante .........32

1.12.3 Caracterização morfológica dos proteolipossomos ..................................34

2 RESULTADOS E DISCUSSÃO.......................................................................35

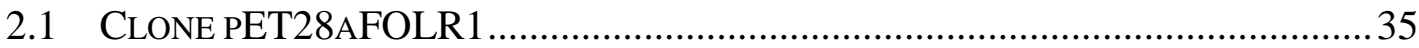

2.1.1 Ensaios de expressão e solubilidade da proteína rFR $\alpha$ em E. coli .............35

2.1.2 Ensaio de solubilidade da proteína recombinante FR $\alpha$ em E. coli .............36

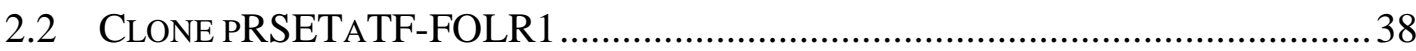

2.2.1 Amplificação do FOLR1 e clonagem no vetor modificado pRSETaTF ... 38

2.2.2 Expressão e ensaio de solubilidade da proteína recombinante TFFR $\alpha . . . .41$

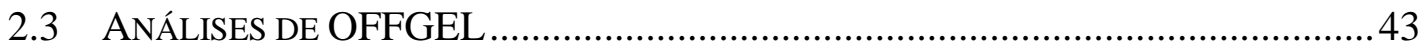

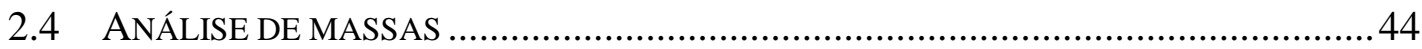

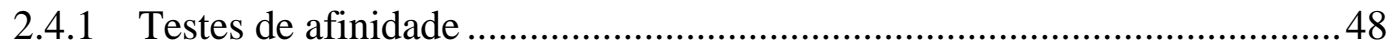

2.4.2 Testes de imobilização da TFFR $\alpha$ em lipossomo ......................................49

2.5 CARACTERIZAÇÃO MORFOLÓGICA DOS PROTEOLIPOSSOMOS ............................51

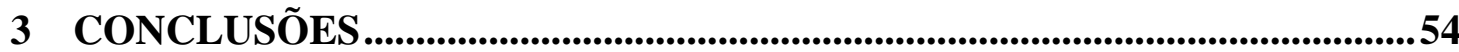




\section{Capítulo 3}

Clonagem, expressão e purificação da rFR $\alpha$ em P. pastoris 55

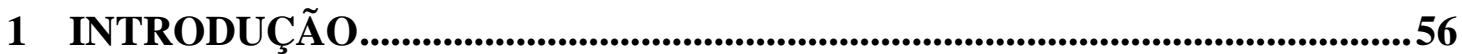

2 MATERIAIS E MÉTODOS ….........................................................................58

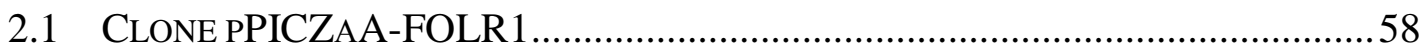

2.1.1 Propagação do plasmídeo recombinante pPICZaA-FOLR1 em E. coli DH5 $\quad 60$

2.1.2 Linearização do plasmídeo recombinante pPICZ $\alpha$ A-FOLR1 ....................60

2.2 PREPARAÇÃO DE P. PASTORIS KM71H ELETROCOMPETENTE ............................. 61

2.3 TRANSFORMAÇÃO COM PLASMÍDEO RECOMBINANTE PPICZAA-FOLR1 ...........61

2.4 ANÁLISE DA PRESENÇA DA REGIÃO CODIFICADORA DO GENE FOLR1 NO

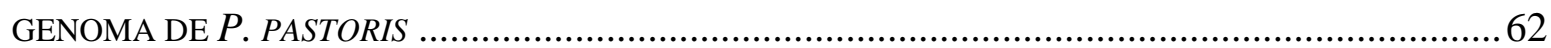

2.4.1 Isolamento do DNA genômico de P. pastoris........................................62

2.4.2 Análise das colônias transformantes por PCR .......................................62 62

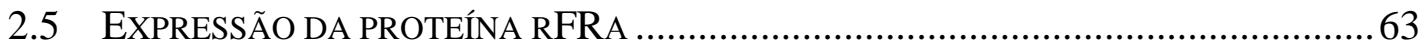

2.6 ENSAIO DE SOLUBILIDADE DA PROTEÍNA RECOMBINANTE .................................64

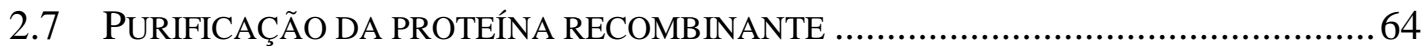

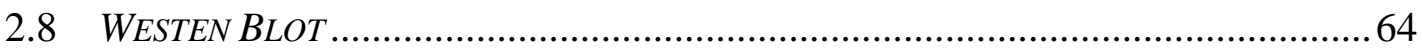

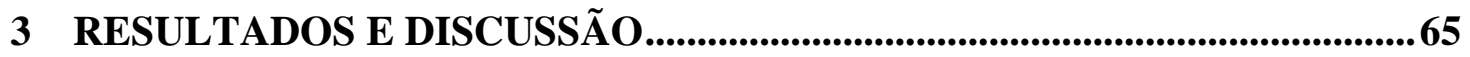

3.1 LINEARIZAÇÃO DO PLASMÍDEO PPICZ $\alpha A F O L R 1$ E TRANSFORMAÇÃO DA LINHAGEM KM71H DE P. PASTORIS .65

3.2 EXPRESSÃO E ENSAIO DE SOLUBILIDADE DA PROTEÍNA RECOMBINANTE RFRA EM P. PASTORIS 67

4 CONCLUSÕES 69

\section{Capítulo 4}

Conclusões Gerais e Perspectivas Futuras .70

Referências Bibliográficas . .73 


\section{Prefácio}

Optou-se por dividir esta dissertação em quatro capítulos. O Capítulo 1 apresenta uma revisão sobre o câncer, biomarcadores, receptores de folato e análises químicas, que foram a base para o desenvolvimento deste trabalho, além do objetivo geral da dissertação. Os Capítulos 2 e 3 foram divididos conforme o sistema de expressão utilizado, sendo que o Capítulo 2 versa sobre a expressão da proteína FR $\alpha$ em E. coli, enquanto o Capítulo 3 aborda a expressão da mesma no sistema eucarioto de $P$. pastoris. Finalmente, o Capítulo 4 apresenta uma conclusão geral do trabalho bem como perspectivas de trabalhos futuros. 


\section{Capítulo 1}

\section{Câncer, Biomarcadores e} Receptores de Folato 


\section{Introdução}

\subsection{Câncer}

De acordo com o Instituto Nacional de Câncer José Alencar Gomes da Silva (INCA), câncer é o nome dado a um conjunto de doenças que se caracterizam pelo crescimento agressivo e aleatório das células, podendo se transformar em metástases, ou seja, propagar-se para diferentes órgãos e tecidos. (1) Sua iniciação e progressão estão intrinsecamente relacionadas a erros genéticos ocorridos nos proto-oncogenes, inativos em células normais. Esses genes, responsáveis pelo controle da divisão celular ou mitose, quando ativados se transformam em oncogênese, levando a um crescimento celular aleatório. (1-3) A velocidade de multiplicação das células e a capacidade de invadir tecidos e órgãos vizinhos ou distantes, ocasionados pelo crescimento celular aleatório, são características de um processo conhecido como metástase, que diferencia os diversos tipos de câncer entre si, além de responder pela maior parcela de óbitos dentre as vítimas de câncer. (1)

Nos últimos anos a incidência do câncer tem crescido significativamente no mundo, atraindo cada vez mais a atenção para a doença. Segundo dados da Agência Internacional para Pesquisa em Câncer (International Agency for Research on Cancer, IARC), da Organização Mundial da Saúde (OMS), a estimativa é de aproximadamente 576 mil casos novos de câncer no Brasil para 2014 e o mesmo para 2015, e tende a aumentar no mundo todo em $75 \%$ até 2030, baseando-se em dados de 2008. (1,4) O contínuo crescimento populacional, bem como o aumento da expectativa e estilo de vida (associado à prevenção, à má alimentação, e ao sedentarismo), afetarão de forma significativa o crescimento do câncer no mundo. (1)

Além da necessidade de serem implementadas medidas preventivas para reduzir a incidência dos diversos tipos de câncer, como, por exemplo, o controle do tabagismo e a vacinação para hepatite, existe a necessidade do desenvolvimento de novos métodos de detecção precoce. (1) Atualmente, as técnicas empregadas para a detecção da doença não são individualmente conclusivas devido à subjetividade das análises, além de serem extremamente invasivas e não permitirem o diagnóstico precoce da doença. Sendo assim, o desenvolvimento de tecnologias alternativas para a detecção e o prognóstico da doença é plenamente justificado. (5) Com uma tecnologia alternativa, Lima et al. (2010) (2) relataram a possibilidade da utilização de biossensores para a detecção de biomarcadores em urina, 
sangue e outros fluidos biológicos, facilitando o diagnóstico da doença em termos de operação, custo e rapidez. (2)

\subsection{Biomarcadores}

De acordo com a FDA (Food and Drug Admnistration) biomarcadores são substâncias mensuráveis com características biológicas que indicam o estado normal ou doente de algum processo no corpo. (6,7) Existem relatos do conhecimento destas substâncias desde comunidades antigas tais como Arábica, Hindu e Chinesa, e hoje sabe-se que podem ser células, moléculas específicas, genes, enzimas ou hormônios, normalmente presentes em pequena quantidade em fluidos corporais e tecidos. (4)

As células cancerígenas podem produzir determinadas substâncias específicas que, quando encontradas em quantidade acima do normal, pode ser um indicativo da doença. Alguns exemplos de biomarcadores cancerígenos mais estudados são: CA 125 e 15.3 (relacionados à câncer de ovário e de mama), TRU-QUANT e 27.29 (câncer de mama), CEA (câncer de ovário, pulmão, mama, pâncreas e/ou trato gastrointestinal), CTC (células tumorais circulantes; indicativo de metástase) e PSA (próstata). (8)

\subsection{Receptores de Folato}

Receptores de folato (FR; vitamina B9) são biomarcadores extracelulares, representados por uma família de glicopolipeptídeos da membrana celular que transportam folato para o interior da célula. $(9,10)$

Folato é um termo genérico utilizado para o ácido fólico e compostos estruturalmente relacionados que possuem atividade bioquímica correlata, como por exemplo, folato reduzido, anti-folatos e conjugados de folato. Trata-se de um componente celular básico, envolvido essencialmente nas reações de transferência de carbono para a síntese de purinas e timina, importantes para a síntese e replicação do DNA, além de divisão, crescimento e sobrevivência celular, principalmente para células que se multiplicam rapidamente. (3) Atua na formação de produtos intermediários do metabolismo, que por sua vez estão envolvidos na formação 
celular. A aquisição do folato é essencial para a divisão celular rápida, e sua falta resulta em megaloblastose e morte prematura da célula. $(5,9)$ Atualmente, o ácido fólico é utilizado como suplemento alimentar, por conta da sua importância para a síntese e replicação do DNA, principalmente para mulheres que pretendem engravidar, e nos primeiros meses de gestação. Porém, estudos envolvendo receptores de folato recomendam atenção para esta suplementação no caso de pacientes com câncer. (11)

Estrutura química do ácido fólico.

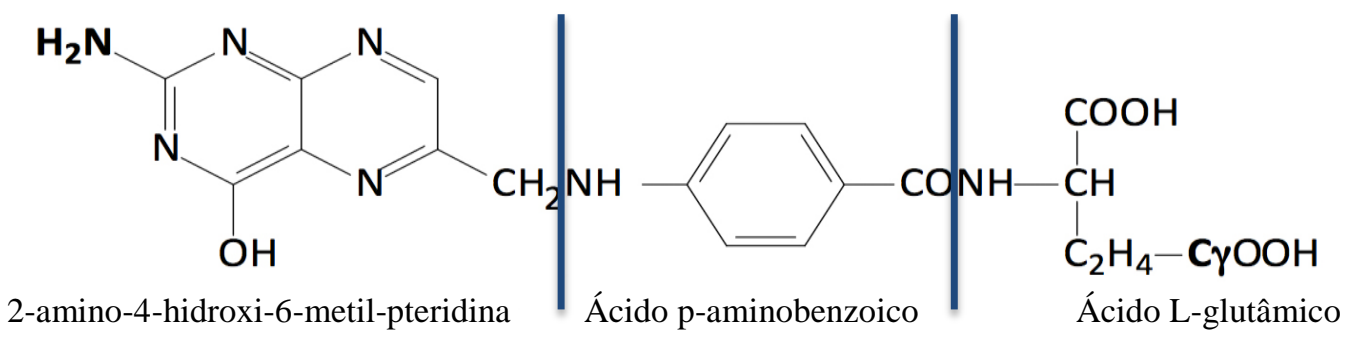

Fonte: Adaptação de MIRANDA (2014) a partir de LIMA, R.S, 2010, $138 f$.

Os receptores de folato atuam em um dos vários mecanismos responsáveis pelo transporte de folato que acontecem no corpo. (12) Pesquisas sobre o genoma humano revelaram a existência de uma família multigene FOLR (FOLR1, FOLR2, FOLR3) localizada no cromossomo 11 (q13.3-q14.1) que codifica, respectivamente as isoformas FR $\alpha, \beta$ e $\gamma$. Tratam-se de sequências altamente conservadas compartilhando de 71 a $79 \%$ da mesma sequência, com oito ligações dissulfeto, as quais possuem de 220 a 239 aminoácidos. $(3,13)$ São formadas interações altamente especificas entre FR e ácido fólico (FA), via grupo amino $\left(-\mathrm{NH}_{2}\right)$ da 6-metilpterina do ligante, com alta afinidade da ordem de $10^{9}-10^{10} \mathrm{nM}$. $(3,14)$

Contudo, esta homologia não implica em uma correspondência nos padrões de distribuição em tecidos, função ou regulação. (12) Ao contrário, podem se diferenciar no tecido em que são expressas, na função exercida ou nas propriedades bioquímicas. (15) As isoformas $\alpha$ e $\beta$ são as mais comuns nas células e ambas são ligadas ao lado externo da membrana citoplasmática através da ligação de uma unidade glicosil fosfatidil inusitol (GPI). Essa modificação pós-traducional, que acontece no complexo de Golgi, permite que toda a 
proteína fique situada no espaço extracelular, exceto a âncora, não interferindo na ligação com o folato. $(12,16)$ A FR $\gamma$, por outro lado, é uma proteína secretada já que não apresenta sinais de modificação GPI. Contudo, formas solúveis extracelulares de FR $\alpha$ e FR $\beta$ podem ser produzidas através da ação de proteases e fosfolipases de membrana ou intracelulares. (12)

\subsubsection{Alfa receptor de folato}

Alfa receptores de folato $(\mathrm{FR} \alpha)$ são proteínas extracelulares de 239 resíduos de aminoácidos (Figuras 2 e 3), com 8 pontes dissulfeto e três sítios de N-glicosilações. A correta ligação entre as 16 cisteínas presentes na molécula é importante para eventual ligação com o folato, contudo as glicosilações são necessárias para a atividade de internalização do ligante. $(9,16,17)$ Esses receptores possuem propriedades bioquímicas específicas, que podem ser exploradas pela estratégia de marcação para detecção e tratamento do câncer. Com raras exceções, FR $\alpha$ são induzidos seletivamente em tecidos cancerígenos e raramente expresso em células normais, mostrando-se, assim, altamente sensíveis e específicos, demostrado seu potencial como biomarcador para determinados cânceres. As variações na expressão do FR $\alpha$ foram observadas em mesotelioma (18), cânceres ginecológicos $(11,14,19-21)$, carcinomas de tecidos pancreáticos e de bexiga (20), colorretal (22), pulmão (20,23-25), pâncreas e rim (20) entre outros. 
Figura 1 - Sequências nucleotídica e de aminoácidos e da Proteína FR $\alpha$ de Homo sapiens. Em amarelo esta destacada a sequência do peptídeo sinal

>gi|262331569|ref|NM_016729.2I Homo sapiens folate receptor 1 (adult)

(FOLR1), transcript variant 4, mRNA

CATTCCTTGGTGCCACTGACCACAGCTCTTTCTTCAGGGACAGACATGGCTCAGCGGATGACAACACAGC TGCTGCTCCTTCTAGTGTGGGTGGCTGTAGTAGGGGAGGCTCAGACAAGGATTGCATGGGCCAGGACTGA GCTTCTCAATGTCTGCATGAACGCCAAGCACCACAAGGAAAAGCCAGGCCCCGAGGACAAGTTGCATGAG CAGTGTCGACCCTGGAGGAAGAATGCCTGCTGTTCTACCAACACCAGCCAGGAAGCCCATAAGGATGTTT CCTACCTATATAGATTCAACTGGAACCACTGTGGAGAGATGGCACCTGCCTGCAAACGGCATTTCATCCA GGACACCTGCCTCTACGAGTGCTCCCCCAACTTGGGGCCCTGGATCCAGCAGGTGGATCAGAGCTGGCGC AAAGAGCGGGTACTGAACGTGCCCCTGTGCAAAGAGGACTGTGAGCAATGGTGGGAAGATTGTCGCACCT CCTACACCTGCAAGAGCAACTGGCACAAGGGCTGGAACTGGACTTCAGGGTTTAACAAGTGCGCAGTGGG AGCTGCCTGCCAACCTTTCCATTTCTACTTCCCCACACCCACTGTTCTGTGCAATGAAATCTGGACTCAC TCCTACAAGGTCAGCAACTACAGCCGAGGGAGTGGCCGCTGCATCCAGATGTGGTTCGACCCAGCCCAGG GCAACCCCAATGAGGAGGTGGCGAGGTTCTATGCTGCAGCCATGAGTGGGGCTGGGCCCTGGGCAGCCTG GCCTTTCCTGCTTAGCCTGGCCCTAATGCTGCTGTGGCTGCTCAGCTGACCTCCTTTTACCTTCTGATAC CTGGAAATCCCTGCCCTGTTCAGCCCCACAGCTCCCAACTATTTGGTTCCTGCTCCATGGTCGGGCCTCT GACAGCCACTTTGAATAAACCAGACACCGCACATGTGTCTTGAGAATTATTTGGAAAAAAAAAAAAAAAA AA

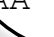

>gi|9257213|ref|NP_057941.1| folate receptor alpha precursor [Homo sapiens] MAQRMTTQLLLLLVWVAVVGEAQTRIAWARTELLNVCMNAKHHKEKPGPEDKLHEQCRPWRKNACCSTNT SQEAHKDVSYLYRFNWNHCGEMAPACKRHF IQDTCLYECSPNLGPWIQQVDQSWRKERVLNVPLCKEDCE QWWEDCRTSYTCKSNWHKGWNWTSGFNKCAVGAACQPFHFYFPTPTVLCNEIWTHSYKVSNYSRGSGRCI QMWFDPAQGNPNEEVARFYAAAMSGAGPWAAWPFLLSLALMLLWLLS

Fonte: NATIONAL CENTER FOR BIOTECHNOLOGY, 2014.

Alguns autores citam o desenvolvimento de inibidores do FR $\alpha$ e até ligantes alvo, para a entrega seletiva de agentes de imagens e terapêuticos. Esse é o caso de Vaitilingam et al. (2012) (5), que relataram o desenvolvimento das formas reduzida e alquilada do ácido fólico, $\mathrm{N}^{5}, \mathrm{~N}^{10}$-dimetil tetrahidrofolato (DMTHF), um ligante alvo que apresentou seletividade para FR $\alpha$.

Trabalhos mais recentes relataram a elucidação da estrutura cristalina da isoforma $\alpha$ deste receptor complexado com o seu ligante e anti-ligantes. $(17,26)$ Chen et al. (2013) descreveram a estrutura da proteína humana, em que propuseram uma estrutura globular à FR $\alpha$ estabilizada por 8 ligações dissulfeto, contendo um bolsão com o sítio de ligação ao 
folato. (26) Wibowo et al. (2013) construíram modelos cristalográficos que contribuíram para a elucidação dos mecanismos de internalização de folato, além das características da ligação de folatos e anti-folatos à este receptor, incentivando o desenvolvimento de novas drogas que o tenham como alvo. Ainda, seus estudos sobre a dependência do $\mathrm{pH}$ do meio e os mecanismos de ligação e liberação do folato corroboraram com estudos anteriores, mostrando que ocorrem, respectivamente, nos meios extra celular $(\mathrm{pH} \sim 7,0-7,4)$ e endossomal ( $\mathrm{pH}$ $\sim 5,0-6,5) .(26)$

Figura 2 - Representação estrutural da proteína FR $\alpha$; extremidades N- (azul) e C-terminal (vermelho). Coordenadas da proteína 4RLH do Protein Data Bank.

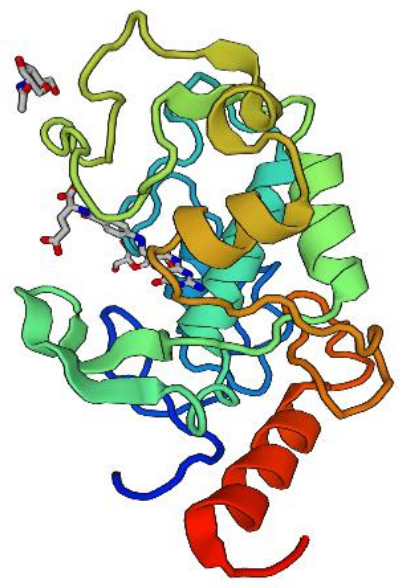

Fonte: CHEN, C.; et al. Nature, v. 500, n. 7463, p. 486-9, 2013.

Sendo assim, a liberação da forma solúvel de FR $\alpha$ na corrente sanguínea pode proporcionar uma maneira de controle da expressão deste receptor na superfície das células, sendo um potencial marcador para os tumores FR $\alpha$ positivos, já que sua quantidade solúvel é reduzida ou não detectável em condições normais. (3)

Tendo em vista a elucidação da estrutura deste receptor e de sua ligação com determinados ligantes, novas linhas de trabalhos são abertas, principalmente no que se diz respeito ao desenvolvimento de novas drogas anti-cancerígenas. Desta forma, neste trabalho procurou-se, com o auxílio de técnicas moleculares, produzir o alfa receptor de folato 
recombinante (rFRa) para subsequente imobilização em partículas, produzindo um arranjo biomimético de uma célula tumoral circulante, útil para o desenvolvimento de determinados biodetectores. Deve ser ressaltado que este estudo foi iniciado antes dos avanços hoje conhecidos, relatados por Chen et al. (2013) e Wibowo et al. (2013), que dizem respeito à estrutura do FR $\alpha$.

Desde o advento da tecnologia do DNA recombinante, a expressão de proteínas recombinantes no sistema de bactérias é utilizado, principalmente por sua simplicidade e o conhecimento já adquirido. Entre outras vantagens, a rapidez para a obtenção de proteínas e a rápida acumulação de biomassa devem sem ressaltadas.

Avanços tecnológicos possibilitam a expressão de proteínas eucarióticas, como por exemplo a insulina, facilitando e barateando o custo de produção das mesmas, podendo ser produzidas em grande escala. Em especial, a expressão da proteína recombinante em fusão com diferentes caudas facilita a detecção e a purificação, diminuindo etapas no processo como um todo. Contudo, sistemas de expressão alternativos têm se destacado, principalmente, por conta do sistema bacteriano não incluir modificações pós-traducionais e nem sempre proporcionarem à proteína recombinante um ambiente propício ao enovelamento correto, dando origem aos corpos de inclusão. Mesmo assim, trata-se de uma ferramenta com grande potencial, importante nos estudos de estrutura, função e identificação de proteínas em geral.

\subsection{Técnicas para análise de proteínas}

A técnica mais utilizada para análise de misturas proteicas complexas, como em um experimento de expressão heteróloga é a eletroforese unidimensional em gel de poliacrilamida (1-DE ou SDS-PAGE). (27) Contudo, dentre outras técnicas existentes (2-DE, HPLC, entre outras), neste trabalho foram empregados a cromatografia de afinidade, o Western Blot, o fracionamento de proteínas por OFFGEL (Agilent Tecnhologies), além de cromatografia líquida acoplada à espectrometria de massa/massa (LC-MS/MS), que envolveram a SDSPAGE em alguma etapa. 


\subsubsection{Eletroforese Unidimensional (SDS-PAGE)}

A eletroforese unimensional em gel de poliacrilamida (PAGE; polyacrylamide gel electrophoresis) é uma técnica de separação largamente utilizada para análises do conteúdo de misturas proteicas, principalmente por sua rapidez, baixo custo e reprodutibilidade. $\mathrm{O}$ agente tensoativo aniônico dodecil sulfato de sódio (SDS) é adicionado na etapa de preparação do gel de poliacrilamida para a desnaturação das proteínas, além de proporcionar a formação de complexos proteína-detergente, o que anula a carga intrínseca das proteínas. (27) Desta forma, a separação ocorre de acordo com suas respectivas massas moleculares (MM), as quais podem ser estimadas através da comparação de suas mobilidades eletroforéticas com a de proteínas de MM conhecidas, utilizadas como padrão. O protocolo utilizado para este método foi o Laemmli, contendo um gel de empilhamento e outro de corrida. (27)

\subsubsection{Eletrotransferência de proteínas à membranas (Western Blot)}

Esta é uma técnica que possibilita a imobilização de proteínas em uma membrana de nitrocelulose (NC), favorecendo o acesso de reagentes para detecção de proteínas. Utiliza-se, neste processo, anticorpos da proteína de interesse e um passo de sinalização que possibilita a detecção. Um exemplo de construção que possibilita a detecção é a expressão de uma proteína recombinante em fusão com uma $6 \times$ His-tag, uma vez que o anticorpo anti His-tag revela a existência ou não da proteína em fusão nas amostras transferidas, com o auxílio de sondas ou anticorpos secundários. (27)

\subsubsection{Eletroforese em OFFGEL}

Esta técnica foi utilizada para separação de uma amostra de proteínas para detectar aquelas que partilhavam da mesmas massas porém se diferenciavam pelos respectivos pontos isoelétricos (pI). A focalização isoelétrica de proteínas em solução ocorre através de uma fita 
de gel com gradiente de $\mathrm{pH}$ imobilizado (IPG), em que a amostra é fracionada em solução de acordo com a faixa de $\mathrm{pH}$.

Para a focalização isoelétrica através da plataforma denominada OFFGEL Fractionator, Agilent Tachnologies, a amostra é diluída em tampão de focalização e igualmente depositada em compartimentos instalados sobre fita IPG. A ausência de conexões fluídicas entre os reservatórios induz a migração das proteínas presentes na amostra através do gel para o poço cujo $\mathrm{pH}$ seja próximo ao seu pI, sendo recuperadas em fase líquida, como mostra o esquema da Figura 4. (28)

Figura 3 - Esquema do processo de fracionamento de proteínas por OFFGEL (Agilent Tecnhologies).

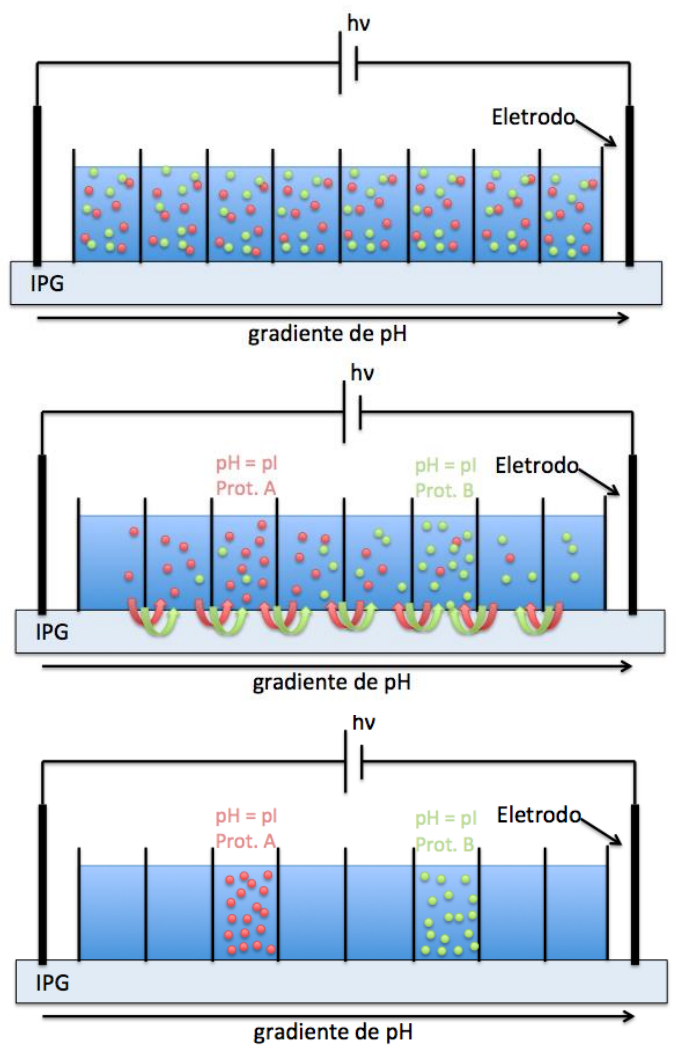

Fonte: Adaptação de Miranda (2014) a partir de PRECKEL, T, 2007. p 1-2. 


\subsubsection{Espectrometria de Massas}

Trata-se de uma técnica poderosa que permite a determinação da massa molecular de proteínas e a sequência de aminoácidos através da análise de seus peptídeos. A identificação das proteínas ocorre por meio da comparação dos dados obtidos com bancos de dados de sequências de aminoácidos, peptídeos e proteínas, permitindo também caracterizar possíveis modificações pós-traducionais. Uma das plataformas utilizadas para identificação de proteínas com alta precisão e resolução é a espectrometria de massas com ionização por electrospray.

\subsection{Microbalança eletroquímica}

Testes com Microbalança Eletroquímica de Cristal de Quartzo (MECQ), são promovidos para diversas aplicações como o desenvolvimento de biossensores, reação de estudo de afinidade, associação e dissociação, além da determinação constantes cinéticas entre outras.

Esta tecnologia, acoplada a um potenciostato/galvanostato e com a utilização de um eletrodo de trabalho possibilita a análise da variação de massa, $\Delta m$, através da conversão da variação de frequência, $\Delta f$, de acordo com a equação de Sauerbrey, onde:

$$
\Delta f=-k_{f} \Delta m
$$

$k_{f}$ é a constante de sensibilidade do cristal de quartzo $\left(0,056 \mathrm{~Hz} \mathrm{ng}^{-1} \mathrm{~cm}^{2}\right)$. (29)

\subsection{Lipossomos}

Membranas biológicas são extremamente complexas, atuando como barreiras para permeação seletiva, tipicamente compostas por uma dupla camada de fosfolipídeos, proteínas e outras moléculas, além de possuírem funções específicas. Processos que envolvem a membrana celular são: transporte, comunicação celular, fusão de membranas, entre outros. Tratando-se de barreiras celulares, estas devem ser porosas porém robustas, além de flexíveis. 
Diferentes tecnologias já foram desenvolvidas para o estudo e produção de membranas biomiméticas, sendo os lipossomos utilizados para inúmeras aplicações científicas e tecnológicas principalmente por sua semelhança com as membranas biológicas, tendo os fosfolipídeos como os componentes mais importantes. Ultimamente esta construção tem sido utilizada para entrega controlada de medicamentos, principalmente devido à sua biocompatibilidade. $(30,31)$

Outra tecnologia utilizada para o estudo de membranas biológicas utiliza as "vesículas gigantes unilamelares" (GUVs, giant unilamelar vesicles). As GUVs são especialmente úteis para o estudo das propriedades físicas de membranas celulares e, para isso, a fabricação destas vesículas é um fator importante. Uma vez que os métodos convencionais de produção de lipossomos limitam o estudo dessas membranas por produzirem vesículas polidispersas em tamanho e composição lipídica, Arriaga et al. desenvolveram uma metodologia microfluídica de produção que se destaca pela produção de GUVs de tamanho e composições uniformes. (32)

\subsection{Caracterização Morfológica por Microscopia}

\subsubsection{Microscopia óptica de luz refletida}

Sendo o microscópio óptico um dos equipamentos mais versáteis utilizados em estudos laboratoriais, houve a necessidade de evolução da técnica que possibilitasse um aumento no grau de automação. Assim surgiu a microscopia digital que, nos equipamentos mais modernos, possibilita o controle digital de praticamente todas suas funções, como autofoco, definição de plano de foco, correção de imagens, varredura da amostra e aquisição automática de imagens, entre outras.

\subsubsection{Microscopia de Força Atômica (MFA)}

A microscopia de força atômica é um tipo de microscopia de varredura por sonda que possibilita a aquisição de imagens de superfícies de diferentes materiais, incluindo amostras biológicas. Atualmente as análises são promovidas através de uma pequena sonda e um 
cantilever microfabricados de $\mathrm{SiO}_{2}$ ou $\mathrm{Si}_{3} \mathrm{~N}_{4}$, que capturam a imagem tridimensional da superfície de amostra. Um laser é utilizado para induzir a deflecção da sonda sob a amostra, e um detector analisa as oscilações, amplitudes ou frequências, promovidas por interações entre a amostra e a sonda. Modos de operações diferentes possibilitam a análise em contato com a amostra e, também, não-contato. Em comparação com a Microscopia Eletrônica de Varredura (MEV), este tipo de microscopia se destaca por possibilitar a análise de materiais isolantes sem que haja a necessidade de preparo de amostra com metalização ou revestimento de carbono, além do curto tempo de análise. (33) 


\section{Objetivo Geral}

Expressar heterologamente a proteína FRa para subsequente imobilização em partículas poliméricas ou lipossômicas, produzindo um arranjo biomimético de uma célula tumoral circulante para ser usado como padrão analítico para estudos com o biodetector de alfa receptores de folato.

\subsection{Objetivos Específicos}

- Desenhar primers (oliginucleotídeo) para amplificação do DNA codificante (FOLR1) da proteína FR $\alpha$, através de reação em cadeia da polimerase (PCR).

- Clonar genes em vetor de expressão;

- Expressar em larga escala a proteína FR $\alpha$;

- Otimizar o protocolo para a super-expressão da proteína FR $\alpha$, de forma solúvel e ativa;

- Purificar a proteína recombinante por cromatografia preparativa;

- Imobilizar os receptores em microssistemas, produzindo um arranjo biomimético de uma célula tumoral circulante. 


\section{Capítulo 2}

\section{Clonagem, expressão e}

puríficação da $r \mathcal{F} R \alpha$ em $\mathcal{E}$. col 


\section{$1 \quad$ Materiais e Métodos}

\subsection{Culturas celulares bacterianas}

Linhagens de Escherichia coli (E. coli) DH5 e DH10 $\beta$ foram utilizadas para a clonagem e propagação dos plasmídeos. Para ensaios dos padrões de expressão foram utilizadas as linhagens de E. coli BL21(DE3) e BL21(DE3) RIL. Testes de expressão também foram promovidos com as linhagens da mesma bactéria BL21(DE3)pTGROE e Rosetta(DE3).

As células transformadas foram cultivadas em meio sólido seletivo em placas de Luria-Betani-agár $(1 \%(\mathrm{~m} / \mathrm{m})$ Triptona, $0,5 \%(\mathrm{~m} / \mathrm{m})$ extrato de levedura, $1 \%(\mathrm{~m} / \mathrm{m}) \mathrm{NaCl}$ e 1,5\% (m/m) ágar), overnight, a $37{ }^{\circ} \mathrm{C}$. Colônias transformantes foram cultivadas em meio líquido LB $(1 \%(\mathrm{~m} / \mathrm{m})$ Triptona, $0,5 \%(\mathrm{~m} / \mathrm{m})$ extrato de levedura e $1 \%(\mathrm{~m} / \mathrm{m}) \mathrm{NaCl})$ seletivo, overnight, a $37{ }^{\circ} \mathrm{C}$, em incubadora com agitação orbital (250 rpm). As células bacterianas foram armazenadas a $-80{ }^{\circ} \mathrm{C}$ em glicerol $30 \%(\mathrm{v} / \mathrm{v})$.

\subsection{Extração do DNA plasmidial}

O DNA plasmidial foi extraído de células transformantes após crescimento overnight a $37^{\circ} \mathrm{C}$, em $5 \mathrm{~mL}$ de meio LB seletivo, através do método de lise alcalina com o Wizard ${ }^{\circ}$ Plus SV Minipreps DNA Purification Systems (Promega), de acordo com as instruções do fabricante.

\subsection{Eletroforese em gel de agarose}

As amostras de DNA foram preparadas em tampão de amostra (BioRad) e submetidas à eletroforese em gel de agarose $1 \%(\mathrm{~m} / \mathrm{v})$ em TAE $1 \times\left(\right.$ EDTA $1 \mathrm{~mol} \mathrm{~L}{ }^{-1}$, TRIS $40 \mathrm{~mol} \mathrm{~L}^{-1}$, ácido acético $\left.20 \mathrm{~mol} \mathrm{~L}^{-1}, \mathrm{pH} 8,5\right)$ com $1 \mathrm{mg} \mathrm{mL}^{-1}$ de brometo de etídeo. As análises foram feitas em cuba de eletroforese horizontal a $100 \mathrm{~V}$ em tampão TAE 1×. O gel foi posteriormente fotodocumentado utilizando-se o equipamento Image Quant LAS 4000 (GE Healthcare), sob luz ultravioleta (365 nm). 


\subsection{Extração e purificação de DNA a partir do gel de agarose}

As bandas de interesse referentes aos DNAs amplificados a partir de PCR ou aqueles tratados enzimaticamente foram purificados com o kit Wizard SV Gel clean-up System (Promega), de acordo com as recomendações do fabricante. Os DNAs plasmidiais foram quantificados com a leitura de absorbância a $260 \mathrm{~nm}$ em equipamento Nanodrop (Thermo Scientific).

\subsection{Obtenção de clones}

Durante o desenvolvimento do trabalho foram produzidos diferentes clones, de acordo com as possibilidades e necessidades que surgiram, sendo que nem todos estão aqui descritos, somente as construções que se mostraram mais promissoras. Em todas as construções objetivou-se a clonagem do DNA FOLR1, que codifica a expressão da proteína FR $\alpha$ de Homo sapiens, incluindo os aminoácidos 23 até 257 (número baseado nas sequências NP_000793.1, NP_057936.1, NP_057937.1, NP_057941.1 depositadas no banco de dados NCBI, National Center for Biotecnology Information), sendo retirado desta sequência o peptídeo sinal da sequência nativa (Figura 2).

\subsubsection{Clone pET28a-FOLR1}

Foram adquiridos clones prontos pET28a-FOLR1 (Epoch BioLabs Inc.) como alternativa às tentativas iniciais de clonagem, para serem iniciadas as etapas de transformação e expressão da rFR $\alpha$, esquematizado na Figura 5. 
Figura 4 - Mapa do vetor de expressão pET28a clonado com o fragmento FOLR1 entre os sítios de restrição das endonucleases NdeI e XhoI. Esta construção possibilita a expressão da proteína FR $\alpha$ recombinante em fusão com $6 \times$ His-tag na porção N-terminal da proteína, após um sítio de trombina.

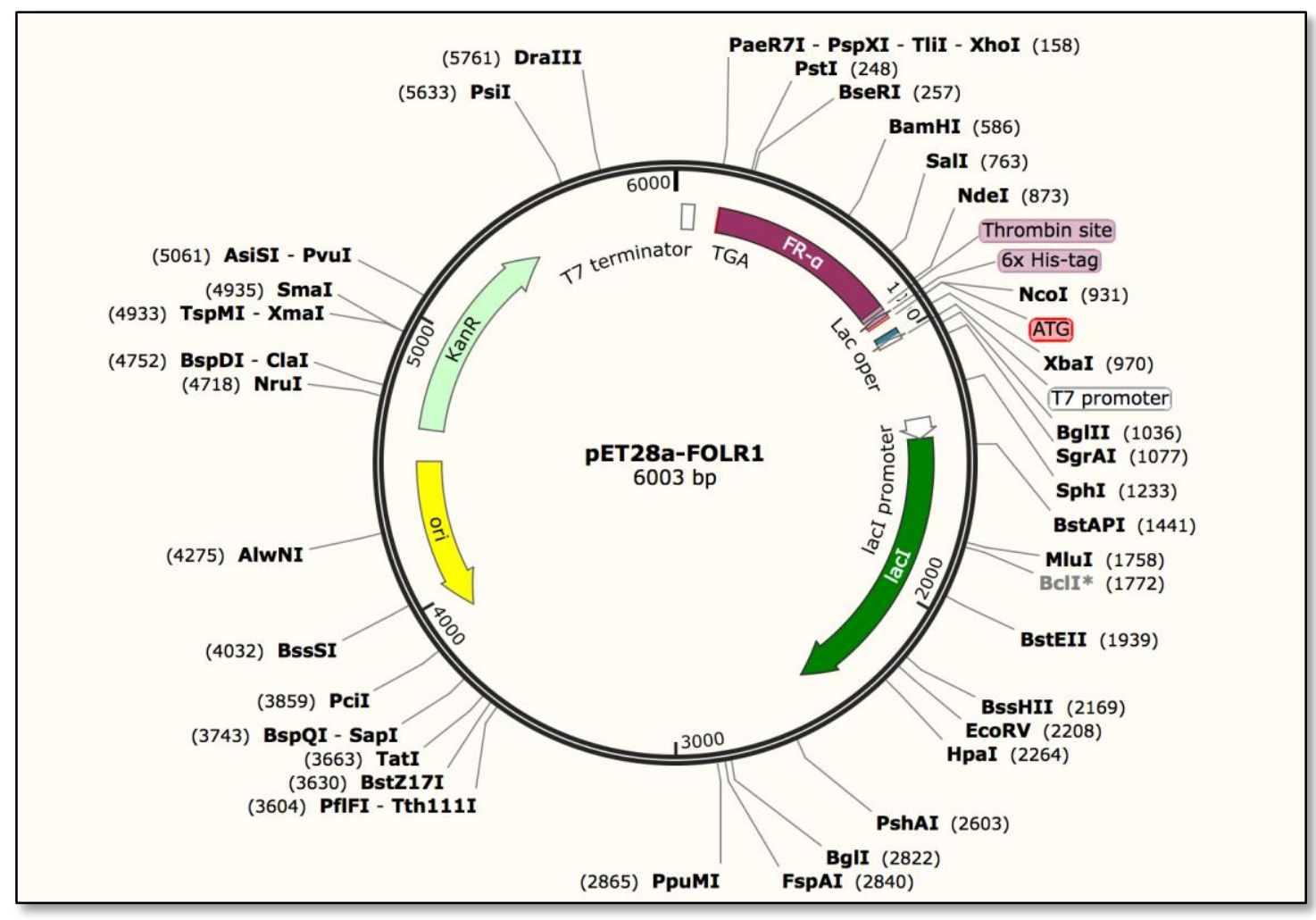

$$
\begin{aligned}
& 5^{\prime} \text { atccggatatagt tcctcctt tcagcaaaaaccctcaagacccgtt tagaggcccaaggggt tatgctagt tattgctcagcggtgg } \\
& \text { taggcctatatcaaggaggaagtcgtttttggggagttctgggcaatctccggggttcccaatacgatcaataacgagtcgccacc } \\
& \text { T7 terminator } \\
& \text { Tlir }_{\text {XhoI }} \\
& \begin{array}{l}
\text { XhoI } \\
\text { PspXI } \\
\text { PaeR7I }
\end{array} \\
& \text { cagcagccaactcagcttcctttcgggctttgttagcagccggatctcagtggtggtggtggtggtgctcgagtcagctgagcagccaca } \\
& \text { gtcgtcggttgagtcgaaggaagcccgaacaatcgtcggctagagtcaccaccaccaccaccacgagctcagtcgactcgtcggtgt } \\
& \underbrace{\frac{1}{1} \text { Ser Leu Leu TrP Leu }}_{\text {TGA }} \\
& \text { PstI BserI }
\end{aligned}
$$


cattgggttgccetgggctgggtcgaaccacatctggatgcagcggccactccctcggctgtagttgctgaccttgtaggagtgagtcc gtaacccaacgggacccgacccagcttggtgtagacctacgtcgccggtgagggagccgacatcaacgactggaacatcctcactcagg Asn Pro Asn Gly Gin Ala Pro Asp Phe Trp Met Gln Ile Cys Arg Gly Ser Gly Arg Ser Tyr Asn Ser Val Lys Tyr Ser His Thr Trp

agat t tcat tgcacagaacagtgggtgtggggaagtagaaatggaaaggt tggcaggcagctccactgcgcact tgt taaaccctgaag tctaaagtaacgtgtcttgtcacccacacccttcatctttacctttccaaccgtccgtcgagggtgacgcgtgaacaattgggacttc Ile Glu Asn Cys Leu Val Thr Pro Thr Pro Phe Tyr Phe His Phe Pro Gln Cys Ala Ala Gly Val Ala Cys Lys Asn Phe Gly Ser Thr
(in frame with 6x His-tag) (in frame with 6x His-tag)

tccagt tccagccttgtgccagt tgctcttgcaggtgtaggaggtgcgacaatct tcccaccat tgctcacagtcctctt tgcacaggg aggtcaaggtcgggaacacggtcaacgagacgtccacatcctccacgctgttagaaggtggtaacgagtgtcaggagaacgtgtccc Trp Asn Trp Gly Lys His Trp Asn Ser Lys Cys Thr Tyr Ser Thr Arg Cys Asp Glu Trp Trp Gln Glu Cys Asp Glu Lys Cys Leu Pro

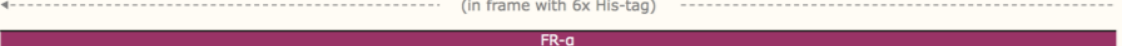

BamHI

gcacgt tcagtaccegctctt tgcgccagctctgatccacctgctggatccagggcccaagttggggagcactcgtagaggcaggtgt

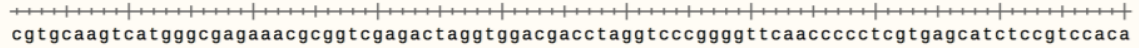

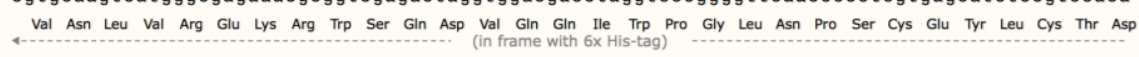
FR-a

cctggatgaaatgccgtttgcaggcaggtgccatctctccacagtggttccagttgaatctatataggtaggaaacatccttatgggctt ggacctactt tacggcaacgtccgtccacggtagagaggtgtcaccaaggtcaact tagatatatccatcctt Gin Ile Phe His Arg Lys Cys Ala Pro Ala Met Glu Gly Cys His Asn Trp Asn Phe Arg Tyr Leu Tyr Ser Val Asp Lys His Ala Glu
(in frame with 6x His-tag) FR-a

SalI

cctggctggtgttggtagaacagcaggcattcttcctccagggtcgacactgctcatgcaacttgtcctcggggcctggcttttccttgt ggaccgaccacaaccatcttgtcgtccgtaagaaggaggtccagctgtgacgagtacgttgaacaggagcccogaccgaaaggaaca Gin Ser Thr Asn Thr Ser Cys Cys Ala Asn Lys Arg Trp Pro Arg Cys Gin Glu His Leu Lys Asp Glu Pro Gly Pro Lys Glu Lys His 4in Ser Thr Asn Thr Ser Cys Cys Ala Asn Lys Arg Trp Pro Arg Cys Gln Glu His Leu Lys Asp Glu Pro Gly Pro Lys Glu Lys His

\section{NdeI}

ggtgct tggcgttcatgcagacat tgagaagctcagtcctggcccatgcaatccttgtctgcatatggctgccgcgcggcaccaggccgc ccacgaaccgcaagtacgtctgtaactcttcgagtcaggaccggtacgt taggaacagacgtataccgacggcgcgcegtggtccggcg His Lys Ala Asn Met Cys Val Asn Leu Leu Glu Thr Arg Ala Trp Ala Ile Arg Thr Gln Met His Ser Gly Arg Pro Val Leu Gly Ser FR-a

NcoI

XbaI

tgctgtgatgatgatgatgatggctgctgcccatggtatatctccttcttaaagt taaacaaaat tat tctagagggaattgttatcc acgacactactactactactaccgacgacgggtaccatatagaggaagaatt tcaattgtttaataagatctcccttaacaatagg Ser His His His His His His Ser Ser Gly Met

gctcacaat tccctatagtgagtcgtat taat t tcgcgggatcgagatctcgatcctctacgccggacgcatcgtggccggcatcaccg cgagtgt taagggatatcactcagcataat taaagegecctagctctagagetaggagatgeggectgegtagcaceggcegtagtgge Lac oper

Fonte: Autoria própria com auxílio do software SnapGene. 


\subsubsection{Clone pRSETaTF-FOLR1}

Este clone foi construído a partir da amplificação do fragmento FOLR1 presente no clone pPICZaA-FOLR1 (Epoch Biolabs, Inc.), e o vetor pRSETa previamente modificado pelo prof. Dr. Gerhard Wunderlich.

\subsubsection{Amplificação do gene FOLR1}

Para a reação em cadeia da polimerase (PCR), o clone pPICZalphaA-FOLR1 foi utilizado como DNA molde, e os primers (Boston Open Lab) utilizados estão descritos na Tabela 1. As condições da PCR foram otimizadas, chegando a uma reação-padrão contendo 0,3 $\mu \mathrm{L}$ de Taq DNA Polimerase (5 U/ $\mu \mathrm{L}$, Fermentas); $1,5 \mu \mathrm{L}$ de $\mathrm{MgCl}_{2}\left(25 \mathrm{mmol} \mathrm{L}^{-1}\right) ; 1,5 \mu \mathrm{L}$ de Tampão 10× (Taq Buffer Fermentas); 0,15 $\mu \mathrm{L}$ Primer $R ; 0,15 \mu \mathrm{L}$ Primer $F ; 0,4 \mu \mathrm{L}$ de dNTP $\left(10 \mathrm{mmol} \mathrm{L}^{-1}\right)$, e $0,2 \mu \mathrm{L}$ de DNA molde. O protocolo teve início com um ciclo de $30 \mathrm{~s} \mathrm{a}$ $94{ }^{\circ} \mathrm{C}$; seguido de 35 ciclos de $30 \mathrm{~s}$ a $94{ }^{\circ} \mathrm{C}, 60 \mathrm{~s}$ a $60{ }^{\circ} \mathrm{C}$ e $30 \mathrm{~s}$ a $68{ }^{\circ} \mathrm{C}$; com uma etapa final de 10 min a $68{ }^{\circ} \mathrm{C}$. Os fragmentos resultantes foram analisados por eletroforese em gel de agarose $1 \%$ conforme descrito na Seção 1.3 deste capítulo.

Tabela 1 - Primers utilizados para clonagem no vetor modificado pRSETaTF.

\begin{tabular}{clc}
\hline Primer & \multicolumn{1}{c}{ Sequência } & Sítio \\
\hline FOLR1(pPICZ $\alpha$ A)F & 5'AGATCTATGCAGACAAGGATTGCATGGGCCAGG & BglII \\
& ACTGAGC & \\
FOLR1 $(\mathrm{pPICZ} \alpha A) \mathrm{S}$ & 5'GAATTCTCAGCTGAGCAGCCACAGCAGCATTAG & EcoRI \\
& GGCC & \\
\hline
\end{tabular}

\subsubsection{Subclonagem em vetor modificado pRSETaTF-FOLRI(Life technologies)}

O produto de PCR do gene FOLR1 foi extraído e purificado do gel de agarose. O inserto foi, então, submetido à reação de digestão com as endonucleases de restrição EcoRI (Fermentas) e BglII (Fermentas), obtendo-se um inserto compatível para a subclonagem no vetor modificado pRSETaTF (Life Technologies). A modificação deste vetor pRSET foi 
promovida pela adição da proteína Trigger factor de E. coli que, nesta construção e em frame de leitura auxilia na solubilidade e na capacidade de enovelamento da proteína clonada subsequente, no caso FR $\alpha$. Para proporcionar a clonagem do receptor, o vetor foi inicialmente tratado com SacI (Fermentas) e, então, passou por um tratamento com T4 DNA Polimerase (Fermentas) para obtenção de uma extremidade 3' cega (blunt). Em seguida, a outra extremidade coesiva foi produzida através da utilização da endonuclease de restrição BamHI, sendo esta compatível com a clonagem na extremidade $B g l I I$ do inserto. Uma vez tratados e purificados, vetor e inserto (1:3, respectivamente) foram submetidos à reação de ligação com a enzima T4 DNA Ligase (Promega), mantida por $1 \mathrm{~h} \mathrm{a} 4^{\circ} \mathrm{C}$. O esquema da reação de ligação um mapa do vetor modificado estão demonstrados nas Figuras 6 e 7. Em seguida, todo o conteúdo da reação de ligação foi introduzido nas células de E. coli DH10ß competentes pelo método de transformação por choque térmico, descrito a seguir (Seção 1.6).

Figura 5 - Representação esquemática da etapa de clonagem do FOLR1 no veto r modificado pRSETaTF.
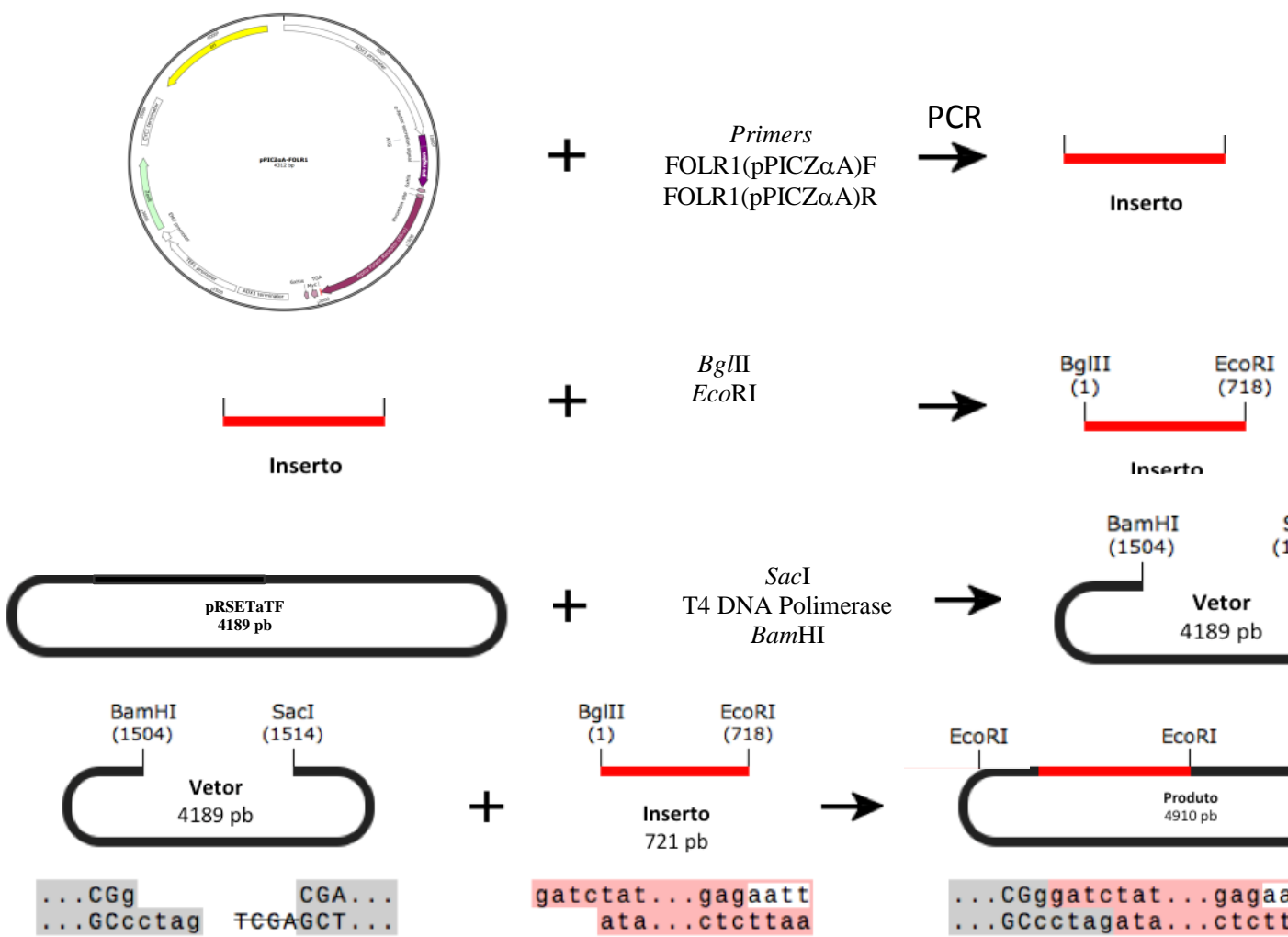

Fonte: Autoria própria com auxílio do software SnapGene.
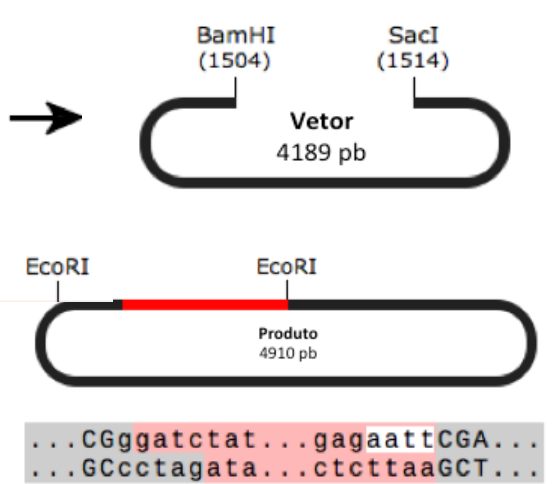
Figura 6 - Predição do mapa e sequência do vetor modificado pRSETaTF clonado com o fragmento FOLR1 entre os sítios de restrição das endonucleases BamHI e SacI. Essa construção codifica a expressão da proteína rFR $\alpha$ em fusão com a proteína Trigger Factor (E. coli) na porção N-terminal da proteína, além de uma $6 \times$ His-tag. Software SnapGene.
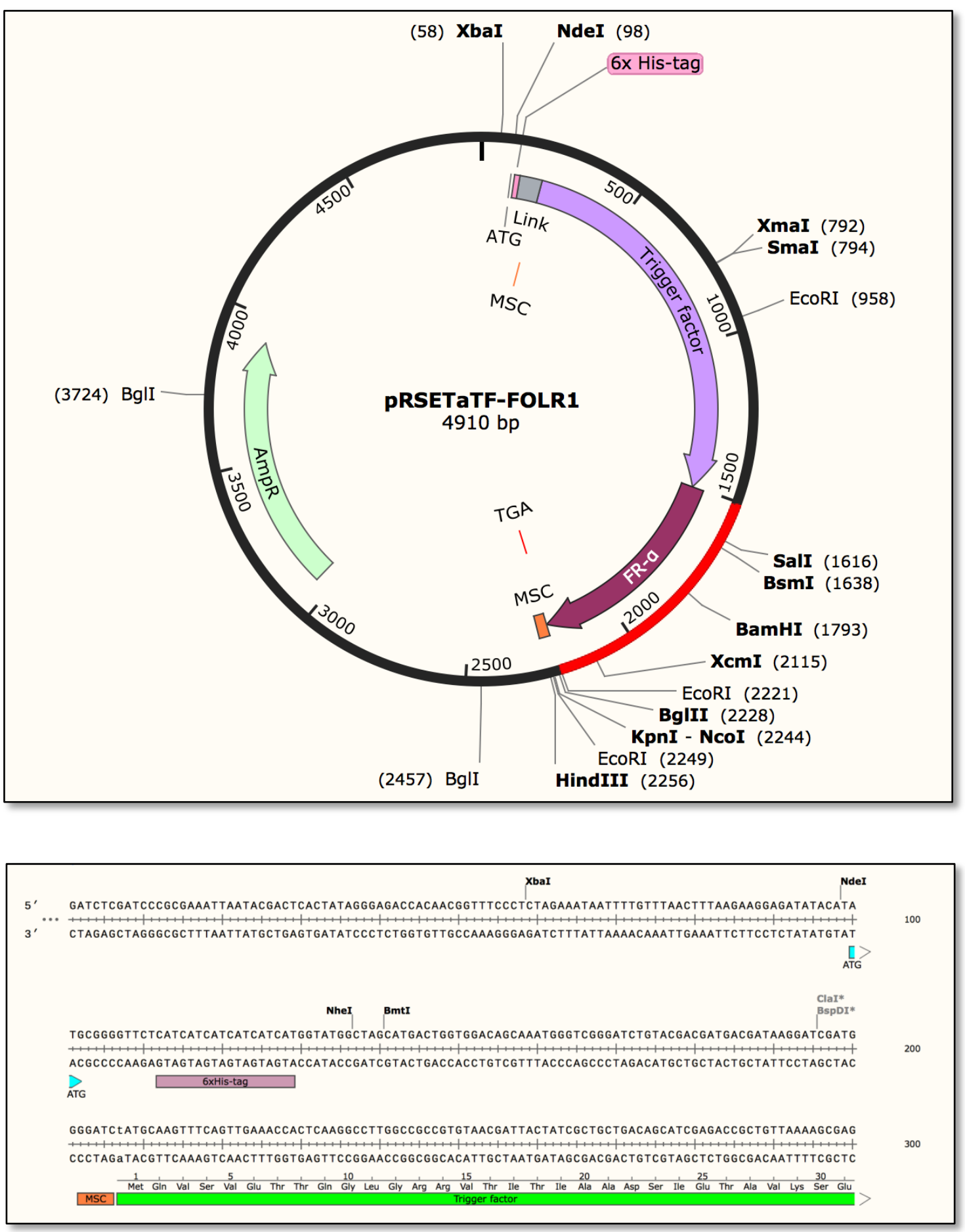


\section{SnaBI}

CTGGTCAACGTTGCGAAAAAAGTACGTATTGACGGCTTCCGCAAAGGCAAAGTGCCAATGAATATCGTTGCTCAGCGTTATGGCGCGTCTGTACGCCAGG GACCAGTTGCAACGCTTTTTTCATGCATAACTGCCGAAgGCGTTTCCGTTTCACGGTTACTTATAGCAACGAGTCGCAATACCGCGCAGACATGCGgTCC

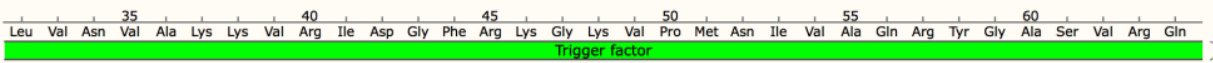

\section{BsterI}

ACGTTCTGgGtGACCTGATGAGCCGTAACTTCATTGACGCCATCATTAAAGAAAAAATCAATCCGGCTGGCGCACCGACTTATGTTCCGgGCGAATACAA

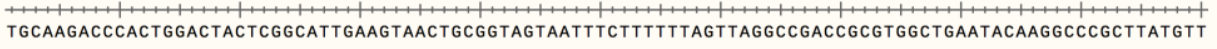

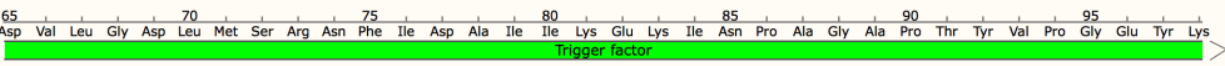
GCTGGGTGAAGACTTCACTTACTCTGTAGAGTTTGAAGTTTATCCGGAAGTTGAACTGCAGGGTCTGGAAGCGATCGAAGTTGAAAAACCGATCGTTGAA CGACCCACTTCTGAAGTGAATGAGACATCTCAAACTTCAAATAGGCCTTCAACTTGACGTCCCAGACCTTCGCTAGCTTCAACTTTTGGCTAGCAACTT 100
Leu Gly Glu Asp Phe Thr Tyr Ser Val Glu Phe Glu val Tyr Pro Glu Val Glu Leu Gin Gly Leu Glu Ala ile Glu Val Glu Lys Pro ile Val Giu SphI

GTGACCGACGCTGACGTTGACGgCATGCTGGATACTCTGCGTAAACAGCAGGCGACCTGGAAAGAAAAAGACGGCGCTGTTGAAGCAGAAGACCGCGTAA CACTGGCTGCGACTGCAACTGCCGTACGACCTATGAGACGCATTTGTCGTCCGCTGGACCTTTCTTTTTCTGCCGCGACAACTTCGTCTTCTGGCGCATT

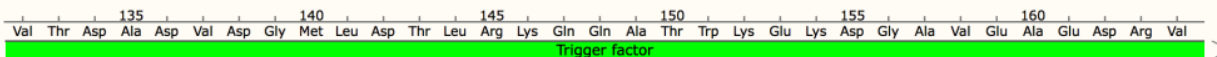

CCATCGACTTCACCGGTTCTGTAGACGGCGAAGAGTTCGAAGGCGGTAAAGCGTCTGATTTCGTACTGGCGATGGGCCAGGGTCGTATGATCCCGGGCTT GGTAGCTGAAGTGGCCAAGACATCTGCCGCTTCTCAAGCTTCCGCCATTTCGCAGACTAAAGCATGACCGCTACCCGGTCCCAGCATACTAGgGCCCGAA

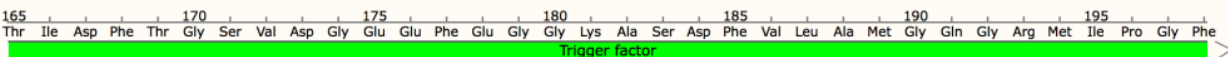

TGAAGACGGTATCAAAGGCCACAAAGCTGGCGAAGAGTTCACCATCGACGTGACCTTCCCGGAAGAATACCACGCAGAAAACCTGAAAGGTAAAGCAGCG ACTTCTGCCATAGTTTCCGGTGTTTCGACCGCTTCTCAAGTGGTAGCTGCACTGGAAGGGCCTTCTTATGGTGCGTCTTTGGACTTTCCATTTCGTCGC \begin{tabular}{l}
200 \\
\hline Glu Asp Gly Ile Lys Gly His Lys Ala Gly Glu Glu Phe Thr fle Asp Val Thr Phe Pro Glu Glu Tyr His Ala Glu Asn Leu Lys Gly Lys Ala Ala
\end{tabular}

AAATTCGCTATCAACCTGAAGAAAGTTGAAGAGCGTGAACTGCCGGAACTGACTGCAGAATTCATCAAACGTTTCGGCGTTGAAGATGGTTCCGTAGAAG TTTAAGCGATAGTTGGACTTCTTTCAACTTCTCGCACTTGACGGCCTTGACTGACGTCTTAAGTAGTTTGCAAAGCCGCAACTTCTACCAAGGCATCTTC

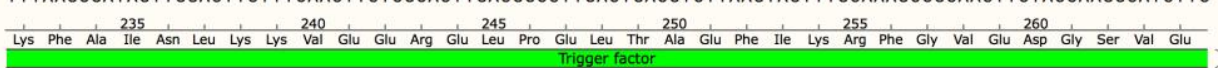

BssHII

GTCTGCGCGCTGAAGTGCGTAAAAACATGGAGCGCGAGCTGAAGAGCGCCATCCGTAACCGCGTTAAGTCTCAGGCGATCGAAGGTCTGGTAAAAGCTAA

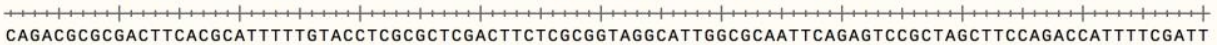

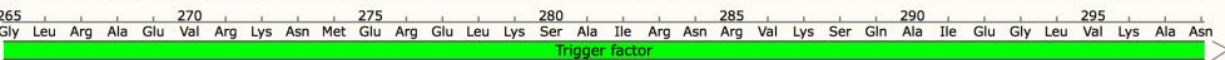

BsgI

CGACATCGACGTACCGGCTGCGCTGATCGACAGCGAAATCGACGTTCTGCGTCGCCAGGCTGCACAGCGTTTCGGTGGCAACGAAAAACAAGCTCTGGAA GCTGTAGCTGCATGGCCGACGCGACTAGCTGTCGCTTTAGCTGCAAGACGCAGCGGTCCGACGTGTCGCAAAGCCACCGTTGCTTTTTGTTCGAGACCTT

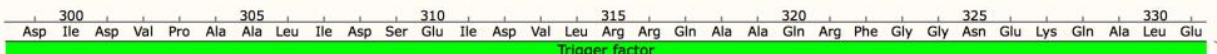

CTGCCGCGCGAACTGTTCGAAGAACAGGCTAAACGCCGCGTAGTTGTTGGCCTGCTGCTGGGCGAAGTTATCCGCACCAACGAGCTGAAAGCTGACGAAG GACGGCGGCTTGACAAGCTTCTTGTCCGATTTGCGgCGCATCAACAACCGGACGACGACCCGCTTCAATAGgCGTGGTTGCTCGACTTTCGACTGCTTC

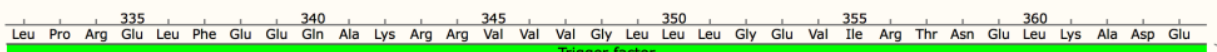

Bsiw

AGCGCGTGAAAGGCTGATCGAAGAGATGGCTTCTGCGTACGAAGATCCGAAAGAAGTTATCGAGTTCTACAGCAAAAACAAAGAACTGATGGACAACAT TCGCGCACTTTCCGGACTAGCTTCTCTACCGAGGACGCATGCTTCTAGGCTITCTTCAATAGCTCAAGATGTCGTTTTTGTTTCTTGACTACCTGTTGTA

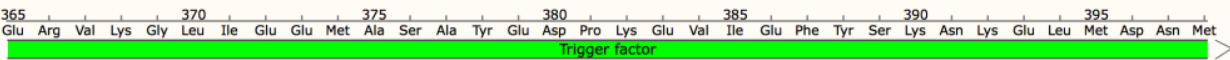

GCGCAATGTTGCTCTGGAAGAACAGGCTGTTGAAGCTGTACTGGCGAAAGCGAAAGTGACTGAAAAAGAAACCACTTTCAACGAGCTGATGAACCAGCAG

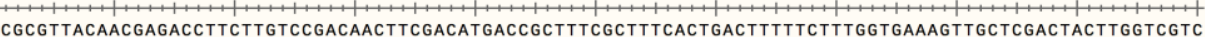

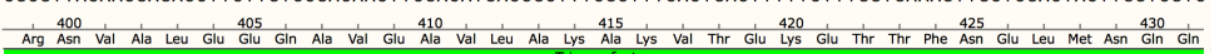
Arg Asn Val Ala Leu Glu Glu Gin Ala Val Glu Ala Val Leu Ala Lys Ala Lys Val Thr Glu Lys Glu Thr Thr Phe Asn Glu Leu Met Asn Gln Gin 


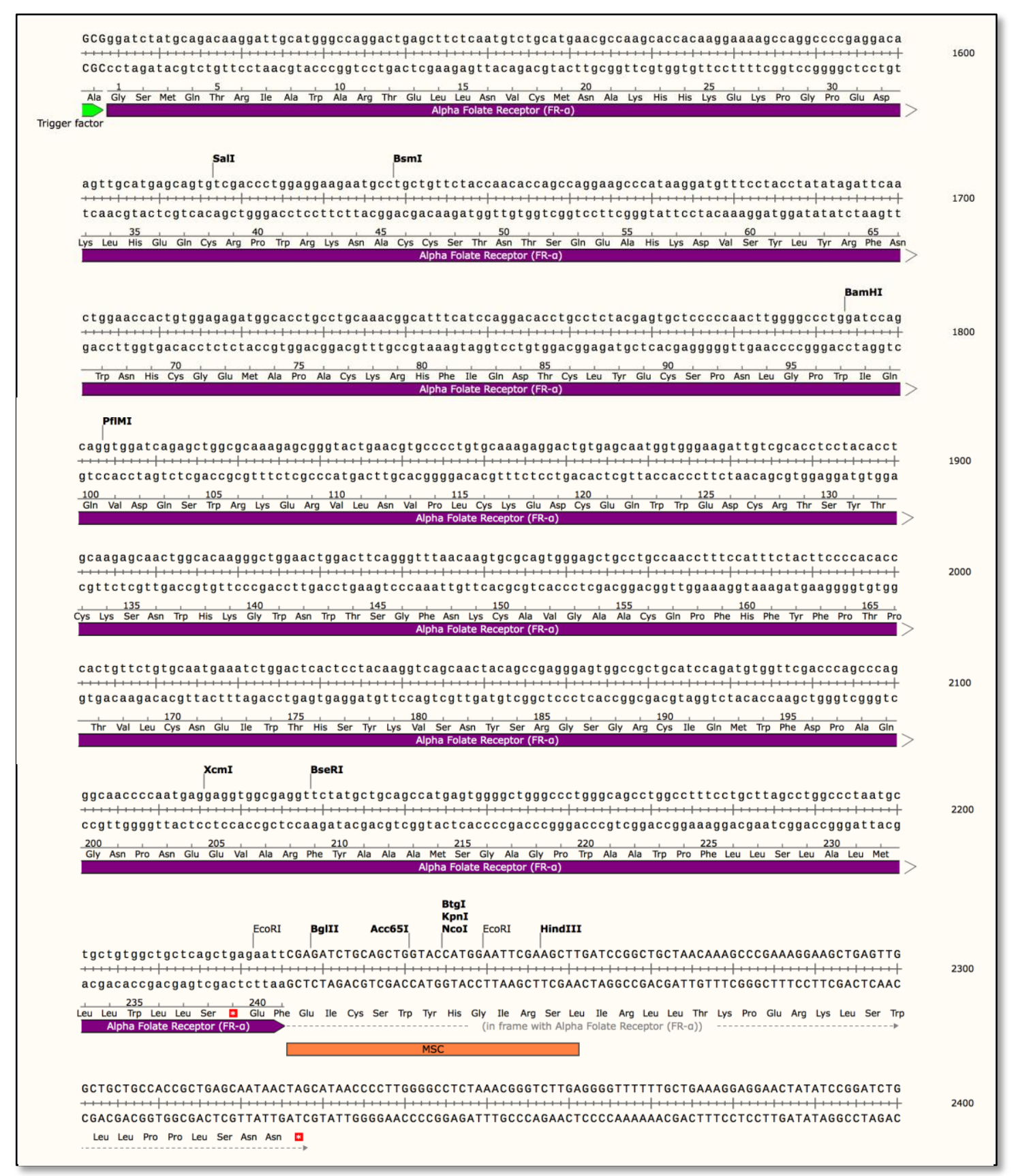

Fonte: Autoria própria com auxílio do software SnapGene. 


\subsection{Preparação de células $E$. coli competentes}

Células de E.coli foram cultivadas em $10 \mathrm{~mL}$ de meio $\mathrm{LB}$ e incubadas a $37^{\circ} \mathrm{C}$ overnight de modo estático, o que possibilitou que atingissem uma D.O.600nm entre 0,4 e 0,6, ideal para o preparo de células competentes. As células foram coletadas por centrifugação a $2057 \times$ g por $10 \mathrm{~min}$ a $4{ }^{\circ} \mathrm{C}$ e ressuspendidas em $3 \mathrm{~mL}$ de solução $100 \mathrm{mmol} \mathrm{L}^{-1} \mathrm{CaCl}_{2}$ estéril e gelada. Em seguida, as células foram submetidas à nova centrifugação, desta vez a $1575 \times \mathrm{g}$ por 5 min a $4{ }^{\circ} \mathrm{C}$ e ressuspendidas em $600 \mu \mathrm{L}$ da solução de $\mathrm{CaCl}_{2}$. Por fim, alíquotas foram depositadas em tubos de microcentrífuga e utilizadas para transformação, ou congeladas em nitrogênio líquido e armazenadas a $-80{ }^{\circ} \mathrm{C}$.

\subsection{Transformação por choque térmico}

Células de E. coli $(50 \mu \mathrm{L})$ previamente tratadas com solução gelada de $100 \mathrm{mmol} \mathrm{L}^{-1}$ $\mathrm{CaCl}_{2}$ foram adicionadas à reação de ligação ou aos clones, e mantidas a $4{ }^{\circ} \mathrm{C}$ por $30 \mathrm{~min}$. Em seguida foram submetidas ao choque térmico por incubação em banho-maria a $42{ }^{\circ} \mathrm{C}$ por $30 \mathrm{~s}$ e resfriadas em gelo por 2 min. Posteriormente, adicionou-se $200 \mu \mathrm{L}$ de meio LB e as células foram cultivadas a $37^{\circ} \mathrm{C}$ por $1 \mathrm{~h}$ sob agitação $(250 \mathrm{rpm})$ ou overnight estático. Após o cultivo, as células transformadas foram inoculadas em meio seletivo LB-ágar.

A confirmação das células recombinantes foi baseada no crescimento de colônias no meio seletivo e por análise de restrição, PCR e sequenciamento do DNA plasmidial dos clones resistentes. Alíquotas dos plasmídeos transformantes foram estocadas a $-20{ }^{\circ} \mathrm{C}$.

\subsection{Expressão da proteína $\mathrm{rFR} \alpha \mathrm{em} E$. coli}

Culturas recombinantes de cepas de expressão de E. coli foram cultivadas overnight em pré-inóculo contendo $5 \mathrm{~mL}$ do meio LB seletivo a $37{ }^{\circ} \mathrm{C}$ e $250 \mathrm{rpm}$. Posteriormente, os 5 $\mathrm{mL}$ do pré-inóculo foram adicionados a um inóculo de $200 \mathrm{~mL}$ de meio LB suplementado com antibiótico(s) e mantido sob agitação a $250 \mathrm{rpm}$ a $37{ }^{\circ} \mathrm{C}$, até que a cultura atingisse a fase $\log$ de crescimento, identificada por D.O.600nm 0,4-0,6. Nessa etapa, uma alíquota de 1,0 mL foi centrifugada e ressuspendida em tampão de amostra (Tris-HCL 125 mmol L-1; pH 6,8; 4\% 
$(\mathrm{m} / \mathrm{v})$ SDS; $20 \%(\mathrm{v} / \mathrm{v})$ glicerol; $0,2 \%(\mathrm{~m} / \mathrm{v})$ de azul de bromofenol e $0,1 \mathrm{~mol} \mathrm{~L}^{-1} \beta$ Mercaptoetanol) para posterior análise em eletroforese de gel de poliacrilamida. A indução da expressão da proteína $\mathrm{rFR} \alpha$ foi promovida através da adição de $0,4 \mathrm{mmol} \mathrm{\textrm {L } ^ { - 1 }}$ de IPTG (isopropil-beta-D-tiogalactopiranosideo). Em determinados experimentos a cultura foi mantida sob agitação em diferentes condições: $37{ }^{\circ} \mathrm{C}$ por $5 \mathrm{~h}, 30{ }^{\circ} \mathrm{C}$ por $5 \mathrm{~h}$ e $20{ }^{\circ} \mathrm{C}$ por $20 \mathrm{~h}$. Em seguida, todo o conteúdo foi centrifugado a $3500 \times$ g por 20 min a $4{ }^{\circ} \mathrm{C}$. A análise e a confirmação da expressão foram promovidas através de eletroforese em condições desnaturantes (SDS-PAGE), conforme descrito na Seção 1.4.1, Capítulo 1.

\subsection{Ensaio de solubilidade da proteína recombinante.}

Uma vez confirmada a expressão do receptor, foi verificada a sua solubilidade dando continuação aos experimentos de expressão. Há de ressaltar que a metodologia aqui descrita foi a que se mostrou mais eficaz, uma vez que outras metodologias de lise e purificação testadas não se mostraram adequadas.

As células foram centrifugadas a $3000 \times$ g por 20 min a $4{ }^{\circ} \mathrm{C}$, e o precipitado celular ressuspendido em tampão fosfato-salino, PBS 1×, pH 7,2, suplementado com $500 \mathrm{mmol} \mathrm{L}^{-1}$ de $\mathrm{NaCl}$ e $20 \mathrm{mg} \mathrm{mL}^{-1}$ de lisozima. Após o congelamento overnight as células foram submetidas à lise física com o auxílio de uma seringa, até que uma solução homogênea fosse obtida (aproximadamente 8 repetições). Após a ruptura celular as frações solúvel e insolúvel foram separadas por centrifugação a $3000 \times$ g por $10 \mathrm{~min}$, à $4{ }^{\circ} \mathrm{C}$. Amostras de cada uma dessas frações foram tratadas com tampão o da amostra para posterior análise em gel de poliacrilamida, Seção 1.4.1, Capítulo 1.

Durante o andamento do trabalho, em determinados experimentos, a proteína rFR $\alpha$ se mostrou insolúvel, sendo necessário a execução de testes de refolding da proteína insolúvel. Nestes testes foram utilizado agentes caotrópicos: $8 \mathrm{~mol} \mathrm{~L}^{-1}$ de uréia, $6 \mathrm{~mol} \mathrm{~L}^{-1}$ de guanidina e adição de 2-metil-2,4-pentanediol (MPD) na presença de SDS. (34) 


\subsubsection{Purificação da proteína recombinante}

Após comprovada a solubilidade do receptor recombinante, os experimentos de purificação foram iniciados. A fração solúvel contendo a enzima após rompimento foi filtrada em filtro de 0,45 $\mu \mathrm{m}$ e adicionada à resina de níquel (Ni-NTA Agarose, Qiagen) previamente equilibrada com $1 \times$, (phosphate buffered saline; $\mathrm{pH} 7,2 ; 137 \mathrm{mmol} \mathrm{L}^{-1} \mathrm{NaCl} ; 2,7 \mathrm{mmol} \mathrm{L}^{-1}$ $\mathrm{KCl} ; 10$ mmol L ${ }^{-1} \mathrm{Na}_{2} \mathrm{HPO}_{4} ; 2$ mmol L ${ }^{-1} \mathrm{KH}_{2} \mathrm{PO}_{4}$ ) suplementado com 500 mmol L${ }^{-1}$ de $\mathrm{NaCl}$. Após 3 lavagens com $10 \mathrm{~mL}$ de tampão de lavagem (PBS 1×, $500 \mathrm{mmol} \mathrm{L}^{-1} \mathrm{NaCl} ; 5 \mathrm{mmol} \mathrm{L}{ }^{-1}$ de imidazol) a enzima ligada à resina foi eluída com $250 \mathrm{mmol} \mathrm{L}^{-1}$ ou gradiente $(10,50,100$, 150, 200 e $250 \mathrm{mmol} \mathrm{L}^{-1}$ ) de imidazol. As frações eluídas foram analisadas em gel de poliacrilamida (Seção 1.4.1, Capítulo 1).

\subsection{Técnicas para análise e confirmação de clonagem}

\subsubsection{Análise das colônias transformantes por PCR}

A análise das colônias transformantes por PCR, a partir do DNA genômico extraído, foi realizada com o primer forward (FOLR1 $(\mathrm{pPICZ} \alpha \mathrm{A}) \mathrm{F})$ descrito na Tabela 1 e o primer reverse M13. Aproximadamente $1 \mu \mathrm{g}$ de DNA genômico foi adicionado à reação-padrão, seguindo programa descrito no item 1.5.2.1. Para a confirmação da amplificação do fragmento de interesse todo o conteúdo das reações foi analisado por eletroforese em gel de agarose $1 \%$ (Seção 1.3, Capítulo 2).

\subsubsection{Análise de restrição enzimática}

Os rDNAs (DNAs recombinantes) obtidos através de clonagem molecular foram submetidos à restrição com enzimas específicas e analisados conforme descrito na Seção 1.3, Capítulo 2. Amostras que continham as bandas características que compreendessem o perfil de digestão esperado, de acordo com sua posição de migração, foram consideradas clones positivos. A ausência de banda na posição de migração esperada indicou a ausência do inserto no vetor, ou seja, ineficiência da clonagem. 


\subsubsection{Análise por sequenciamento}

As análises de sequenciamento foram promovidas no Instituto de Física de São Carlos, no equipamento 3130 Genetic Analyzer (Applied Biosystem) com os primers descritos na Tabela 1, utilizados também na etapa de PCR (Seção 1.5.2.1, Capítulo 2).

\subsection{Técnicas analíticas para análise e detecção de proteínas}

A necessidade de execução de cada um dos métodos descritos a seguir foi previamente avaliada em função do andamento dos experimentos.

\subsubsection{Separação de proteínas por eletroforese SDS-PAGE}

O acompanhamento das expressões e purificações dos extratos proteicos foi promovido através de análise por SDS-PAGE utilizando-se gel de poliacrilamida 10 ou $15 \%$ ao qual foi aplicada uma voltagem fixa de $90 \mathrm{~V}$. Às amostras foi adicionado tampão de amostra $5 \times\left(0,1 \%(\mathrm{~m} / \mathrm{v})\right.$ azul de bromofenol; $10 \%(\mathrm{v} / \mathrm{v})$ glicerol; $100 \mathrm{mmol} \mathrm{L}^{-1} \beta$ mercaptoetanol; $2 \%(\mathrm{~m} / \mathrm{v}) \mathrm{SDS} ; 50 \mathrm{mmol} \mathrm{L}^{-1}$ Tris-HCl; $\mathrm{pH} \mathrm{6,8).} \mathrm{O} \mathrm{gel} \mathrm{foi} \mathrm{corado} \mathrm{com}$ Comassie Brilliant Blue R-250 e fotodocumentado.

\subsubsection{Análise por Western Blot}

Após a separação das amostras por SDS-PAGE, de acordo com o procedimento descrito no item 2.9.1, o gel foi submetido à etapa de transferência das proteínas para uma membrana de nitrocelulose (NC) por 90 min a $80 \mathrm{~V}$, com o Kit Mini Trans-Blot ${ }^{\circledR}$ Cell, BioRad, em tampão de transferência (39 mmol L ${ }^{-1}$ glicina; $48 \mathrm{mmol} \mathrm{L}^{-1}$ Tris; 0,0375\% (m/v) SDS e 20\% (v/v) metanol). A seguir, foi promovida uma etapa de bloqueio com leite Molico em pó desnatado 4\% (m/v; em PBS-T: $0,05 \mathrm{mmol} \mathrm{L}^{-1}$ Tween-20, PBS $\left.1 \times\right)$ por $1 \mathrm{~h}$ à temperatura ambiente, ou overnight a $4{ }^{\circ} \mathrm{C}$. Após a lavagem da membrana, a presença da proteína em fusão com a 6xHis-tag foi analisada utilizando-se o anticorpo Ni-NTA AP conjugate (Qiagen) (diluído 1:10000 em PBS-T) para as detecções diretas com a pastilha SigmaFAST ${ }^{\mathrm{TM}}$ 
BCIP®/NBT B5655 (Sigma) e Ms mAb 6×His-tag (1:5000 em PBS-T 1\%) seguido da lavagem e incubação secundária com peroxi labeled goat anti-mouse IgG (1:2000 em 1\% leite PBS-T) para detecções secundárias através da horseradish peroxidase (HRP), Kit SuperSignal West Pico Chemiluminescent Substrate, Thermo Scientific. Neste último caso, a membrana foi exposta ao filme fotográfico e revelada em tampões KODAK como recomendado pelo fabricante. Em ambos os casos, após a etapa de revelação tanto a membrana quanto o filme foram fotodocumentados.

\subsubsection{Análises no OFFGEL}

As análises foram promovidas no equipamento Agilent 2100 OFFGEL Fractionator (Agilent Technologies) conforme protocolo do fabricante, sendo a amostra distribuída nos reservatórios sobre a fita de $13 \mathrm{~cm}$ linear, com gradiente de $\mathrm{pH}$ imobilizado na faixa de $\mathrm{pH} 3$ 10 (GE Healthcare) e submetida à focalização isoelétrica por 48 h. Em seguida, as amostras resultantes foram analisadas por SDS-PAGE (conforme Seção 1.4.1, Capítulo 1) sendo os géis corados com nitrato de prata.

\subsubsection{Análise de peptídeos por LC-MS/MS}

\subsubsection{Digestão de proteínas em gel}

As bandas referentes à proteína estudada foram excisadas do gel manualmente e transferidas para microtubos individuais. O SDS e o corante presentes nas amostras foram eliminados com $500 \mu \mathrm{L}$ de solução Destain (acetonitrila, ACN: tampão bicarbonato de amônio aquoso $100 \mathrm{mmol} \mathrm{L}{ }^{-1}$, AmBic; 1:1) overnight a $37{ }^{\circ} \mathrm{C}$, sob agitação. Em seguida, a solução Destain foi removida, seguida pela desidratação dos géis com $200 \mu \mathrm{L}$ de ACN (100\%) por 5 min. A etapa de desidratação foi repetida e a solução restante foi evaporada em speed vacuum. As proteínas foram reduzidas com $30 \mu \mathrm{L}$ de ditiotreitol (DTT) $10 \mathrm{mmol} \mathrm{L}^{-1}$ por 30 min a $56{ }^{\circ} \mathrm{C}$, e a solução resultante foi removida. A alquilação se deu pela adição de uma solução de iodoacetamida (IAA $50 \mathrm{mmol} \mathrm{L}^{-1} \mathrm{em} \mathrm{AmBic} 100 \mathrm{mmol} \mathrm{L}{ }^{-1}$ ) por $30 \mathrm{~min}$, fora do alcance da luz, a temperatura ambiente. Após a solução resultante ser removida, as 
amostras foram lavadas com $100 \mu \mathrm{L}$ de AmBic por 10 min, seguido por uma desidratação com $200 \mu \mathrm{L}$ de ACN $100 \%$ por 5 min. A reidratação foi promovida com $200 \mu \mathrm{L}$ de solução AmBic $100 \mathrm{mmol} \mathrm{L}^{-1}$ por $10 \mathrm{~min}$. Os géis excisados foram, então, desidratados com ACN,

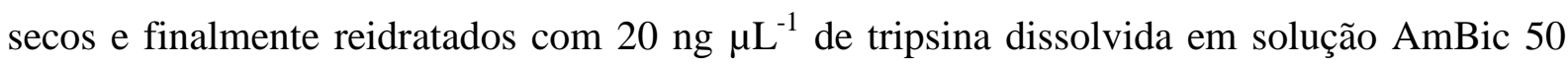
mmol L. Após $30 \mathrm{~min}$ em banho de gelo, os tubos com as amostras e a tripsina foram incubados a $37{ }^{\circ} \mathrm{C}$ overnight. No dia seguinte, os sobrenadantes foram transferidos para outros tubos e adicionou-se solução de ácido fórmico para concentração final de $0,1 \%$. (35) As soluções de peptídeos foram secas em speed vac e os tubos armazenados a $-80{ }^{\circ} \mathrm{C}$ para posterior análise de MS.

A existência de sais e outros contaminantes na amostra limitam a eficiência de ionização, contribuindo para o ruído no espectro de massas. Para retirada destes contaminantes, foi promovida uma etapa cromatográfica de limpeza das amostras, utilizandose micro-colunas C-18 (TopTip, Glygen, Columbia, MD), de acordo com protocolo do fabricante.

\subsubsection{Análise dos Peptídeos por LC-MS/MS}

Os peptídeos digeridos foram analisados por cromatografia líquida acoplada à espectromeria de massas. Para isso, foi empregado o sistema EASY-nLC (Thermo Scientific) acoplado a um espectrômetro de massas híbrido ion trap linear-Orbitrap (LTQ Orbitrap Velos, Thermo Scientific) com fonte de íons nanospray Nano-Flex II nanospray (Thermo Scientific).

Para a separação dos peptídeos por cromatografia líquida empregou-se uma coluna capilar C18 (10 cm $\times 75 \mu \mathrm{m}$ DI, Thermo Scientific), utilizando-se como fases móveis 0,1\% (v/v) de ácido fórmico em água (A) e 0,1\% (v/v) de ácido fórmico em ACN (B).

A coluna foi equilibrada com $95 \%$ de fase móvel A, e as amostras foram injetadas (10 $\left.\mu \mathrm{L} \mathrm{min} \min ^{-1}, 4 \mathrm{~min}\right)$ e eluídas sob vazão de $300 \mathrm{~nL} \min ^{-1}$ através do seguinte gradiente de eluição: isocrático a 5\% B, 5 min; 5-30\% B, 15 min; 30-80\% B durante 10 min e isocrático $80 \%$ de B por 5 min. O eluato foi inserido no espectrômetro de massas através de uma fonte de íons nanospray. Os dados de LC-MS/MS foram adquiridos utilizando o software XCalibur, 
versão 2.0.7 (Thermo Fisher Scientific). Os parâmetros utilizados para as análises foram: modo scan no intervalo de $400-1800 \mathrm{~m} / \mathrm{z}$, modo positivo, tensão do capilar de $2500 \mathrm{~V}$, nebulizador a 8,0 psi, gás secante a uma vazão de 5,0 $\mathrm{L} \mathrm{min}^{-1}$ e temperatura para evaporação do spray de $200{ }^{\circ} \mathrm{C}$. Uma janela de exclusão de 45 s foi utilizada para eliminar redundância de sequenciamento de peptídeos abundantes.

\subsubsection{Análise dos Dados}

Os dados obtidos foram processados utilizando-se o software Proteome Discoverer 1.2.0 (Thermo Scientific), analisados e comparados através do programa SEQUEST.(36) Foram utilizados os seguintes parâmetros para a busca: fragmentação por CID (dissociação induzida por colisão), tolerância de $10 \mathrm{ppm}$ dos íons precursores e, para fragmentos de massa, de 2,5 Da e 0,8 Da para espectros de baixa e alta resolução, respectivamente, banco de dados Uniprot-Human (Feb 25, 2012 version, 81,213 protein sequences), digestão com tripsina, duas clivagens perdidas permitidas e, por fim, duas modificações, sendo uma fixa (carbamidometilação de cisteínas) e a outra variável (oxidação de metionina). Nos casos em que esta análise não conseguiu gerar resultados significativos conforme o esperado, utilizou-se a plataforma on line PeptideCutter (ExPASy) para a comparação direta entre os peptídeos obtidos no presente experimento com aqueles obtidos através de digestão virtual da proteína com tripsina.

\subsection{Ensaio de atividade, produção de lipossomos e análises microscópicas}

Os experimentos subsequentes foram promovidos com a proteína recombinante TFFR $\alpha$ e com extrato proteico enriquecido em proteínas GPI ancoradas de células HeLa, de tumor cervical, rico em receptores, o que inclui o FR $\alpha$. Desta forma, foi utilizada como padrão positivo para ensaios de afinidade comparativos com a TFFR $\alpha$. 


\subsubsection{Ensaio de atividade em microbalança eletroquímica}

Com o intuito de observar a atividade da proteína recombinante foram promovidos testes com Microbalança Eletroquímica de Cristal de Quartzo (MECQ), utilizando a RQCM/Maxtek acoplada a um potenciostato/galvanostato Autolab (modelo PGSTAT302 da Metrohm Autolab B.V.) interfaceados pelos programas RQCM e GPES 4.9, respectivamente. O eletrodo de trabalho utilizado no estudo consistiu em um cristal de quartzo, com corte AT, frequência fundamental de ressonância de $5 \mathrm{MHz}$ e sensibilidade calculada de 0,056 \pm 0,018 $\mathrm{Hz} / \mathrm{ng} \mathrm{cm}^{-2}$.

O experimento foi promovido com as proteínas GPI ancoradas extraídas de células HeLa, e paralelamente com a proteína recombinante TFFR $\alpha$ para que a atividade de ambas pudessem ser avaliadas e comparadas, servindo a primeira como um controle positivo. As proteínas foram incubadas em eletrodo por $24 \mathrm{~h}$, a fim de que se depositassem na superfície do mesmo. O ligante utilizado foi o tetrahidrofolato (Sigma Aldrich) diluído em PBS $1 \times \mathrm{pH}$ 7,2 .

\subsubsection{Produção de lipossomos e imobilização da proteína recombinante}

Para a produção dos lipossomos utilizou-se o protocolo descrito por Colhone et. al (2009). (30) Inicialmente, uma solução de 1,2-dipalmitoil-sn-glicero-3-fosfatidilcolina (DPPC) e colesterol (4:1 em estequiometria molar), em clorofórmio (1 mg/mL) foi dessecada a $37{ }^{\circ} \mathrm{C}$, por $1 \mathrm{~h}$. A reidratação ocorreu através da adição de $1 \mathrm{~mL}$ da solução Tris- $\mathrm{HCl} 50$ mmol L ${ }^{-1}, 2$ mmol L ${ }^{-1} \mathrm{CaCl}_{2}, 10 \mathrm{mmol} \mathrm{L}^{-1} \mathrm{NaCl}$, pH 7,25, seguida de incubação em banho seco a $60{ }^{\circ} \mathrm{C}$ (temperatura de transição do DPPC), por $1 \mathrm{~h}$ sob agitação, para a produção de vesículas multilamelares (MLV). Essa solução foi, então, submetida a sonicação por ciclos de 2 min em gelo e 2 min sob sonicação em potencia máxima até obtenção de uma solução translúcida e lipossomos de $\sim 100 \mathrm{~nm}$. Esta metodologia esta esquematizada na Figura 8 . Os lipossomos foram centrifugados em ultra-centrífuga a $100.000 \times \mathrm{g}$ por $1 \mathrm{~h}$ a $4{ }^{\circ} \mathrm{C}$, e o sobranadante (contendo pequenas vesículas unilamelares, SUV, de $\sim 100 \mathrm{~nm}$ ) foram misturados com o extrato proteico enriquecido em proteínas GPI ancoradas de células HeLa 
na quantidade de $250 \mu \mathrm{g}$ por $\mathrm{mL}$ de lipossomos. (30) Todos os lipídios utilizados foram adquiridos da AVANTI® Polar Lipids, Inc. (37)

Figura 7 - Representação esquemática da metodologia de produção dos lipossomos.

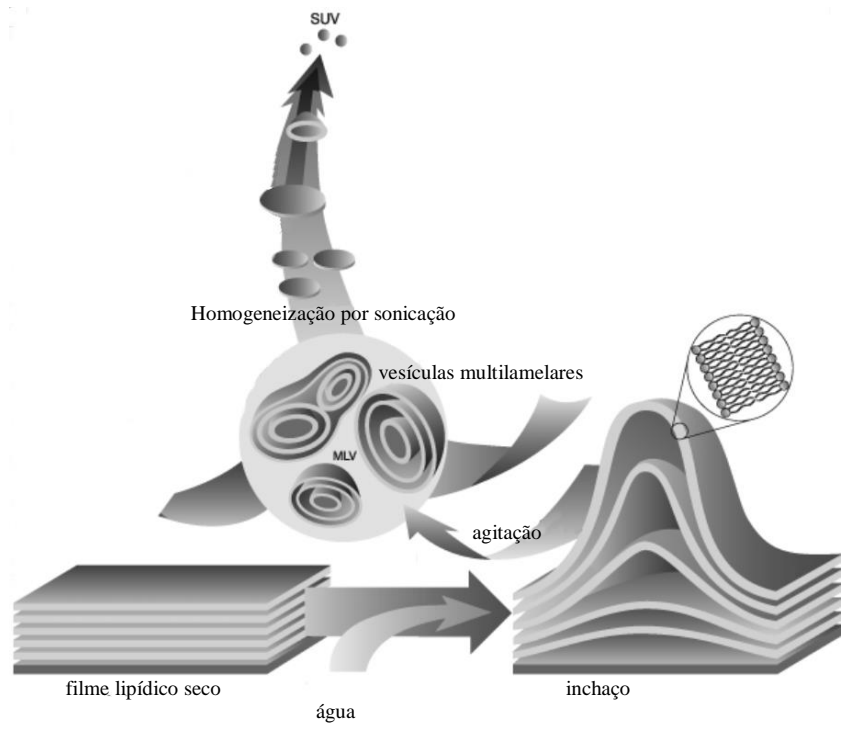

Fonte: Adaptação de Miranda (2014) a partir de LASIC, D. D. (1997 apud AVANTI® Polar Lipids, Inc., $[201-].)^{*}$

Esse mesmo procedimento foi repetido para a produção de lipossomos específicos para resíduos 6×His-tag, DGS-NTA(Ni):1,2-dioleoil-sn-glicero-3-[(ácido-N-(5amino1carboxipentil)iminodiacético)succinil] (sal de níquel), Figura 9; na proporção de DPPC/DSG-NTA/colesterol de 4/0.4/1. Outras formulações foram feitas como descrito anteriormente, substituindo-se as proteínas GPI enriquecidas por TF-FR $\alpha$ recombinante detentora de cauda His para conexão com o lipídeo possuidor de resíduos de níquel na mesma proporção de $250 \mu \mathrm{g}$ por $\mathrm{mL}$ de lipossomos. Após as incubações os lipossomos puderam ser compactados em forma de pellet por centrifugação em centrifuga eppendorf a $9.000 \times \mathrm{g}$.

* LASIC, D. D. Liposomes in Gene Delivery; CRC Press: Boca Raton, FL, 1997. 


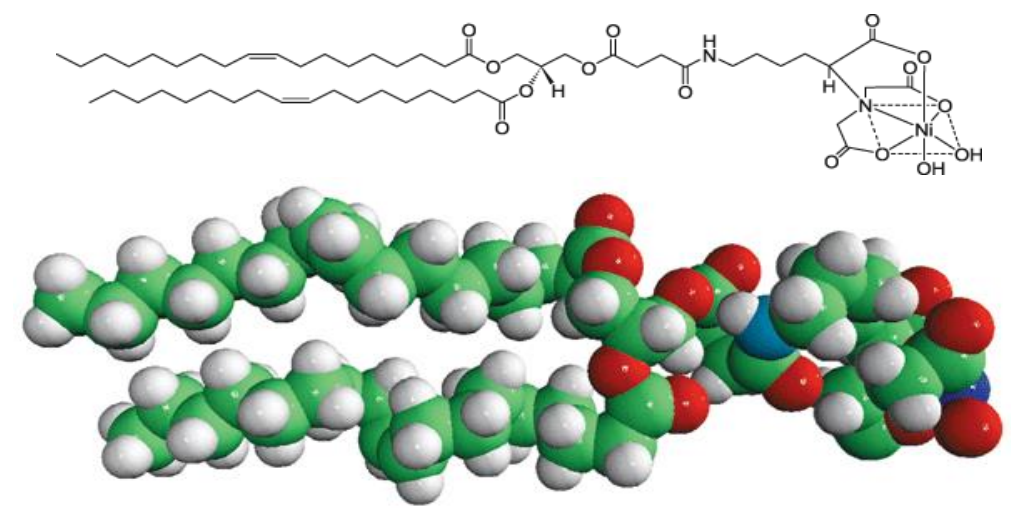

Fonte: AVANTI® Polar Lipids, Inc., [201-].

Para a confirmação da imobilização da TF-FR $\alpha$ ao lipossomo, foram promovidas análises por Western Blot , conforme descrito na Seção 1.4.3, Capítulo 1, e as bandas foram analisadas no software Quantity One, Bio-Rad.

\subsubsection{Caracterização morfológica dos proteolipossomos}

Para a análise dos proteolipossomos foi inicialmente utilizado o Microscópio Digital KH-7700 HIROX Company, LTD. As amostras foram depositadas em mica sob ação de Spinner Laurell a $1000 \mathrm{rpm}$ por 3 min, e deixadas em dessecador por $24 \mathrm{~h}$. As análises foram promovidas em magnificação $4.200 \times$.

As amostras analisadas por microscopia de força atômica (AFM) foram as mesmas preparadas para análise em microscópio óptico. Foi utilizado equipamento Nanosurf EasyScan 2 no modo de operação de não-contato com o cantilever Tap190Al-G, 45\%, $10 \mathrm{~s}$ $(50 \times 50 \mu \mathrm{m}), 400$ pontos/linha. Foi feito o tratamento linear (FIT) das imagens obtidas. 


\section{Resultados e Discussão}

\subsection{Clone pET28aFOLR1}

\subsubsection{Ensaios de expressão e solubilidade da proteína rFRa em E. coli}

Os ensaios de expressão e solubilidade foram realizados de acordo com as Seções 1.8 e 1.9, variando-se as cepas, temperatura e tempo de indução. As diferentes cepas de E. coli testadas foram: BL21(DE3) (Figura 10), BL21(DE3)pTGROE e Rosetta(DE3) (Figura 11). Contudo, a presença da proteína $\mathrm{rFR} \alpha(28,3 \mathrm{kDa})$ só foi observada quando a expressão foi realizada em cepas BL21(DE3) e, mesmo assim, de forma insolúvel. Além disso, não foi possível avaliar diferenças significativas relacionadas às condições de expressão testadas $\left(30{ }^{\circ} \mathrm{C}\right.$ por 5 h e $20{ }^{\circ} \mathrm{C}$, overnight). Cabe ressaltar que esses ensaios foram complementados com análises por Western Blot, com um anticorpo anti-His (conforme Seção 1.4.3, Capítulo 1), que confirmaram a presença da proteína recombinante na fração insolúvel do lisado celular da expressão em BL21(DE3) (Figura 10 b).

Figura 8 - Expressão rFR $\alpha$ em BL21(DE3) a $30{ }^{\circ} \mathrm{C}$ por 5 h. a) Perfil eletroforético em gel de SDS-PAGE $15 \%$ e b) Membrana de nitrocelulose Western Blot detecção direta com pastilha SigmaFAST ${ }^{\mathrm{TM}}$ BCIP®/NBT B5655 (Sigma). Canaletas: M. Padrão de tamanho molecular (Fermentas); 1. Conteúdo proteico antes da indução $\left(\mathrm{t}_{\mathrm{o}}\right) ; 2$. Conteúdo proteico após a indução; 3. Fração solúvel do lisado celular; 4. Fração insolúvel do lisado celular, respectivamente. As bandas indicadas com setas representam a $\mathrm{rFR} \alpha$, com $28,3 \mathrm{kDa}$.

a)

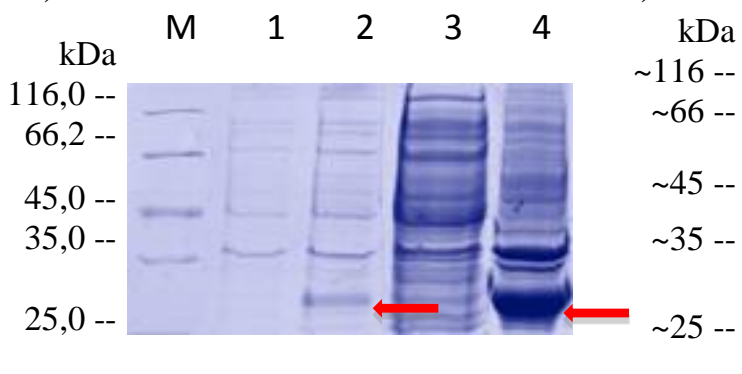

b)

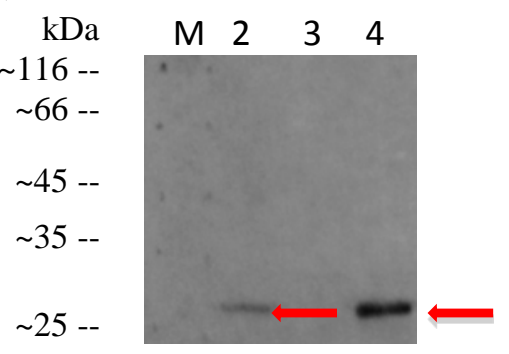

Fonte: Autoria própria. 
Figura 9 - Perfil eletroforético em gel SDS-PAGE 15\%. Expressão rFR $\alpha$ em a) BL21(DE3)pTGROE a $30{ }^{\circ} \mathrm{C}$ por 5 h e em b) BL21(DE3)Rosetta a $30{ }^{\circ} \mathrm{C}$ por 5 h. Canaletas: M. Padrão de tamanho molecular (Fermentas); 1 e 2. Conteúdo proteico antes e após a indução, respectivamente; 3 e 4 . Frações solúvel e insolúvel do lisado celular, respectivamente.

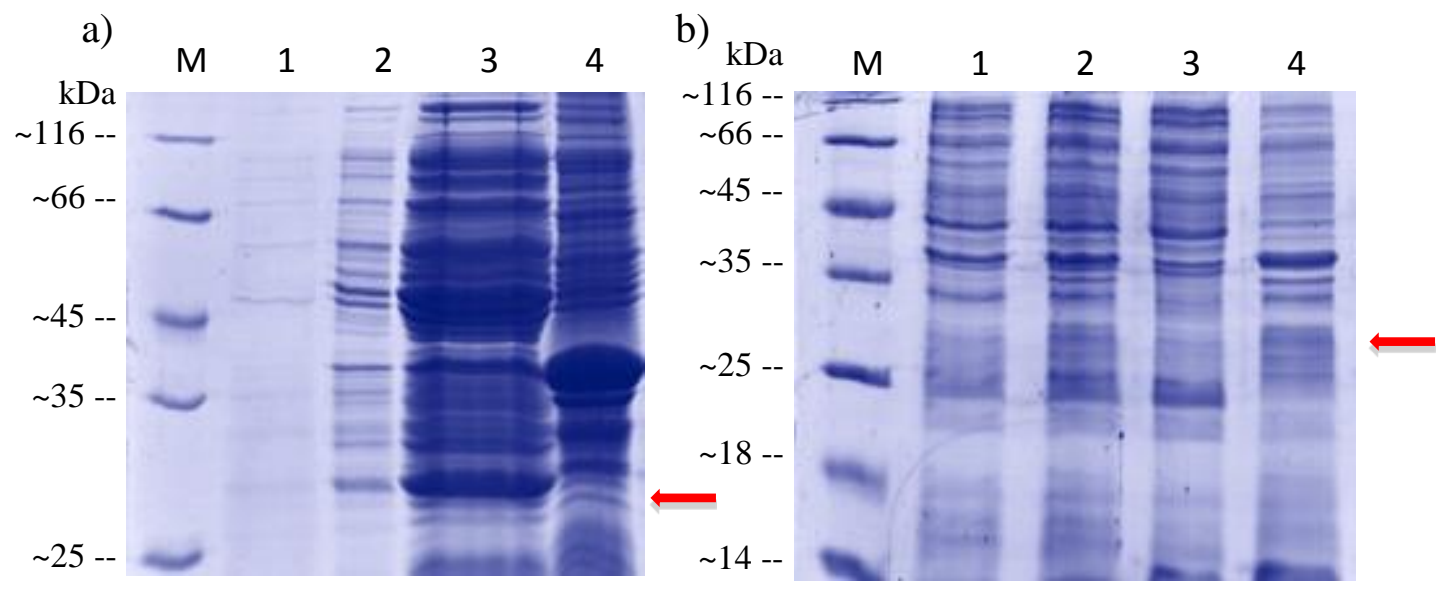

Fonte: Autoria própria.

Paralelamente, análises por Western Blot revelaram a inatividade de qualquer destas bandas da Figura 11 em relação ao anticorpo anti His-tag (dados não mostrados). De acordo com os resultados obtidos optou-se por trabalhar somente com a BL21(DE3), para que os parâmetros e as condições de lise e solubilidade fossem avaliados.

\subsubsection{Ensaio de solubilidade da proteína recombinante FRa em $E$. coli}

A primeira tentativa de solubilização da proteína recombinante foi a variação do tampão de lise. Inicialmente foi utilizado o tampão de lise I (PBS 1×) e, em seguida, a solubilidade em tampão de lise II ( $25 \mathrm{mmol} \mathrm{L}^{-1}$ Tris-HCl; $20 \mathrm{mmol} \mathrm{L}^{-1}$ de $\mathrm{NaCl}$ e $5 \%$ (v/v) de glicerol, pH 7,8). 
Figura 10 - Perfil eletroforético em gel SDS-PAGE 15\%. Teste de solubilidade da $\mathrm{rFR} \alpha$ expressa em BL21(DE3) a $30{ }^{\circ} \mathrm{C}$ por $5 \mathrm{~h}$, com diferentes tampões de lise, I e II. Canaletas: M. Padrão de tamanho molecular (Fermentas); 1 e 2. Conteúdo proteico antes e após a indução, respectivamente; 3 e 5: Frações solúveis do lisado celular; 4 e 6 . Frações insolúveis do lisado celular, com os tampões I (PBS 1×) e II (5\% glicerol), respectivamente. As bandas indicadas com setas representam a $\mathrm{rFR} \alpha, \operatorname{com} 28,3 \mathrm{kDa}$.

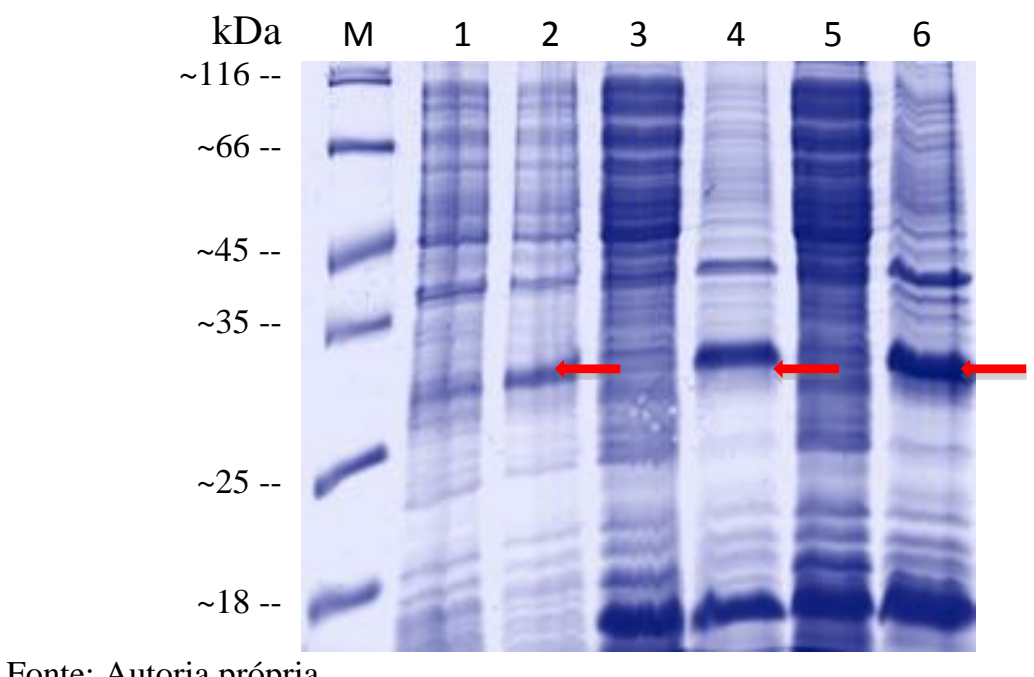

Fonte: Autoria própria.

Analisando-se a Figura 12 é possível concluir que independentemente dos tampões de lise testados, a proteína foi expressa na fração insolúvel do lisado celular. Levando em conta a possibilidade de que as condições de lise estivessem influenciando na solubilidade da proteína recombinante, foram realizados ensaios variando-se estas condições. Contudo, análises por Western Blot confirmaram a ausência da proteína recombinante em todos os sobrenadantes, nas diferentes condições testadas.

Tendo em vista a insolubilidade da proteína recombinante, estudos de solubilidade em condições desnaturantes foram realizados utilizando-se protocolos de re-enovelamento encontrados na literatura. Foi testada a utilização de agentes caotrópicos $8 \mathrm{mmol} \mathrm{L}^{-1}$ de uréia e $6 \mathrm{mmol} \mathrm{L}{ }^{-1}$ guanidina, além do protocolo com 2,4-metil-2-pentanodiol (MPD) descrito por Michaux et al., 2008. (34) Contudo, esses experimentos não se mostraram eficientes uma vez que na etapa de retirada dos agentes de re-enovelmento, ocorreu a precipitação da proteína recombinante (dados não apresentados). 


\subsection{Clone pRSETaTF-FOLR1}

Como alternativa para a insolubilidade da proteína $\mathrm{rFR} \alpha$, optou-se por testar a expressão da proteína em estudo em fusão com a proteína Trigger factor (TF) de E. coli. Trata-se de uma proteína associada à ribossomo que auxilia no enovelamento correto de cadeias polipeptídicas recém sintetizadas. O vetor modificado pRSETa clonado com TF de $E$. coli foi preparado e doado pelo Prof. Dr. Gerhard Wunderlich, Laboratório de Biologia Molecular, do Departamento de Parasitologia, ICB-USP, cuja colaboração viabilizou este experimento. A construção desenvolvida, quando em fase de leitura, possibilita a expressão da proteína em estudo (FR $\alpha$ ) com a TF, auxiliando na solubilidade e na capacidade de folding da proteína clonada. (38)

\subsubsection{Amplificação do FOLR1 e clonagem no vetor modificado pRSETaTF}

A clonagem do DNA codificante da proteína FR $\alpha$ no vetor modificado pRSETaTF foi confirmada através de análise de restrição (Figura 13), PCR (Figura 14) e sequenciamento (Figura 15). Para a análise de restrição, a confirmação da clonagem seria baseada na presença de um inserto de $\sim 1261$ pb formado a partir da digestão com EcoRI (conforme a Figura 13). Ainda, a amplificação do fragmento de DNA correspondente ao FOLR1 foi observada, Figura 14. Ao alinhar-se a sequência proveniente do sequenciamento do clone pRSETaTF-FOLR1 e a sequência de DNA que codifica a proteína FR $\alpha$, Figura 15, é possível observar 95,4\% de identidade, comprovando a presença do inserto FOLR1 no DNA recombinante analisado. Para o alinhamento, foi utilizado o programa LALIGN, Expasy. 
Figura 11 - Perfil eletroforético da reação de análise por restrição do clone pRSETaFOLR1 com a enzima EcoRI em gel de agarose 1\%. Canaleta M: Padrão de DNA 1 kB GeneRuler (Thermo Scientific). 1: pRSETaTF-FOLR1 digerido com EcoR1. Em destaque a banda referente ao inserto de $1236 \mathrm{pb}$.

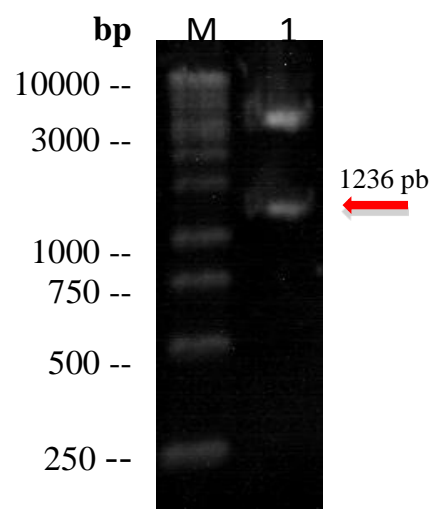

Fonte: Autoria própria.

Figura 12 - Perfil eletroforético da PCR com o clone pRSETaTF-FOLR1 como DNA molde, em gel de agarose 1\%. Canaleta M. Padrão de DNA 1 kB GeneRuler (Thermo Scientific); 1. Controle negativo; 2. PCR com pRSETaTF-FOLR1. Em destaque o segmento de 723 pb, o DNA amplificado.

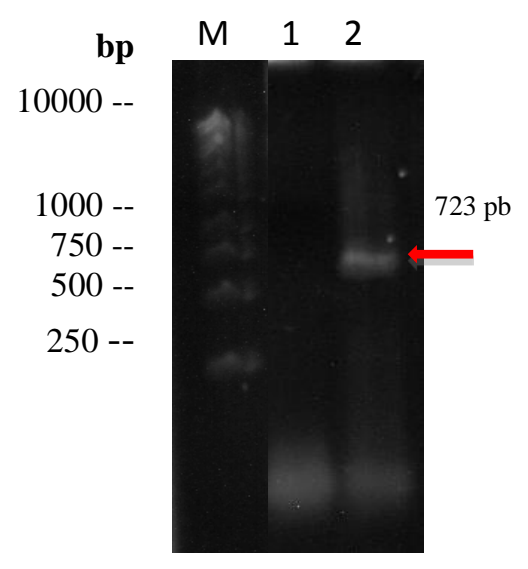

Fonte: Autoria própria. 
Figura 13 - Alinhamento da sequência proveniente da análise por sequenciamento do clone pRSETaTFFOLR1 com a sequência de DNA codificante da proteína FR $\alpha$.

\section{lalign output for Resultado sequenciamento pRSETaTF-FOLR1 vs. FRa}

[EMBnet-Server] Date: Thu Sep 11 5:19:42 2014

LALIGN finds the best local alignments between two sequences version 2.1u09 December 2006 Please cite: $\mathrm{X}$. Huang and W. Miller (1991) Adv. Appl. Math. 12:373-381 alignments < E( 0.05):score: -1 (1 max)

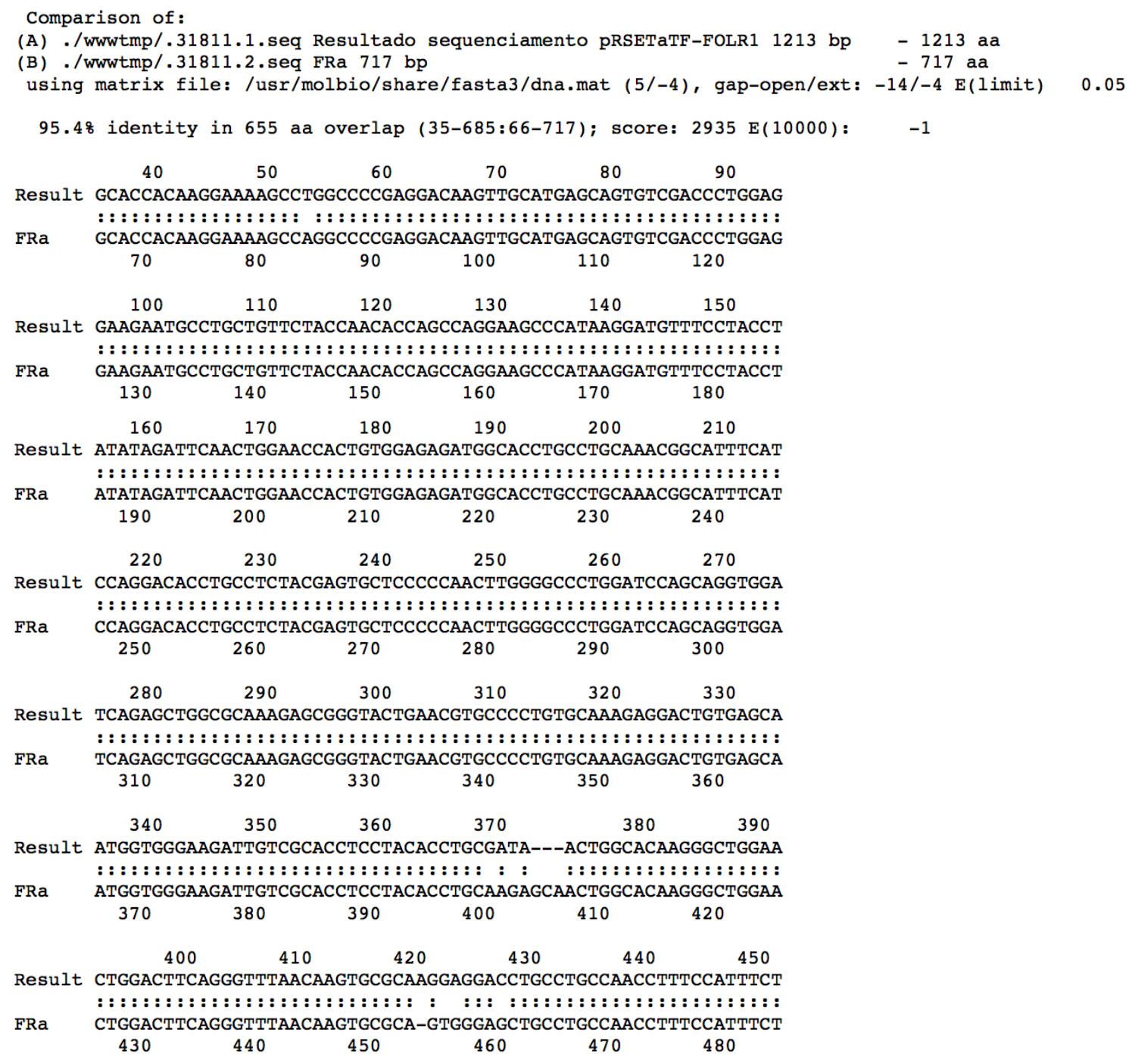




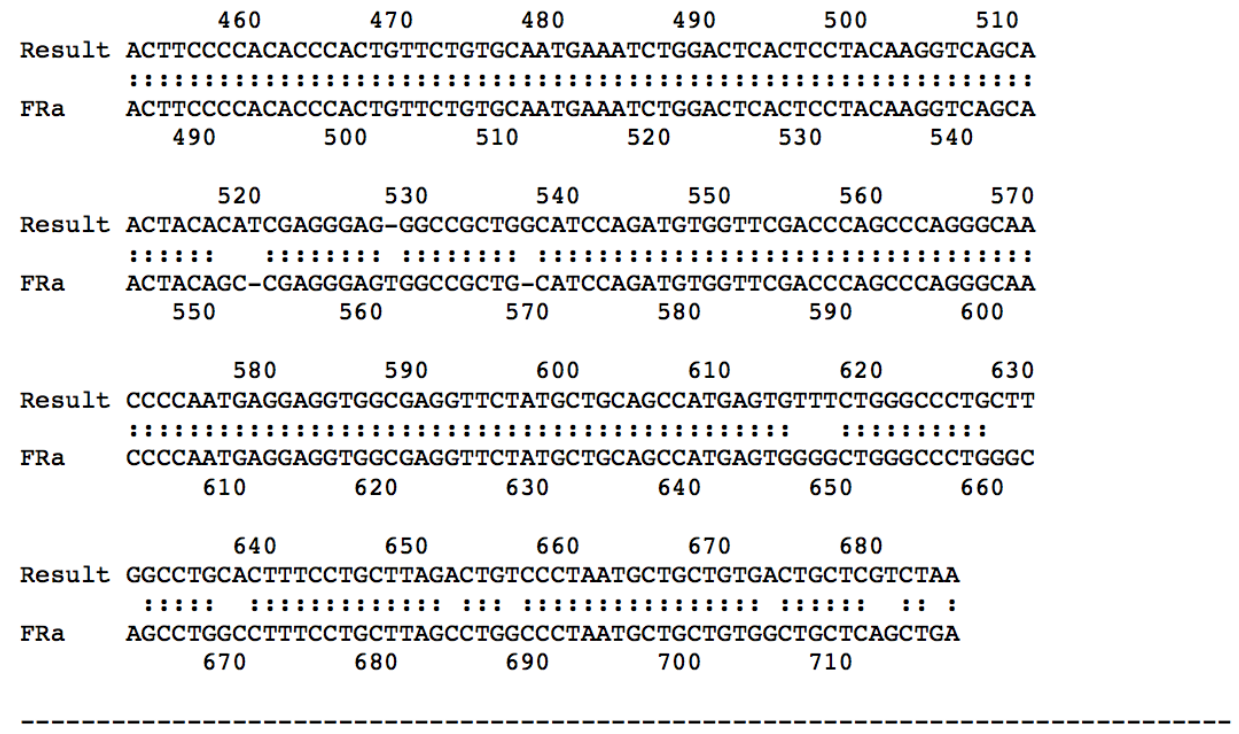

Fonte: Autoria própria com auxílio do software LALIGN.

\subsubsection{Expressão e ensaio de solubilidade da proteína recombinante TFFR $\alpha$}

Uma vez confirmada a clonagem, foram iniciados os testes de expressão e solubilidade da proteína recombinante TF-FR $\alpha$. Conforme pode ser observado no esquema da Figura 16 a proteína recombinante passa a ter $\sim 78 \mathrm{kDa}$. De acordo com a Figura 17 a proteína recombinante rTFFR $\alpha$ foi encontrada na fração solúvel do lisado celular e foi purificada por cromatografia por afinidade, apesar de esta técnica não ter se mostrado muito efetiva. Os dados foram confirmados através da análise por Western Blot, os quais podem ser observados no item b) da mesma Figura.

Figura 14 - Esquema representativo do novo tamanho esperado da proteína recombinante TFFR $\alpha$.

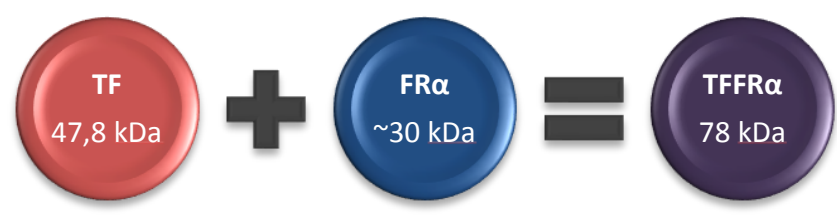

Fonte: Autoria própria. 
Figura 15 - Análise da expressão da TFFR $\alpha$ em BL21(DE3) RIL a $37{ }^{\circ} \mathrm{C}$ por $5 \mathrm{~h}$. a) Perfil eletroforético em gel SDS-PAGE 10\%; b) Filme fotográfico obtido pela revelação do Western Blot, detecção secundária com Kit SuperSignal West Pico Chemiluminescent Substrate, Thermo Scientific. Canaletas M. Padrão de tamanho molecular Spectra ${ }^{T M}$ Multicolor Broad Range (Thermo Scientific); 1. Fração solúvel do lisado celular; 2. Eluição da coluna de Ni; PBS $1 \times+250 \mathrm{mM}$ Imidazol; 3 e 4: Amostras de TF positivas com 6xHis-tag, como forma de controle: Expressão e eluição, respectivamente. Em destaque a banda referente à TFFR $\alpha$ na amostra purificada.

a)

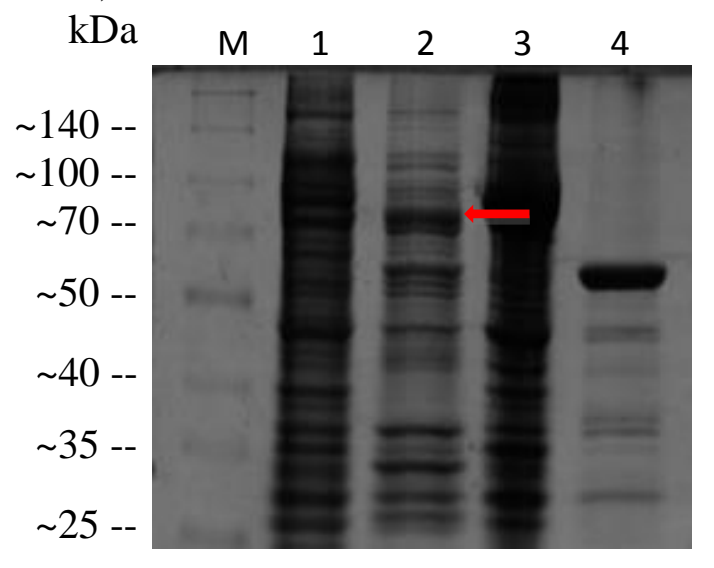

b) $\mathrm{kDa}$

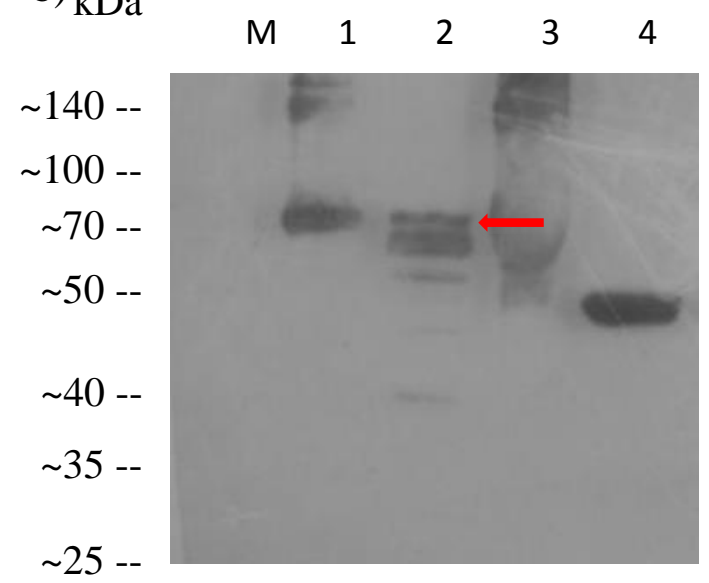

Fonte: Autoria própria.

Visando concentrar e purificar a amostra, foram utilizadas colunas de concentração e dessalting, respectivamente. Através de análises de quantificação de proteína pelo método Bradford, observou-se a perda de proteína ao se utilizar a coluna dessalting, o que foi confirmado através de análise do gel de acrilamida apresentado na Figura 18. Desta forma, optou-se por não mais utilizar a coluna dessalting, e sim, uma diálise contra tampão PBS 1×, $500 \mathrm{mmol} \mathrm{L}^{-1} \mathrm{NaCl}$, como alternativa para a retirada do imidazol, o que proporcionou uma concentração de $2,24 \mathrm{mg} / \mathrm{mL}$ de TF-FR $\alpha$. 
Figura 16 - Análise de concentração e purificação da TFFR $\alpha$. a) Perfil eletroforético em gel SDS-PAGE 10\%; b) Filme fotográfico obtido pela revelação do Western Blot, detecção secundária com Kit SuperSignal West Pico Chemiluminescent Substrate, Thermo Scientific. Canaletas: M. Padrão de tamanho molecular Spectra ${ }^{T M}$ Multicolor Broad Range (Thermo Scientific); 1. Fração eluida da coluna de concentração; 2. Fração concentrada pela coluna; 3. Fração eluída da coluna dessalting; 4. Eluição do controle positivo de TF em fusão. Em destaque a banda referente à TFFR $\alpha$, podendo ser observadas bandas referentes à esta proteína truncada.

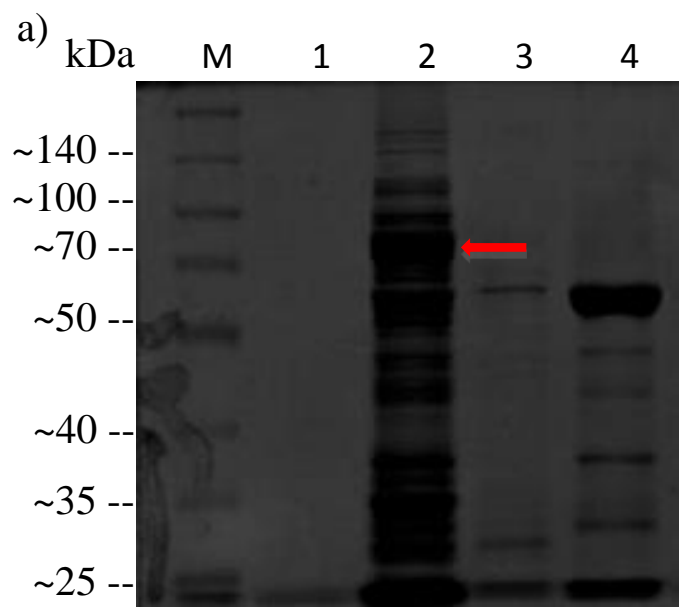

b)

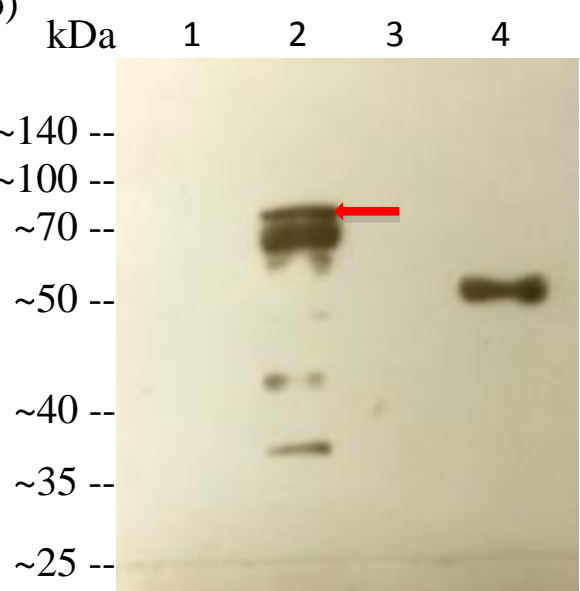

Fonte: Autoria própria.

\subsection{Análises de OFFGEL}

Com o objetivo de promover uma melhor purificação da proteína recombinante para identificação posterior em espectrômetro de massas, foi promovido um fracionamento no OFFGEL, o que promoveu a separação de proteínas que partilham da mesma massa molecular, porém que apresentam pIs diferentes. Após $48 \mathrm{~h}$ de focalização pode ser observada essa separação, conforme mostra a Figura 19, que foi complementada por Western Blot (Figura 19 c), corroborando com dados anteriores que comprovaram a presença da TF-FR $\alpha$ em solução. A TFFR $\alpha$ faz-se presente nos poços 4 - 6 (faixa de $\mathrm{pH}$ médio esperado 5,03 6,19) da Figura 19, o que concorda com os pIs de cada proteína TF $\sim 4,88$ e FR $\alpha \sim 7,0$, respectivamente. As amostras foram submetidas à digestão em solução com tripsina para análise por espectrometria de massas. 
Figura 17 - Análise de OFF-GEL da amostra pré-purificada por cromatografia de afinidade. a) Perfil eletroforético em gel SDS-PAGE 12,5\% das frações dos compartimentos 1-11 sobre fita IPG de pH 3-10. Detalhe comparando o perfil eletroforético em gel das frações 5 e 6 (b) com o filme fotográfico obtido pela revelação do Western Blot, detecção secundária com Kit SuperSignal West Pico Chemiluminescent Substrate, Thermo Scientific (c).

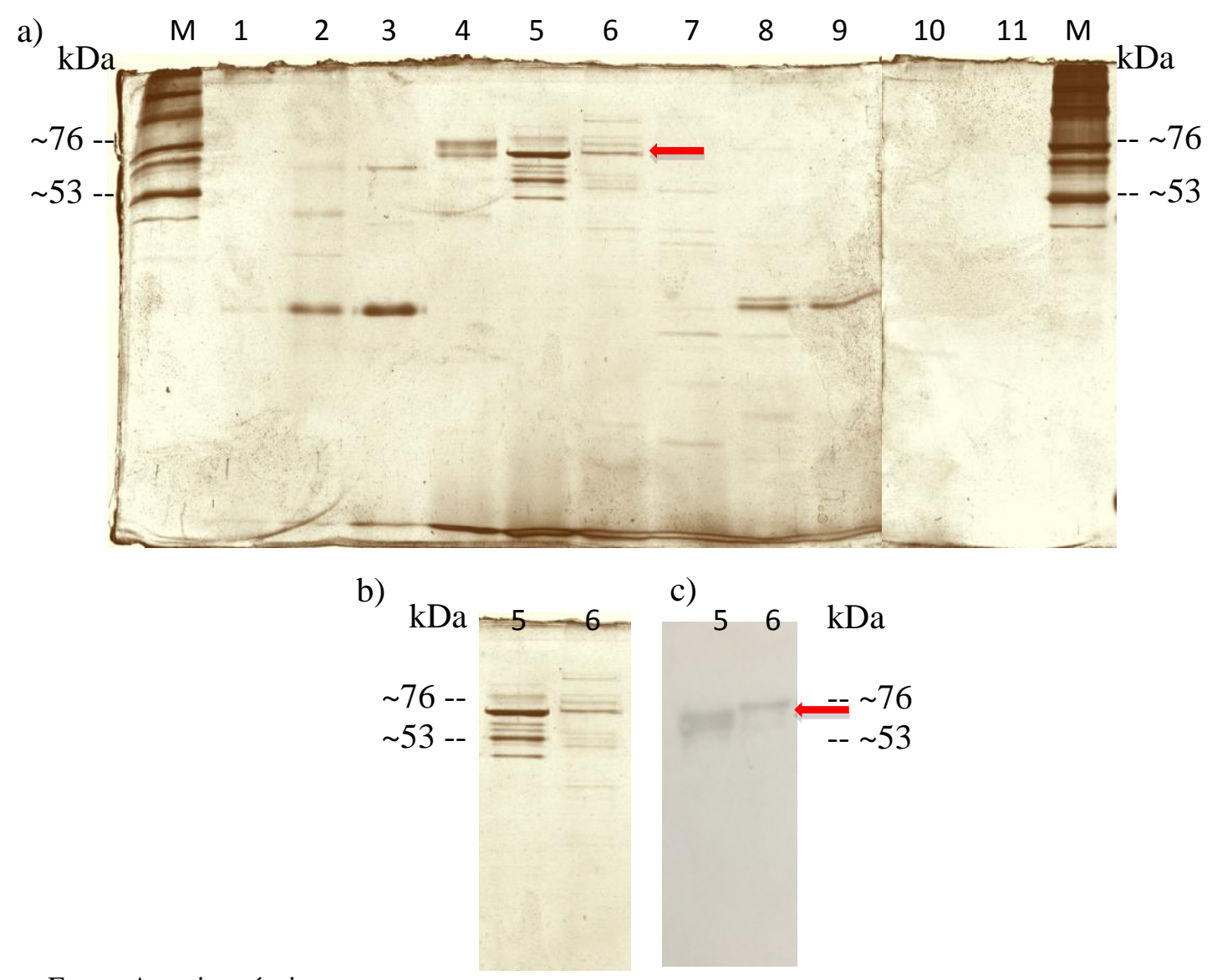

Fonte: Autoria própria.

\subsection{Análise de massas}

A análise por espectrometria de massas foi promovida com o intuito de se confirmar a presença e a identidade da proteína TFFR $\alpha$. A partir do cromatograma obtido (Figura 20) para a banda referente à TFFR $\alpha$ de $\sim 78 \mathrm{kDa}$, ou seja, TF em fusão com o FR $\alpha$, foi realizada a análise de massas dos peptídeos e o tratamento dos dados utilizando-se o software SEQUEST. 
Figura 18 - Cromatograma do digerido triptico da banda referente à TFFR $\alpha(\sim 78$ kDa) após pré-purificação em coluna de Ni. As condições cromatográficas utilizadas foram descritas no ítem 1.11.4

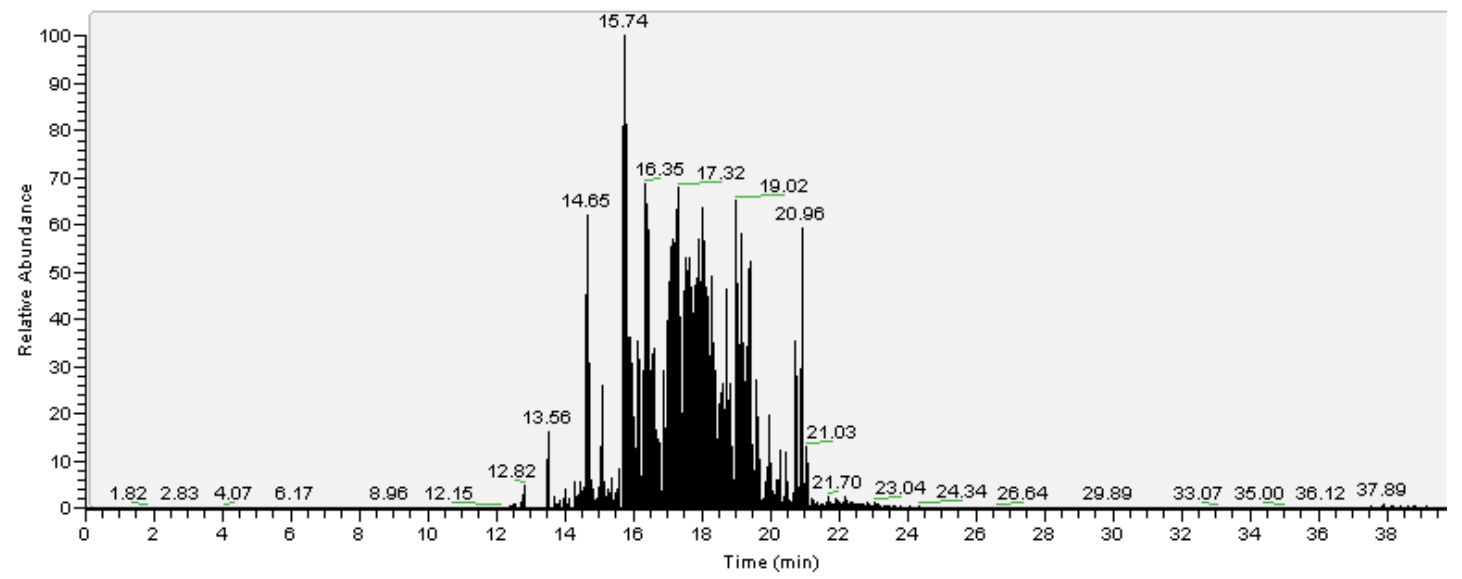

Fonte: Autoria própria com auxílio do software XCalibur, versão 2.0.7 (Thermo Fisher Scientific).

Conforme esperado, foi confirmada a presença da proteína recombinante Trigger factor de E. coli, com massa de 47,8 kDa na amostra referente à banda de $\sim 78 \mathrm{kDa}$ extraída do gel, sendo a proteína em maior quantidade, representando $54,55 \%$ de cobertura (20 peptídeos, sendo 2 únicos) e pI teórico calculado de 4,88. No entanto, a detecção e reconhecimento de peptídeos da proteína FRa não foi possível através do software SEQUEST. Alguns fatores durante a digestão das amostras ou processamento dos dados podem ter contribuído para a ineficiência da identificação. Outra possibilidade seria que, durante o processo de digestão, foram produzidos pequenos fragmentos de peptídeos que teriam sido perdidos durante a etapa de limpeza da amostra. Baixa concentração de proteínas presentes nas bandas podem ter, ainda, contribuído para contaminação da amostra e ineficiência na identificação.

Como alternativa, optou-se por uma comparação direta entre os resultados de uma digestão virtual da proteína TF-FR $\alpha$, que foi promovida através da plataforma virtual PeptideCutter, Expasy, (Figura 21) e os peptídeos obtidos experimentalmente, e os resultados foram tratados através do software SEQUEST. Esta abordagem, baseada na sequência dos aminoácidos, peptide fragmentation fingerprinting (PFF), proporciona uma determinação mais específica das proteínas, uma vez que não leva em consideração somente a massa do fragmento, como a metodologia peptide mass fingerprinting (PMF). (39) 
A banda referente a $\sim 78 \mathrm{kDa}$ foi analisada em duplicata, onde foram encontrados 3 peptídeos comuns da FR $\alpha$ em cada amostra, totalizando 5 peptídeos reconhecidos (duplicata, sendo 1 comum entre as amostras). Estes peptídeos estão marcados na Figura 21 e descritos na Tabela 2.

Figura 19 - Resultado da digestão tríptica da proteína recombinante TF-FR $\alpha$, sendo mostrada apenas o resultado da digestão referente somente à porção do receptor. Em destaque os peptídeos encontrados (amarelo) e o início da proteína FR $\alpha$ (seta azul).
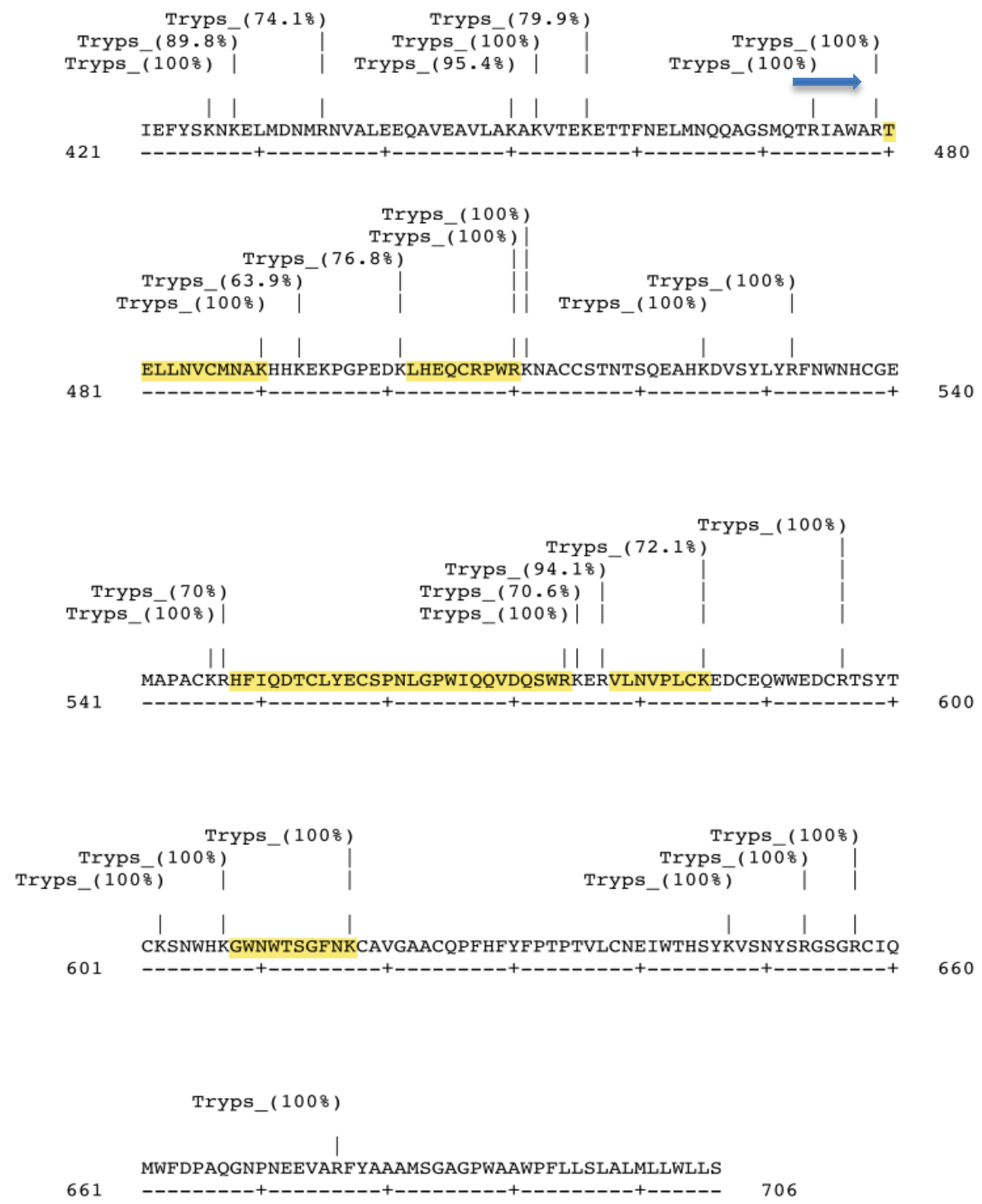

Fonte: Autoria própria com auxílio do software PeptideCutter, Expasy. 
Tabela 2 - Lista dos peptídeos comuns da FR $\alpha$ entre o experimento de digestão com tripsina real e o virtual.

\begin{tabular}{cccccc}
\hline Peptídeo & $\begin{array}{c}\text { Amostra } \\
\mathbf{7 8 ~ k D a}\end{array}$ & SpScore & Xcorr & Carga & $\Delta$ Cn \\
& $(1)$ & 635,44 & 2,06 & 2 & 0,2398 \\
\hline TELLNVCMNAK & $(2)$ & 534,81 & 1,96 & 3 & 0,000 \\
LHEQCRPWR & $(2)$ & 183,87 & 1,41 & 2 & 0,000 \\
HFIQDTCLYECSPNLG & & & & & \\
PWIQQVDQSWR & $(1)$ & 397,65 & 2,39 & 2 & 0,000 \\
VLNVPLCK & $(1)$ & 1134,48 & 2,46 & 2 & 0,000 \\
GWNWTSGFNK & $(2)$ & 811,01 & 2,17 & 2 & 0,2619 \\
\hline
\end{tabular}

Os critérios para a escolha dos parâmetros a serem utilizados para uma identificação confiável das proteínas são bastante controversos. O primeiro parâmetro analisado pelo SEQUEST, por exemplo, é o SpScore, um score preliminar para cada sequência de aminoácidos, que leva em conta o número de íons no espectro MS/MS que correlacionam com os dados experimentais. Apenas espectros com um determinado SpScore são analisados, de forma que, quanto maior, melhor. (40) Analisando-se os dados da Tabela 2 é possível observar que praticamente todos os peptídeos em destaque se encaixam neste parâmetro, sendo que todos foram analisados pelo SEQUEST.

Alguns trabalhos utilizam também o Xcorr (cross-correlation value), parâmetro numérico derivado da sobreposição entre o espectro teórico de cada sequência obtida no banco de dados, e o espectro experimentalmente obtido. (41) Indícios de uma boa correlação são obtidos para valores de Xcorr > 2,0, sendo maior para peptídeos maiores e com boas correlações. (40) Ainda é necessária a avaliação de um segundo score, classificado como $\Delta \mathrm{Cn}$ (Delta Correlation number), que contribui para a confiabilidade do resultado, sendo definido como a diferença entre os valores de Xcorr obtidos para a sequência de aminoácidos de maior Xcorr e a sequência seguinte. De forma geral, os critérios utilizados para classificar uma 
determinação como satisfatória ou não, são: Xcorr > 3,75 para peptídeos com carga +3 ; Xcorr $>$ 2,2 para peptídeos com carga +2 e Xcorr > 1,9 para peptídeos com carga +1 . (41)

Analisando-se os dados obtidos para os peptídeos em análise descritos na Figura 21, o único parâmetro que não está de acordo com os critérios comumente utilizados pela literatura é o $\Delta \mathrm{Cn}$. De modo geral, $\Delta \mathrm{Cn}>0,1$ é considerado bom, contudo, quando se utiliza um banco de dados grande para comparação, os valores de $\Delta \mathrm{Cn}$ podem ser bem menores do que aqueles obtidos quando comparados à um banco de dados pequeno. Isso explica os valores nulos observados na tabela, uma vez que, quanto maior o banco de dados, maior a chance de se encontrar similaridade entre sequências peptídicas. (40)

De acordo com a abordagem PMF, de 4 a 6 peptídeos (700-3000 Da) provenientes de sua clivagem caracterizam uma proteína. (39) Levando em consideração que a metodologia de análise PFF é mais confiável, pode-se supor que o resultado obtido neste experimento confirma a presença da FR $\alpha$ em fusão com a TF. No entanto, novos experimentos deverão ser feitos para confirmar estes resultados.

\subsubsection{Testes de afinidade}

A afinidade da proteína recombinante ao ligante tetrahidrofolato (Sigma Aldrich) foi analisada em MECQ. Através desta técnica foi observada uma variação de massa com o emprego de medida da variação de frequência, $\Delta f$, tanto nas amostras do extrato proteico nativo quanto no recombinante. 
Figura 20 - Eletrólito suporte tampão fosfato $0,2 \mathrm{~mol} \mathrm{~L} \mathrm{~L}^{-1}, \mathrm{pH} 7,2$. Adição de $1 \mathrm{~mL}$ da solução de tetrahidrofolato em $80 \mathrm{~mL}$ do eletrólito suporte. Experimento conduzido em OCP (potencial de circuito aberto) sob agitação magnética constante.

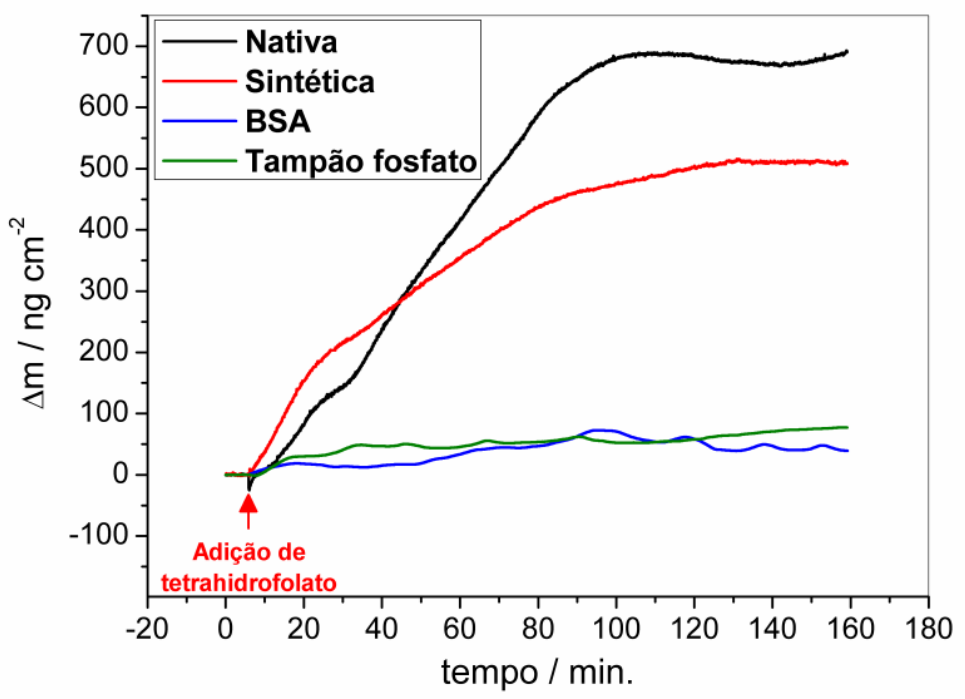

Fonte: Autoria própria com auxílio do software Origin.

Como pode ser observado na Figura 22 ambas amostras proteicas apresentaram variação positiva de massa quando adicionado o ligante tetrahidrofolato. Uma variação maior foi observada na amostra contendo FR $\alpha$ nativa (extrato de GPIs), o que pode ser explicado pela maior quantidade de proteínas, além da provável presença de outros receptores de folato. Esse experimento comprova a atividade do receptor recombinante, dando fortes indícios de que a construção com a proteína TF realmente contribuiu com a solubilidade do receptor por auxiliar no enovelamento correto do mesmo. Conforme descrito na literatura, para que a ligação ao folato ocorra é necessária a existência das ligações dissulfeto. $(9,16,17)$ Por outro lado, as glicosilações são necessárias somente para a atividade de internalização do folato, o que não compromete a utilização da TF-FR $\alpha$ para os objetivos propostos neste trabalho. Essa é a primeira descrição de expressão do $\mathrm{FR} \alpha$ em sistema de expressão procariótico com a manutenção da afinidade do receptor com o ligante testado, tetrahidrofolato.

\subsubsection{Testes de imobilização da TFFR $\alpha$ em lipossomo}

A metodologia descrita por Colhone et al. (2009) foi empregada para a produção de lipossomos, a qual utiliza ultrassonicação como indutor de produção das vesículas. Essa 
técnica proporciona a produção de lipossomos de tamanhos diferentes (geralmente em torno de $100 \mathrm{~nm}$ ), sendo difícil a separação precisa. (30) No entanto, acredita-se que seja uma alternativa para estudos iniciais com biodetectores. Outra alternativa que pode possibilitar a separação confiável seria o emprego de técnicas de produção envolvendo microfluídica, iniciada durante o estágio de pesquisa no exterior (BEPE), que envolve a metodologia de produção descrita por Arriaga et al. (2013). No entanto, não foi possível a finalização desta construção em função de estrutura/equipamento laboratorial.

Figura 21 - Análise da diálise e ligação da TFFR a lipossomos. a) Perfil eletroforético em gel SDS-PAGE 10\%; b) Filme fotográfico obtido pela revelação do Western Blot, detecção secundária com Kit SuperSignal West Pico Chemiluminescent Substrate, Thermo Scientific. Canaletas: M. Padrão de tamanho molecular Spectra ${ }^{T M}$ Multicolor Broad Range (Thermo Scientific); 1. Amostra TFFR $\alpha$ purificada e dialisada; 2. Sobrenadante dos lipossomos NTA; 3. Lipossomo sem Ni; 4. Lipossomo com Ni; 5. Amostra TFFR $\alpha$ purificada em coluna de Ni.

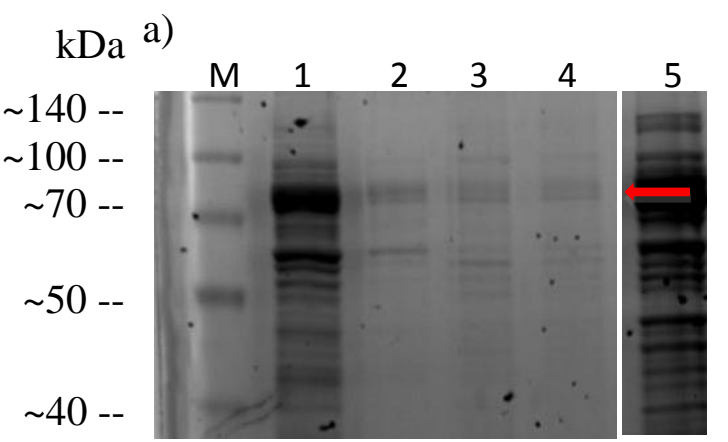

b)

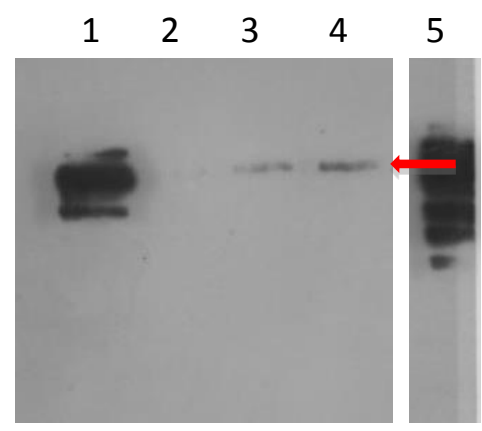

Fonte: Autoria própria.

Conforme pode ser observado na Figura 23, a etapa de diálise possibilitou uma nova forma de purificação da amostra, além da coluna de níquel. No âmbito dos lipossomos, notase que a imobilização da proteína recombinante, além de efetiva, promoveu a seleção da proteína recombinante completa (não truncada). Provavelmente, aquela que continha o receptor completo pode ter sido favorecida por conta de sua estrutura terciária, globular e um microambiente similar àquele da membrana celular. 
Ainda, a intensidade da banda referente à TF-FR $\alpha$ imobilizada no lipossomo sem NTA, em $\sim 78 \mathrm{kDa}$, é aproximadamente $35 \%$ menor em relação à amostra com lipossomoNTA, como mostram os gráficos de intensidade de bandas na Figura 24, diferença que poderia ser ainda maior no caso da utilização de uma ultra-centrífuga para concentrar os proteolipossomos. Esses dados comprovam a efetividade da construção lipossômica niquelada para a incorporação de proteínas em fusão com uma cauda de histidina.

Figura 22 - Intensidade das bandas observadas nos poços 2, 3 e 4 do Western Blot da Figura 23.

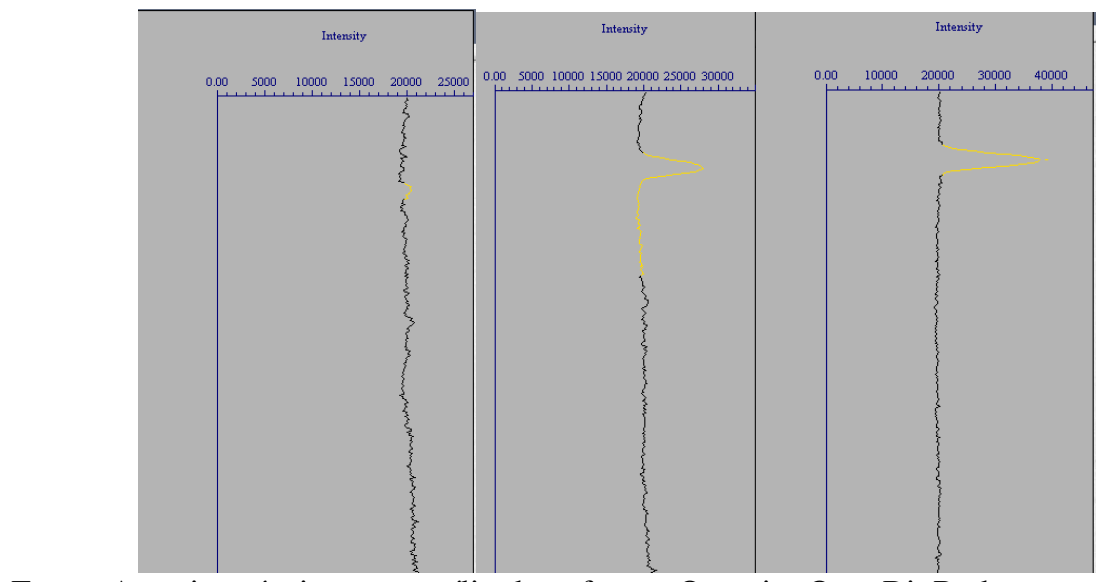

Fonte: Autoria própria com auxílio do software Quantity One, BioRad.

\subsection{Caracterização morfológica dos proteolipossomos}

Por conta da estabilidade dos lipossomos e disponibilidade de equipamentos, análises microscópicas dos proteolipossomos só puderam ser promovidas para as amostras contendo proteínas GPI-ancoradas de células HeLa. A estrutura geral esperada para os proteolipossomos TFFR $\alpha$ é basicamente a mesma daquela observada para os GPIproteolipossomos. Conforme pode ser observado nas Figuras 25 e 26 as construções lipídicas realmente adquirem tamanhos variados quando produzidos pela técnica de sonicação, em geral variando entre 10-25 $\mu \mathrm{m}$. Os resultados da análise morfológica comprova o sucesso na produção dos proteolipossomos. Essas estruturas poderão ser utilizadas para testes em biodetectores de FR $\alpha$. 
Figura 23 - Imagem de microscopia ótica digital dos GPI-proteolipossomos, de células HeLa.

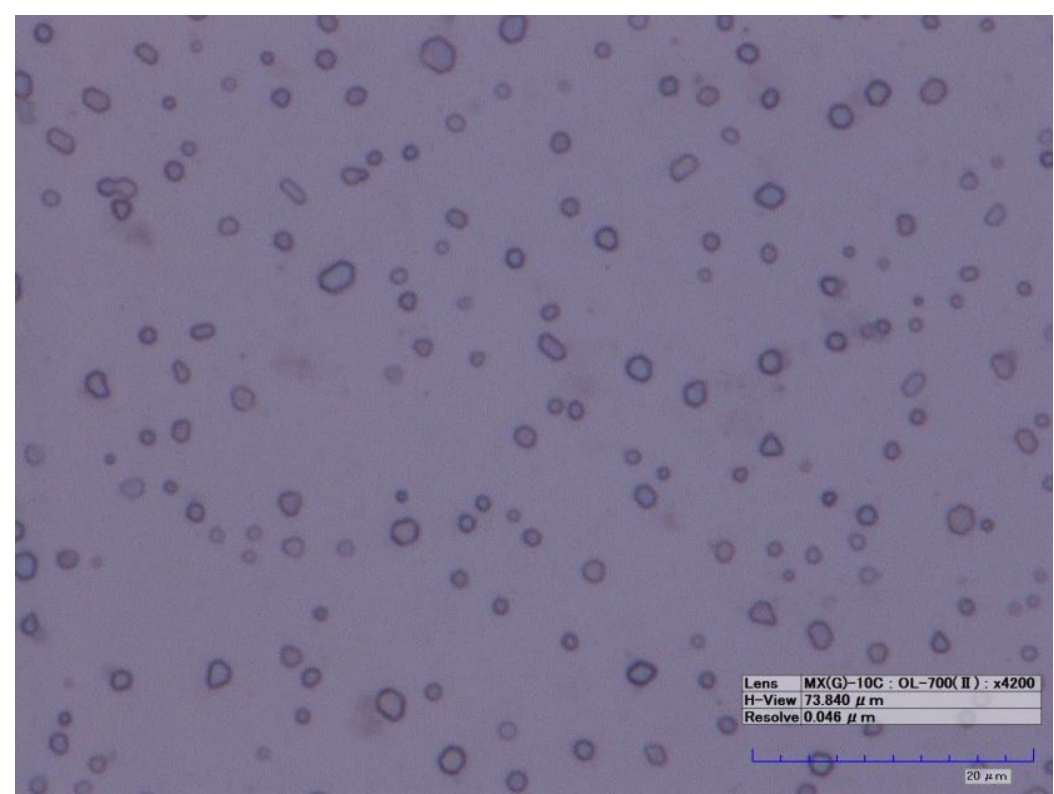

Fonte: Autoria própria. 
Figura 24 - Imagem de microscopia de força atômica (AFM) da amostra de GPI-proteolipossomos dispersa sobre mica e analisada no equipamento de AFM Nanosurf EasyScan 2, $50 \times 50 \mu \mathrm{m}$.
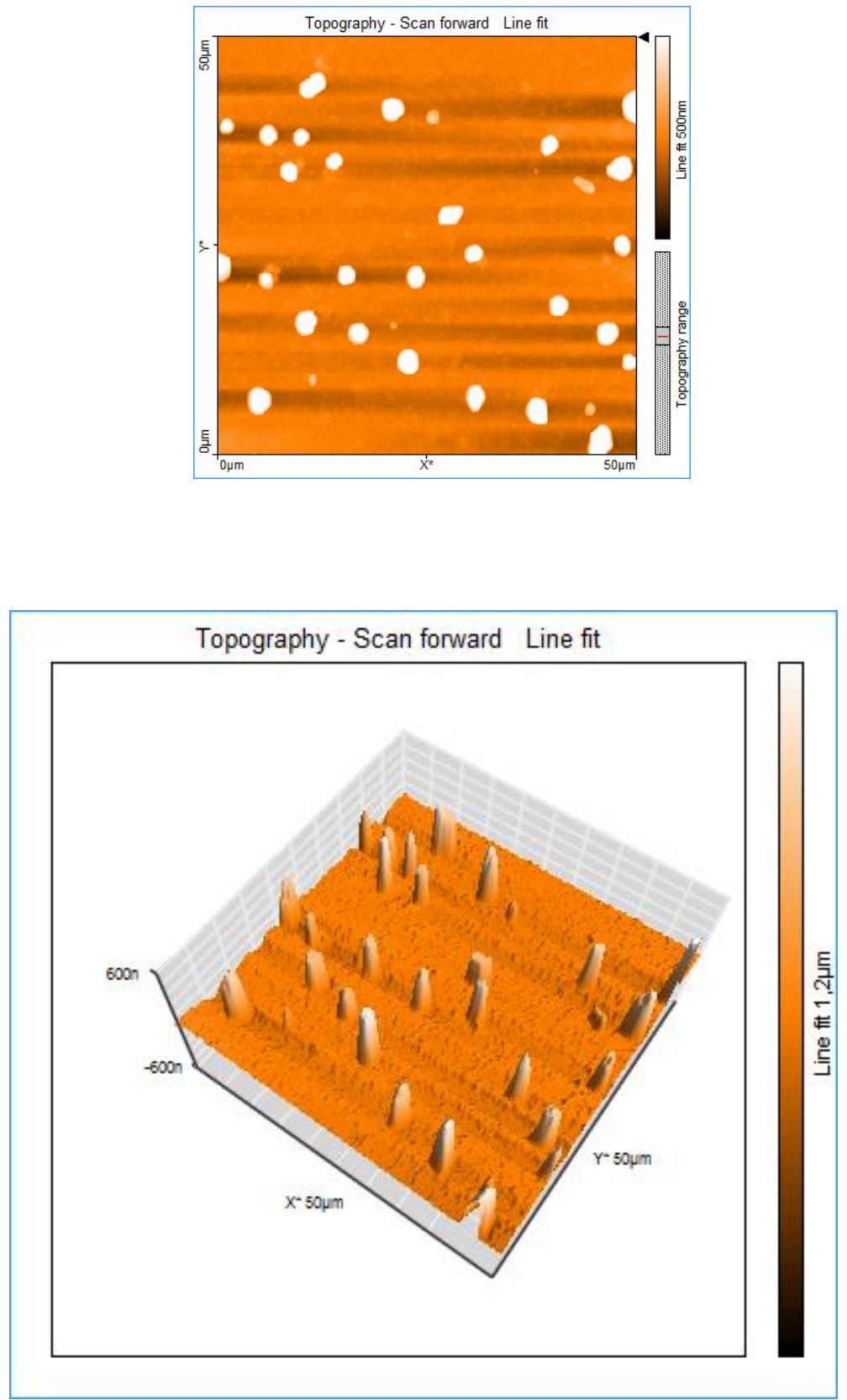

Fonte: Autoria própria. 


\section{Conclusões}

Com o trabalho desenvolvido nesse capítulo foi possível a expressão e purificação da proteína $\mathrm{FR} \alpha$ em fusão com a proteína $\mathrm{TF}$, sendo que esta construção teve alto impacto na solubilidade da proteína recombinante. A pesquisa foi relevante, já que permitiu a imobilização da proteína recombinante em um lipossomo, sendo que não há relatos na literatura da produção deste receptor em E. coli, nem da utilização do mesmo para a imobilização em partículas. $\mathrm{O}$ fato de ser utilizado um sistema de expressão que poderia ser considerado não ideal para a produção da proteína de Homo sapiens, por não permitir glicosilações e não favorecer o correto enovelamento proteico, faz desta pesquisa pioneira e relevante visto que o receptor FR $\alpha$ manteve sua afinidade ao ligante testado.

A identificação da proteína recombinante através de SDS-PAGE seguida de análises por Western Blot, em paralelo com LC-MS/MS, mostrou-se adequada e eficiente para o estudo realizado, sendo consideradas técnicas complementares para a confirmação da presença da TF-FR $\alpha$.

A imobilização do receptor em lipossomos específico foi considerada efetiva. A análise morfológica específica dessas amostras não puderam ser obtidas por questões de logística envolvendo o tempo de produção e disponibilidade do equipamento. Contudo, essas análises serão promovidas e espera-se que se assemelhem aos dados obtidos para os protelipossomos de proteínas GPI-ancoradas extraídas de células HeLa. Novas tentativas de imobilização poderão, ainda, ser promovidas em lipossomos produzidos através de técnicas microfluídicas, aproximando ainda mais os lipossomos de membranas celulares.

Este estudo abre potencial para continuação da produção de padrões analíticos para estudos avançados envolvendo o detector de FR $\alpha$ desenvolvido por Lima et. al., 2010. 


\section{Capítulo 3}

\section{Clonagem, expressão e}

purífícação da $r \mathcal{F R} \alpha$ em $\mathcal{P}$.

pastoris 


\section{Introdução}

Nos últimos anos, o sistema de expressão em Pichia pastoris tem sido bastante utilizado para a produção de inúmeras de proteínas heterólogas. Isto porque este sistema reúne vantagens características dos sistemas de expressão eucarióticos, tais como o processamento de proteínas, modificações pós-traducionais além da simples e relativamente barata manipulação molecular, característica principalmente de sistemas procarióticos como E. coli. Além disso, a utilização do peptídeo sinal fator $\alpha$, na porção N-terminal da construção, irá permitir que a proteína seja secretada, aumentando ainda mais suas vantagens em relação a outros sistemas eucarióticos de expressão. O sistema de $P$. pastoris promove a oxidação do metanol através da álcool oxidase, dando origem a formaldeído e peróxido de hidrogênio, uma vez que se trata de uma levedura metilotrófica. $\mathrm{O}$ fato de essa proteína possuir baixa afinidade com $\mathrm{O}_{2}$ e o mecanismo compensatório encontrado pela célula ser a produção de mais proteína, são exploradas as técnicas de manipulação genética/biologia molecular. Para isso, o promotor da regulação da produção da álcool oxidase é utilizado para regular a expressão da proteína heteróloga, de forma que a expressão da proteína recombinante será induzida através da adição de metanol. (42) O mecanismo de clonagem esta esquematizado na Figura 27. 
Figura 25 - Desenho esquemático do mecanismo de inserção do plasmídeo (contendo o DNA codificante da proteína de interesse) ao DNA genômico da levedura, através do crossover entre o loci e uma das regiões AOX1 do plasmídeo pPICZ $\alpha$ previamente clonado. Eventos de multiplas inserções podem ocorrer.

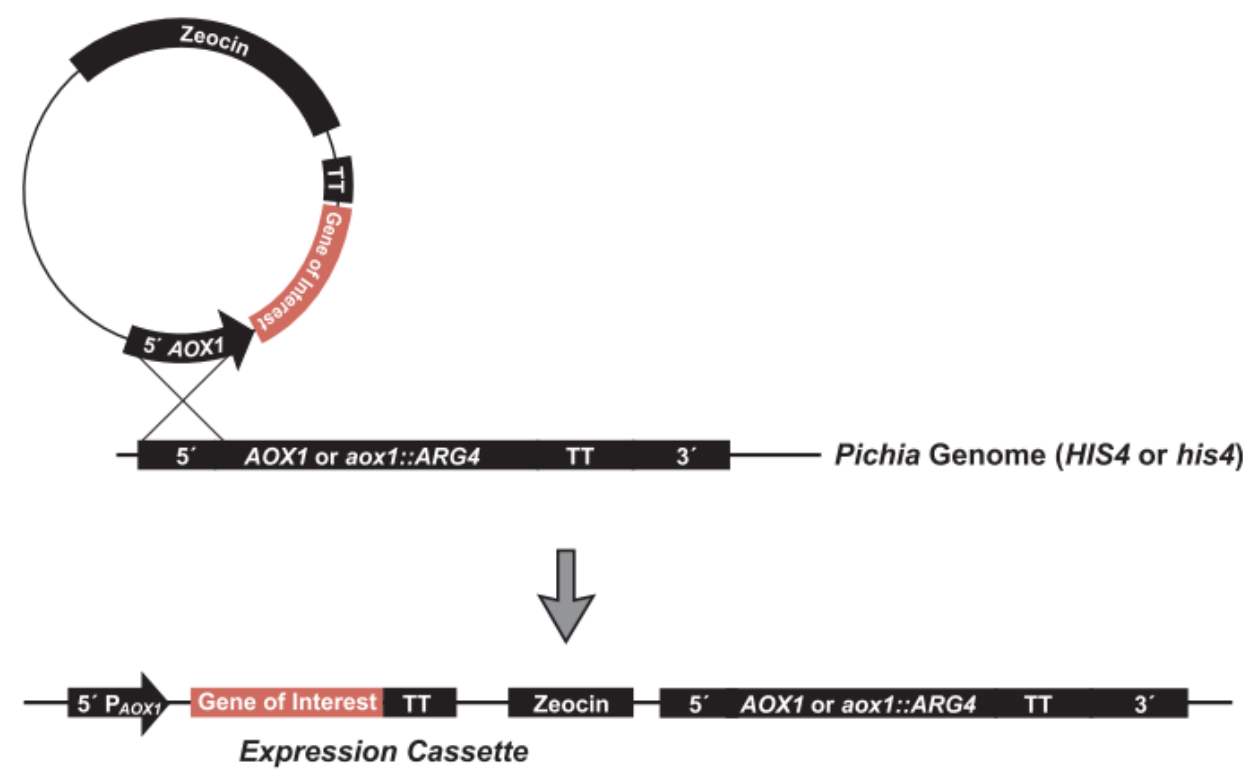

Fonte: LIFE TECHNOLOGIES, 2010, p. 63.

O objetivo deste estudo foi produzir a proteína heteróloga FR $\alpha$, buscando melhores resultados na solubilidade e purificação da proteína recombinante, em relação à estudos anteriores com E. coli. Assim, foi utilizado o vetor comercial pPICZ $\alpha$ A (Life Technologies) previamente clonado com o gene que codifica a expressão da FR $\alpha$, além de uma $6 \times$ His-tag e o fator $\alpha$ de transcrição, na porção $\mathrm{N}$-terminal. Esta construção possibilita a secreção da proteína para o meio extra celular, atuando como uma etapa de purificação inicial, e ainda permite a purificação através de cromatografia por afinidade em coluna de níquel.

Os experimentos citados neste capítulo são relacionados à expressão da proteína recombinante $\mathrm{rFR} \alpha$ em sistema de expressão P. pastoris. No entanto, este sistema de expressão não se mostrou adequado para a produção da proteína recombinante e, mesmo 
assim, os resultados são discutidos neste capítulo para esclarecer e servir como base para estudos futuros.

\section{Materiais e Métodos}

\subsection{Clone pPICZaA-FOLR1}

A estrutura do plasmídeos utilizado para transformar células de $P$. pastoris é mostrada na Figura 28.

Figura 26 - Mapa do vetor pPICZ $\alpha \mathrm{A}$ clonado com o fragmento FOLR1 entre os sítios de restrição das endonucleases EcoRI e NotI. Este inserto codifica a expressão da proteína FR $\alpha$ recombinante em fusão com uma cauda de histidina na porção N-terminal da proteína, além do fator- $\alpha$ de secreção. As setas em destaque referem-se ao gene que codifica a resistência ao antibiótico zeocina e o gene FOLR1 inserido. Software SnapGene.

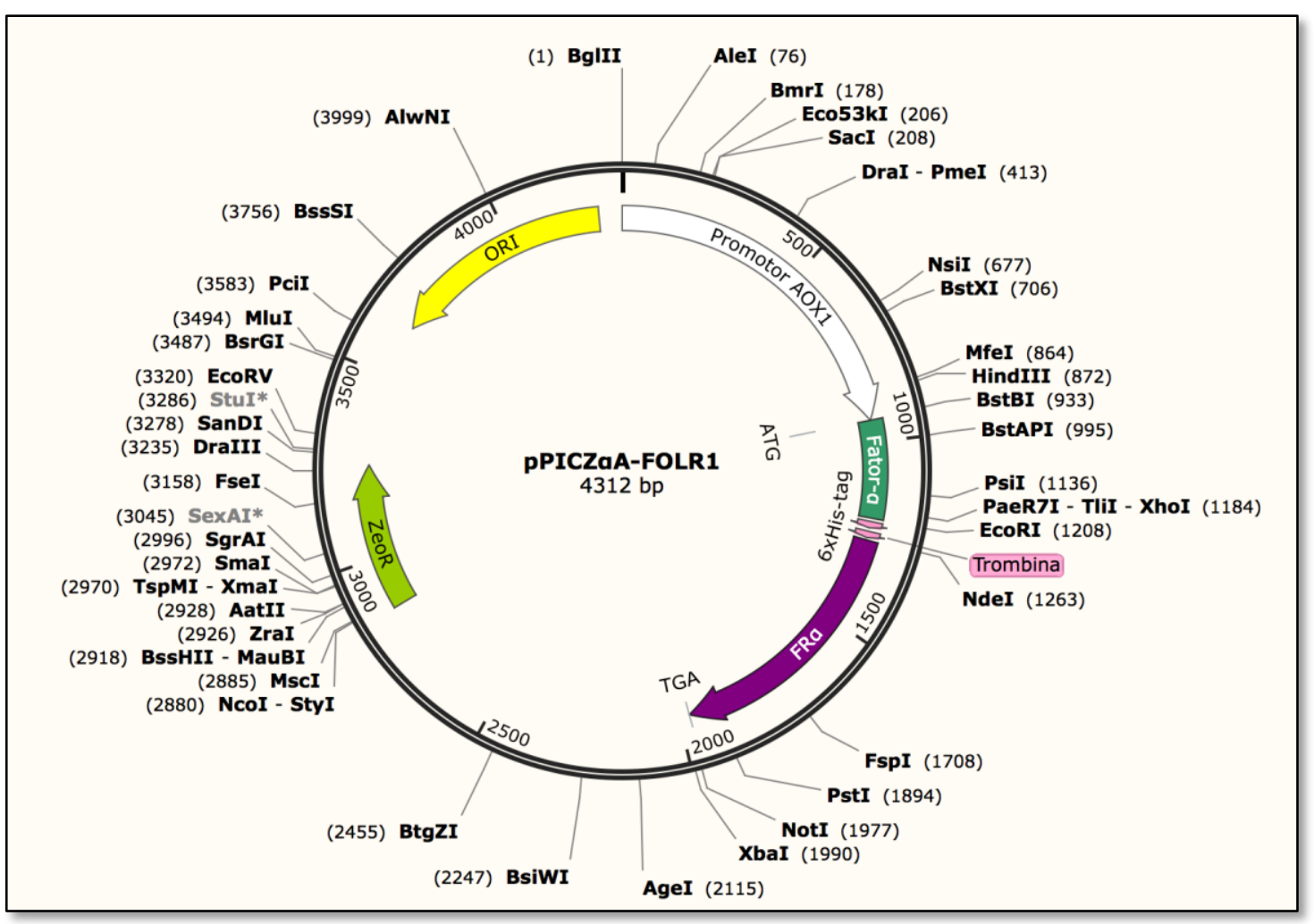


5' agatctaacatccaaagacgaaaggttgaatgaaacctttttgccatccgacatccacaggtccat tctcacacataagtgccaaacgcaacaggagggg

$3^{\prime}$ tctagattgtaggtttctgctttccaact tactttggaaaacggtaggetgtaggtgtccaggtaagagtgtgtattcacggtttgegttgtcetcccc Promotor AOX1

at acactagcagcagaccgtt gcaaacgcaggacctccactcctct tctcctcaacacccact t t gccat cgaaaaaccagcccagt tat tgggct tga

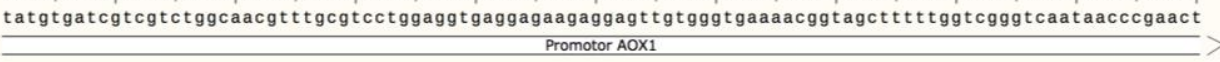

Eco53kI SacI

ttggagctcgctcattccaat tccttctattaggctactaacaccatgact t tat tagcctgtctatcctggccccctggcgaggttcatgtt tgtt ta aacctcgagcgagtaaggttaaggaagataatccgatgattgtggtactgaataatcggacagataggaccgggggaccgctccaagtacaaacaat Promotor AOX1

tttccgaatgcaacaagctccgcat tacacccgaacat cactccagatgagggctttctgagtgtggggtcaaatagtttcatgttccccaaatggccca aaggcttacgttgttcgaggcgtaatgtgggcttgtagtgaggtctactccogaagactcacacccagtt tatcaaagtacaagggtt taccgggt $\frac{\text { Promotor AOX1 }}{2}>$

DraI
PmeI

aaactgacagt t taaacgctgtct tggaacctaatatgacaaaagcgtgatctcatccaagatgaactaagtt tggttcgttgaaatgctaacggccagt

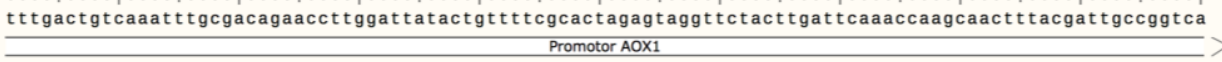

tggtcaaaaagaacttccaaaagtcggcataccgtt tgtcttgtt tggtat tgattgacgaatgctcaaaaataatctcat taatgcttagcgcagtct $\underset{\text { accagt tet tct tgaaggtt tcagccgtatggcaaacagaacaaccataactaactgct tacgagtt t tat tagagtaat tacgaatcgcgtcaga }}{\text { Promotor AOX1 }}$

ctctatcgcttctgaaccccggtgcacctgtgccgaaacgcaaatggggaacacccgctttt tggatgat tatgcattgtctccacat tgtatgct tcc gagatagcgaagact tggggccacgtggacacggct t tgcgtt taccctt tgtgggcgaaaacctactaatacgtaacagaggtgtaacatacgaagg Promotor AOX1

Bstx

aagat tctggtgggaatactgctgatagcctaacgt tcatgatcaaaat t taactgttctaaccctact tgacagcaatatataacagaaggaagctg ttctaagaccaccettatgacgactatcggat tgcaagtactagt tt taat tgacaagat tggggatgaactgtcgt tatatat tgtct tcct tcgac Promotor AOX1

\section{MfeI HindIII}

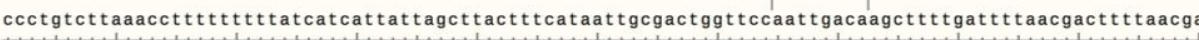
gggacagaatt tggaaaaaaaatagtagtaataatcgaatgaaagtat taacgctgaccaaggt taactgttcgaaactaaaat tgctgaaaat gct Promotor AOX1

BstBI

BstAPI

caact tgagaagatcaaaaacaactaat tat tcgaaacgatgagat t tccttcaat t t tact gctgtt t tat tcgcagcatcctccgcat tagctgct gttgaactcttctagtttettgttgat taataagctttgctactctaaggaagt taaaatgacgacaaaatagegtcgtaggaggcgtaatcgacga $\frac{{ }_{\text {Promotor AOX1 }}}{\underbrace{}_{\text {Fator-a }}}$ $\square$

ccagtcaacactacaacagaagatgaaacggcacaaat tccggctgaagctgtcatcggttactcagat t tagaagggatt tcgatgttgctgtt t tgc ggtcagttgtgatgttgtcttctactt gccgtgtttaaggccgacttcgacagtagccaatgagtctaaatcttccctaaagctacaacgacaaacg ggtcagt tgtgatgttgtct ctact t gccgtgtt aaggccgact tcgacagtagccaatgagtctaaatct tccctaaagctacaacgacaaacg

cat t t tccaacagcacaaataacgggt tat tgt t tataaatactactat tgccagcat tgctgctaaagaagaaggg tatctctcgagaaagagaggc gtaaaggttgtcgtgtt tattgcccaataacaatat t atgatgat aacggtcgtaacgacgatt tct tct tcccatagagagctctttetctcc

ECORI Nde

tgaagctgaat tcagccat catcatcatcatcacagcagcggcctggtgccgcgcggcagccatatgcagacaaggat tgcatgggccaggactgagct t act tcgact taagtcggtagtagtagtagtagtgtcgtcgccggaccacggcgegccgtcggtatacgtctgt tcctaacgtaccoggtcctgactcgaa Fator-a $\quad$ 6xHis-tag $\quad$ Trombina ctcaatgtctgcatgaacgccaagcaccacaaggaaaagccaggccccgaggacaagt tgcatgagcagtgtcgaccetggaggaagaatgcctgctgt gagttacagacgtact geggttcgtggtgttccttttcggtccgggetcctgttcaacgtactegtcacagctgggacctcettcttacggacgacaa FRo

ctaccaacaccagccaggaagcccataaggat $\mathrm{t} t \mathrm{t}$ tcctacctatatagat t caact ggaaccactgtggagagat ggcacctgcctgcaaacggcat $t$ gatggttgtggtcggtccttcgggtat tcctacaaagatggatatatctaagt tgaccttggtgacacctctctaccgtggacggacgtt tgccgtaaa FRo 


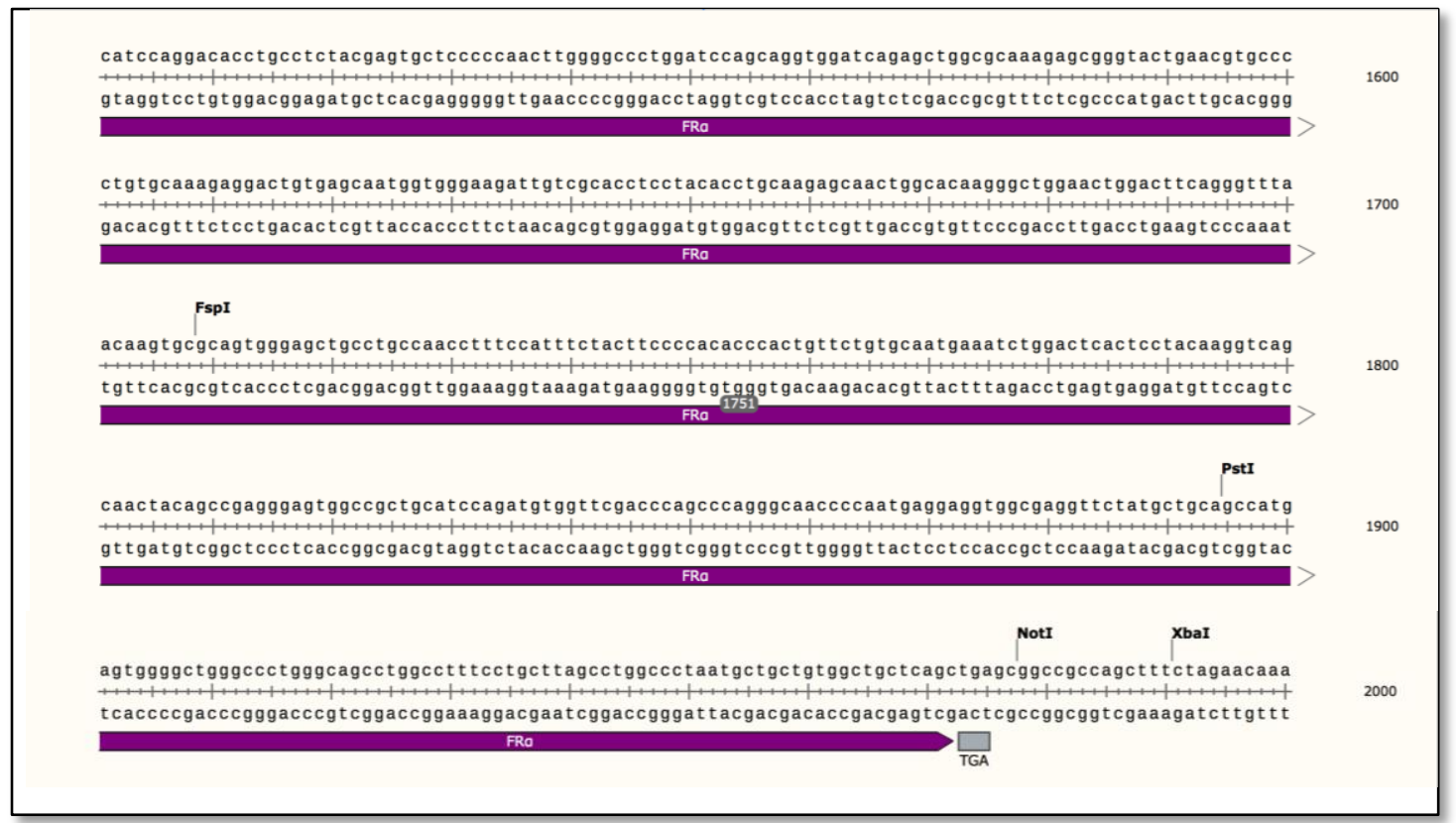

Fonte: Autoria própria com auxílio do software SnapGene.

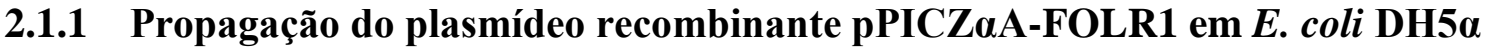

A propagação dos clones pPICZaA-FOLR1 foi promovida através da transformação de células E. coli DH5a selecionadas em meio sólido Low Salt LB contendo $25 \mu \mathrm{g} \mathrm{mL}^{-1}$ de Zeocina $^{\mathrm{TM}}$. Cabe salientar que a concentração de sal do meio deve ser inferior a $90 \mathrm{mmol} \mathrm{L}^{-1}$, pH 7,5, para que este antibiótico esteja ativo. (42)

\subsubsection{Linearização do plasmídeo recombinante pPICZaA-FOLR1}

A linearização de $10 \mu \mathrm{g}$ do vetor recombinante (pPICZ $\alpha$ A-FOLR1) foi promovida com a endonuclease SacI (Fermentas), para tornar possível a integração no genoma da célula hospedeira. Essa integração é feita de forma a regenerar o gene AOX1 interrompido da cepa de $P$. pastoris KM71H. (42) O DNA linearizado foi purificado por precipitação com clorofórmio, $3 \mathrm{~mol} \mathrm{~L}^{-1}$ de acetato de sódio e etanol, e utilizado para transformar a levedura $P$. pastoris cepa $\mathrm{KM} 71 \mathrm{H}$. 


\subsection{Preparação de $P$. pastoris KM71H eletrocompetente}

Para a transformação, a cepa KM71 foi tratada para que se tornasse eletrocompetente. Desta forma, uma única colônia foi cultivada em $5 \mathrm{~mL}$ de meio YPD (yeast extract peptone dextrose) a $30{ }^{\circ} \mathrm{C}, 250 \mathrm{rpm}$, por $12 \mathrm{~h}$, e, posteriormente inoculadas em $500 \mathrm{~mL}$ de YPD sob as mesmas condições. Após atingir a D.O.600 1,3 - 1,5, as células foram coletadas por centrifugação a $1500 \times \mathrm{g}, 4^{\circ} \mathrm{C}$, por $5 \mathrm{~min}$. Em seguida, foram lavadas com $200 \mathrm{~mL}$ e $120 \mathrm{~mL}$ de água destilada gelada estéril e coletadas após centrifugação a $1500 \times$ g, por 5 min, a $4{ }^{\circ} \mathrm{C}$. Após a lavagem, as células foram ressuspendidas em $20 \mathrm{~mL}$ de sorbitol $1 \mathrm{~mol} \mathrm{~L}^{-1}$ estéril gelado e novamente coletadas por centrifugação a $1500 \times \mathrm{g}$, por $5 \mathrm{~min}$, a $4{ }^{\circ} \mathrm{C}$. Por fim, as células foram concentradas em 1,0 mL de sorbitol $1 \mathrm{~mol} \mathrm{~L}^{-1}$ estéril gelado. (42)

\subsection{Transformação com plasmídeo recombinante pPICZaA-FOLR1}

A transformação foi realizada com $10 \mu \mathrm{L}$ de DNA linearizado (5-15 $\mu$ g de DNA) e 80 $\mu \mathrm{L}$ de células competentes em sorbitol $1 \mathrm{~mol} \mathrm{~L}^{-1}$, em cubeta de eletroporação de $0,2 \mathrm{~cm}$ gelada em eletroporador BioRad Genepulser, a 2500 V, $200 \Omega, 25 \mu \mathrm{F}$. Imediatamente após o choque, $1 \mathrm{~mL}$ de sorbitol $1 \mathrm{~mol} \mathrm{~L}^{-1}$ estéril gelado foi cuidadosamente adicionado na própria cubeta e, em seguida, todo volume foi transferido para tubos estéreis de $15 \mathrm{~mL}$, onde as células foram mantidas por $1 \mathrm{~h} 30$ min a $30{ }^{\circ} \mathrm{C}$ sem agitação. $\mathrm{O}$ conteúdo da transformação foi analisado em diferentes concentrações $(25,50,75$ e $100 \mu \mathrm{L})$, em meio sólido YPDS com 100 $\mu \mathrm{g} \mathrm{ml}^{-1}$ de Zeocina ${ }^{\mathrm{TM}}$ e mantidos por 2-3 dias, até o aparecimento de colônias. As colônias resistentes deste screening foram estriadas no mesmo meio sólido, desta vez contendo 1000 $\mu \mathrm{g} \mathrm{ml}^{-1}$ de Zeocina ${ }^{\mathrm{TM}}$, como forma de seleção de prováveis recombinantes contendo múltiplas cópias do DNA linearizado. (42) 


\subsection{Análise da presença da região codificadora do gene FOLR1 no genoma de $P$. pastoris}

\subsubsection{Isolamento do DNA genômico de $P$. pastoris}

Amostras das colônias transformantes foram ressuspendidas em $600 \mu \mathrm{L}$ de tampão de extração $\left(0,5 \mathrm{~mol} \mathrm{~L}^{-1}\right.$ de cloreto de sódio, 0,05 mol L ${ }^{-1}$ de EDTA, 0,1 mol L ${ }^{-1}$ Tris, pH 8,0 e $0,2 \% \mathrm{v} / \mathrm{v}$ de $\beta$-mercaptoetanol). Posteriormente, $50 \mu \mathrm{L}$ de SDS $20 \%(\mathrm{~m} / \mathrm{v})$ foram adicionados à suspensão, agitados por 1 min e mantidos a $60^{\circ} \mathrm{C}$ por $15 \mathrm{~min}$. Foram adicionados $300 \mu \mathrm{L}$ de acetato de potássio $5 \mathrm{~mol} \mathrm{~L}^{-1}$ e a mistura foi levemente agitada. O sobrenadante foi recuperado por centrifugação a $13000 \times \mathrm{g}$, por $10 \mathrm{~min}$, e transferido para um tubo limpo, ao qual foram adicionados $700 \mu \mathrm{L}$ de isopropanol sob agitação branda. O DNA foi coletado por centrifugação a $13000 \times$ g por $5 \mathrm{~min}$, seco em estufa a $37{ }^{\circ} \mathrm{C}$, e ressuspendido em $50 \mu \mathrm{L}$ de água autoclavada.

\subsubsection{Análise das colônias transformantes por PCR}

A análise das colônias transformantes por PCR, a partir do DNA genômico extraído, foi realizada com primers específicos, FOLR1F e FOLR1R, além dos oligonucleotídeos iniciadores do próprio vetor, AOX1 foward e reverse, Tabela 3.

Aproximadamente $1 \mu \mathrm{g}$ de DNA genômico de leveduras foi adicionado à reaçãopadrão em um volume total de $25 \mu \mathrm{L}$, usando $2 \mathrm{U}$ de Taq DNA polimerase (DNA Express) e seguindo o mesmo programa padronizado para a PCR de obtenção do gene FOLR1, como descrito no item 2.4.1.1 do Capítulo 2. Para a confirmação da amplificação do fragmento de interesse, todo o conteúdo das reações foi analisado por eletroforese em gel de agarose $1 \%$ TAE, contendo brometo de etídio, conforme já descrito Seção 1.3 do Capítulo 2. 
Tabela 3 - Primers utilizados para reações de PCR.

\begin{tabular}{clc}
\hline Primer & \multicolumn{1}{c}{ Sequência } & Sítio \\
\hline FOLR1F & 5'GCATATGCAGACAAGGATTGCATGGGCCAGGAC & NdeI \\
& TGAGC & \\
FOLR1R & 5'C $\underline{ }$ TAGGAGTTATCAGCTGAGCAGCCACAGCAGCAT & XhoI \\
& 5'GACTGGTTCCAATTGACAAGC & \\
AOX1F & 5'GCAAATGGCATTCTGACATCC & \\
AOX1R & & \\
\hline
\end{tabular}

\subsection{Expressão da proteína rFRa}

Colônias de leveduras transformantes positivas foram cultivadas a $30{ }^{\circ} \mathrm{C}$, individualmente, em 1 L do meio BMGY (Buffered Glycerol-complex Medium: 1\% (m/v) de extrato de levedura, $2 \%(\mathrm{~m} / \mathrm{v})$ de peptona, 1,34\% (m/v) de YNB (Yeast Nitrogen Base), 0,4 $\mu \mathrm{g} \mathrm{mL} \mathrm{mL}^{-1}$ de biotina, $1 \%$ (v/v) de glicerol e $100 \mathrm{mmol} \mathrm{L}^{-1}$ tampão fosfato de potássio, $\mathrm{pH}$ 6,0), sob agitação de $250 \mathrm{rpm}$, até atingir D.O.600 entre 6-8 ( 30 h). As células foram coletadas por centrifugação de $1500 \times \mathrm{g}$, por $5 \mathrm{~min}$, à $25^{\circ} \mathrm{C}$ e ressuspendidas em $400 \mathrm{~mL}$ do meio BMMY (Buffered Methanol-complex Medium: 1\% (m/v) de extrato de levedura, 2\% (m/v) peptona, $1,34 \%(\mathrm{~m} / \mathrm{v})$ de YNB, $0,4 \mu \mathrm{g} / \mathrm{mL}$ de biotina, $0,5 \%$ (v/v) de metanol e $100 \mathrm{mmol} \mathrm{L}{ }^{-1}$ tampão fosfato de potássio, pH 6,0) para iniciar a indução da expressão do gene heterólogo. A cada intervalo de $24 \mathrm{~h}$, a cultura foi suplementada com metanol absoluto (100\%) de forma a atingir uma concentração final de $0,7 \%$ (v/v). O conteúdo final (após $144 \mathrm{~h}$ de indução) foi submetido a centrifugação a $10000 \times$ g, por $10 \mathrm{~min}$, a $25^{\circ} \mathrm{C}$. (42)

Um volume de $1 \mathrm{~mL}$ da cultura cultivada por $24,48,72,96,120$ e $144 \mathrm{~h}$ foi separado por centrifugação a $16000 \times \mathrm{g}$, por $20 \mathrm{~min}$, a $25{ }^{\circ} \mathrm{C}$. Os sobrenadantes (contendo proteínas extracelulares) foram analisados por eletroforese em condições desnaturantes (SDS-PAGE) a fim de se confirmar e dosar a expressão da proteína FR $\alpha$ e determinar o período ideal de cultivo após a indução. 


\subsection{Ensaio de solubilidade da proteína recombinante}

A proteína recombinante foi expressa com um fator de secreção (fator $\alpha$, obtido através da clonagem no plasmídeo pPICZ $\alpha \mathrm{A}$ (Life Technologies), o que permite que a mesma seja secretada pelo organismo e encontrada na fração do sobrenadante. Uma vez que a $P$. pastoris secreta apenas pequenos níveis de proteínas endógenas, o direcionamento da proteína recombinante para o meio extracelular pode servir como uma etapa de purificação inicial. ${ }^{19}$ Desta forma, ao se analisar o perfil de expressão apresentado pela levedura a cada 24 h (até 144 h), objetivou-se a determinação do período ideal de cultivo após a indução. As amostras foram submetidas a análise em SDS-PAGE e a revelação foi feita inicialmente com Coomassie Blue, e em análises posteriores com nitrato de prata, conforme já descrito na Seção 1.11.1.

\subsection{Purificação da proteína recombinante}

A fração solúvel foi filtrada em filtro $(0,45 \mu \mathrm{m})$ e adicionada à coluna previamente equilibrada (de resina de níquel). Após a lavagem promoveu-se a eluição através de gradiente de imidazol $\left(10\right.$ - $\left.250 \mathrm{mmol} \mathrm{L}^{-1}\right)$. As frações eluídas foram analisadas em gel de poliacrilamida, conforme descrito na Seção 1.11.1.

\subsection{Westen Blot}

Após a separação da amostra por SDS-PAGE, o gel foi submetido à etapa de transferência das proteínas para uma membrana de nitrocelulose, conforme descrito na Seção 1.11.1. A presença da proteína em fusão com a $6 \times$ His-tag foi analisada utilizando-se $o$ anticorpo Ni-NTA AP conjugate (Qiagen) (diluído 1:10000 em PBS-T) e revelação com pastilha SigmaFAST ${ }^{\text {TM }}$ BCIP®/NBT B5655 (Sigma). 


\section{Resultados e Discussão}

A expressão da proteína recombinante no sistema de $P$. pastoris foi iniciada como uma alternativa aos ensaios de expressão em $E$. coli, nos quais foi observada a presença da rFR $\alpha$ na fração insolúvel do lisado celular. Ainda, a expressão heteróloga em eucariotos como a levedura $P$. pastoris, proporcionaria modificações pós-traducionais, como formação de pontes dissulfeto, adição de certos tipos de lipídeos e O- e N-glicosilações, que auxiliam no enovelamento correto da proteína recombinante.

\subsection{Linearização do plasmídeo pPICZaAFOLR1 e transformação da linhagem KM71H de $P$. pastoris}

No caso da linhagem de $P$. pastoris escolhida, KM71 (his4 arg4 aox1D::ARG4), derivada da linhagem GS115, o gene cromossomal AOX1 foi deletado e substituído pelo gene ARG4, originando o fenótipo Mut ${ }^{\mathrm{S}}$, de baixa utilização de metanol, resultado da dependência do gene $\mathrm{AOX} 2$, que é muito mais fraco. Outra vantagem deste sistema de expressão é que $P$. pastoris prefere a respiração à fermentação, não sendo produzidos grandes quantidades dos produtos de fermentação, etanol e ácido acético, que podem ser tóxicos às células. (42)

Após a linearização do plasmídeo clonado pPICZ $\alpha$ A-FOLR1 com a endonuclease de restrição $S a c \mathrm{I}$, foi promovida a transformação de $P$. pastoris eletrocompetentes, em que foram obtidas 8 colônias recombinantes. O DNA genômico destas colônias foi extraído e analisado por eletroforese em gel de agarose 1\% (m/v), conforme Figura 29.

Figura 27 - Eletroforese em gel de agarose. Confirmação da extração do DNA genômico. Canaletas: 1 - 8 . Amostras do DNA genômico extraído de oito colônias distintas.

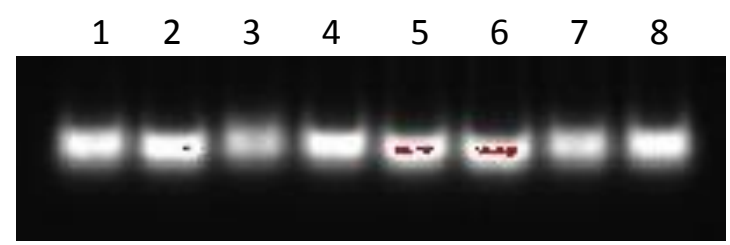

Fonte: Autoria própria 
Para confirmação da clonagem, foram promovidas PCRs em que os DNAs genômicos extraídos das colônias recombinantes serviram como DNA molde, e foram utilizados tanto os primers do vetor (AOX1, foward e reverse) como os próprios primers obtidos para amplificação do gene de interesse FOLR1 (FOLR1, foward e reverse), descritos na Tabela 3. Através da análise das Figuras 30 e 31, concluiu-se que todas as colônias obtidas se tratavam de transformantes positivos.

Figura 28 - Eletroforese em gel de agarose 1\%. Confirmação da clonagem do DNA genômico extraído através de PCR com primers 5'AOX1 e 3'AOX1. Canaletas: 1-8. Conteúdo da PCR das amostras do DNA genômico extraído das colônias 1-8, respectivamente. M: Padrão de 1 kb (Promega).

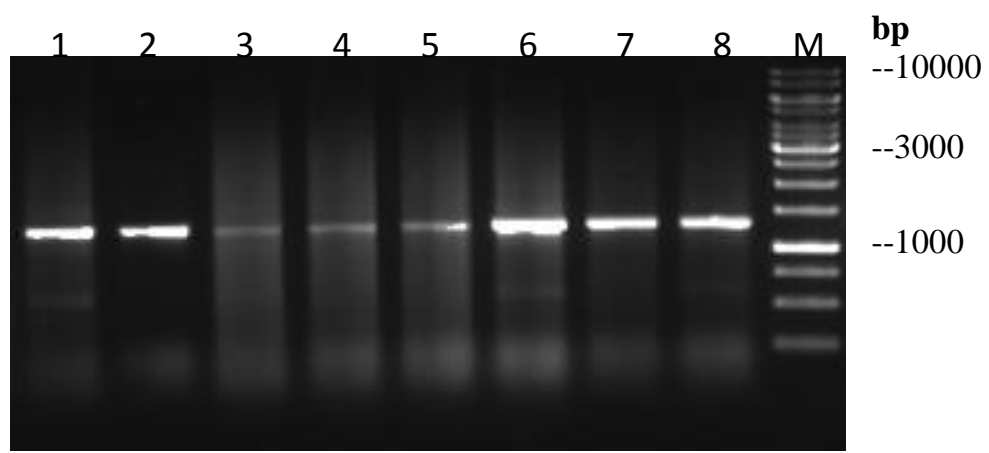

Fonte: Autoria própria

Figura 29 - Eletroforese em gel de agarose. Confirmação da clonagem do DNA genômico extraído através de PCR com primers FOLR1R e FOLR1F. Canaletas: 1. Padrão de $1 \mathrm{~kb}$ (Promega); 2. Controle negativo; 3-10. Conteúdo da PCR das amostras do DNA genômico extraído das colônias 1-8, respectivamente.

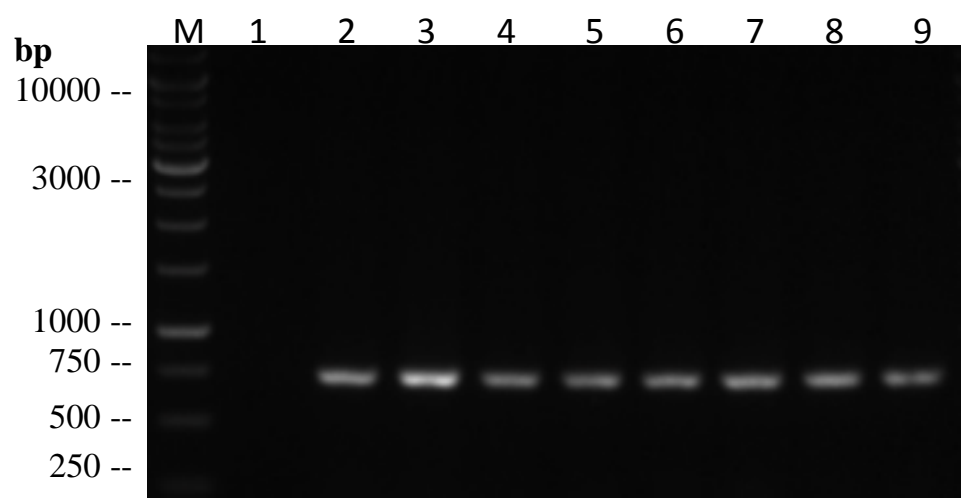

Fonte: Autoria própria 


\subsection{Expressão e ensaio de solubilidade da proteína recombinante $\mathrm{rFR} \alpha$ em $P$. pastoris}

A partir destes resultados, foram promovidos ensaios de expressão em pequena escala, com três diferentes colônias, escolhidas aleatoriamente. Em análises por SDS-PAGE corado com prata (Figura 32), não foram observadas bandas que poderiam evidenciar a expressão da proteína recombinante, ausência que foi confirmada pelas análises de Western Blot. Mesmo em experimentos em larga escala, o típico gel obtido foi semelhante ao da Figura 32. Há de se ressaltar que, por conta de reações como glicosilação, a massa molecular da proteína poderia ser maior que o esperado, $28,3 \mathrm{kDa}$.

A ausência da banda referente à proteína recombinante pode ser explicada pela não expressão ou pela possível ação de proteases, ou outros fatores externos que podem ter desestabilizado a estrutura da $\mathrm{rFR} \alpha$, promovendo a precipitação e/ou desnaturação da mesma.

Figura 30 - Perfil de eletroforese em gel de SDS-PAGE 15\% corado com prata. Expressão da $\mathrm{rFR} \alpha$ em $P$. pastoris a $30{ }^{\circ} \mathrm{C}$ em meio indutor BMMY, colônia 2. Canaletas: 1. Padrão de tamanho molecular (Fermentas); 2. Conteúdo proteico antes da indução $\left(\mathrm{t}_{\mathrm{o}}\right) ; 3$. Conteúdo proteico antes da indução $\left(\mathrm{t}_{\mathrm{o}}\right)$; 4-9. Conteúdo proteico depois de 24, 48, 72, 96, 120 e 144 h de indução, respectivamente.

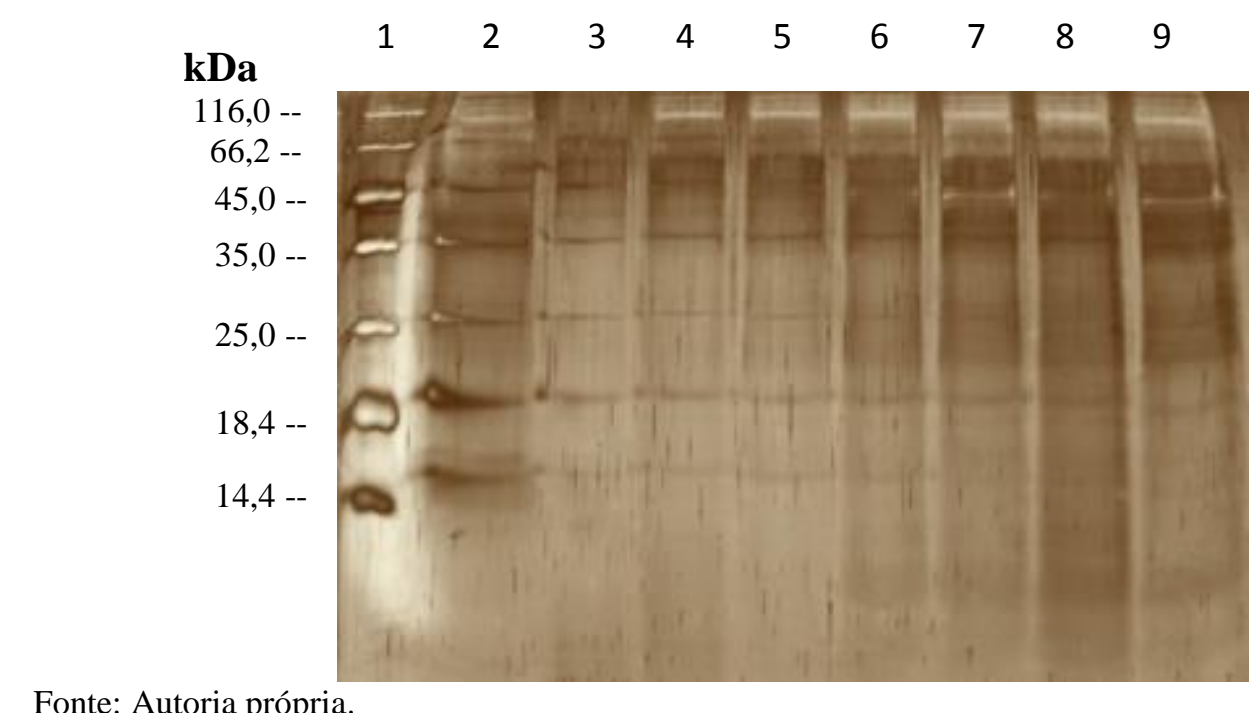

Fonte: Autoria própria.

Para comprovar a ausência da proteína recombinante em fusão com $6 \times$ His-tag foi promovido DotBlot com anticorpo anti-His, com as amostras concentradas $10 \times\left(\mathrm{t}_{\mathrm{o}}, \mathrm{t}_{24} \mathrm{~h}, \mathrm{t}_{48} \mathrm{~h}\right.$, 
$\mathrm{t}_{72 \mathrm{~h}}, \mathrm{t}_{96 \mathrm{~h}}, \mathrm{t}_{120 \mathrm{~h}}, \mathrm{t}_{144 \mathrm{~h}}$ ) das expressões e, mesmo nos experimentos de maior escala, a presença da proteína recombinante não foi comprovada.

Uma vez que foi comprovado o sucesso na etapa de clonagem, acredita-se que tenha ocorrido algum problema na etapa de expressão da proteína. Por se tratar de uma proteína com muitas pontes dissulfeto, talvez este não seja o sistema adequado para expressão, impossibilitando o enovelamento correto da proteína. Visto que as frações analisadas pertencem ao conteúdo extracelular, poucas informações foram obtidas do conteúdo intracelular, local em que a proteína pode estar situada em forma de corpos de inclusão. Entretanto, por se tratar de um sistema de expressão demorado e muito trabalhoso, optou-se por interromper os experimentos neste sistema. Deve-se destacar que, para a expressão de determinadas proteínas descritas na literatura, esse sistema se mostrou bastante eficaz, revelando sua importância. 


\section{Conclusões}

O trabalho desenvolvido nesse capítulo não pode ser concluído conforme o esperado uma vez que não foi comprovada a expressão da proteína recombinante. Este sistema foi escolhido como alternativa ao sistema de expressão inicialmente testado, E. coli. Contudo, por mais que este sistema de expressão permita o processamento pós-traducional, não foi possível a confirmação da expressão da proteína $\mathrm{rFR} \alpha$, nem em expressões em grande escala. Se produzida, os níveis eram muito baixos para ser detectado, ou estava presente na forma de corpos de inclusão. A manutenção de células de levedura se mostrou muito demorada e trabalhosa, além de apresentar custos elevados, o que motivou o fim dos experimentos neste sistema de expressão. Portanto, conclui-se que o sistema de expressão utilizado não se mostrou eficiente para esta aplicação. 
Capítulo 4

Conclusões Gerais e

Perspectivas Futuras 
Este trabalho compreendeu um estudo da expressão do alfa receptor de folato através de técnicas de engenharia genética e biologia molecular disponíveis. Foram testados dois sistemas de expressão, sendo um procarioto e outro eucarioto. Contudo, diferentemente do que se esperava, a expressão da proteína recombinante na forma solúvel só foi confirmada em E. coli, em fusão com uma proteína de alta solubilidade que atua também como chaperona molecular. A construção com a proteína Trigger factor possibilitou que análises posteriores fossem promovidas, como a imobilização em partícula lipossômica. Deve-se ressaltar ainda o êxito na utilização deste sistema de expressão procarioto para a expressão do receptor de Homo sapiens, uma vez que não foi relatada anteriormente na literatura. Ainda, os resultados obtidos nos experimentos com microbalança de cristal de quartzo comprovam a afinidade do FR $\alpha$ recombinante ao ligante testado, o que viabiliza a utilização deste receptor em testes futuros.

As técnicas analíticas utilizadas para detecção da proteína recombinante, em especial LC-MS e Western Blot, mostraram-se adequadas e eficientes para a proposta apresentada, podendo ser consideradas complementares. Deve ser destacado que, através na análise convencional dos resultados processados pelo software SEQUEST, não foi comprovada a presença do receptor recombinante. Para circunvir este problema, foram promovidas digestões virtuais e, os peptídeos esperados foram comparados com aqueles detectados pela análise real, o que originou resultados interessantes e que comprovaram a presença da proteína recombinante TF-FR $\alpha$. Este resultado mostra a importância da análise minuciosa dos dados gerados pelo software, uma vez que ainda não existem parâmetros muito bem estabelecidos, podendo levar a erros.

Conclui-se que houve sucesso na produção do receptor recombinante e sua imobilização em microssistema lipídico, o que deu início aos estudos para a produção de uma CTC-mimética. A utilização de lipídios niquelados possibilitou a imobilização do receptor através da cauda de histidina presente na porção N-terminal, ou seja, antes da TF. Imobilizações como esta já foram descritas na literatura, porém podemos considerar que esta pesquisa foi pioneira na tentativa de mimetizar uma célula tumoral através da utilização do biomarcador FR $\alpha$. 
Um ponto relevante a considerar é a importância da colaboração no âmbito de pesquisa, uma vez que para o desenvolvimento do trabalho, diferentes opiniões e colaborações foram relevantes para a obtenção dos resultados obtidos.

Uma possibilidade de continuação da pesquisa é o estudo da cinética da reação do receptor recombinante com o biosensor desenvolvido por Lima et. al. (2010). Existem, ainda, perspectivas de trabalhos futuros para o desenvolvimento de biossensores baseados na detecção deste receptor, principalmente os de baixo custo, área na qual o grupo BioMicS possui grande interesse. 


\section{REFERÊNCIAS BIBLIOGRÁFICAS}

\section{INSTITUTO NATCIONAL DE CÂNCER JOSÉ ALENCAR GOMES DA SILVA.}

Câncer: o que é. Disponível em: 〈http://www1.inca.gov.br/conteudo_view.asp?id=322>. Acesso em: 14 maio 2014.

2. LIMA, R.S. Biossensor condutométrico sem contato em microchip contendo ácido fólico como biorreceptor. 2010. 138f. Dissertação (Mestrado em Química Analítica e Inorgânica) - Instituto de Química de São Carlos, Universidade de São Paulo, São Carlos, 2010 .

3. KELEMEN, L.E. The role of folate receptor alpha in cancer development, progression and treatment: cause, consequence or innocent bystander? International Journal of Cancer. v. 119, n. 2, p. 243-50, 2006.

4. BRAY, F.; JEMAL, A.; GREY, N.; FERLAY, J.; FORMAN, D. Global cancer transitions according to the Human Development Index (2008-2030): a population-based study. The Lancet Oncology, v. 13, n. 8, p. 790-801, 2012.

5. VAITILINGAM, B.; CHELVAM, V.; KULARATNE, S. A.; POH, S.; AYALA-LOPEZ, W.; LOW, P. S. A folate receptor- $\alpha$-specific ligand that targets cancer tissue and not sites of inflammation. Journal of Nuclear Medicine : official publication, Society of Nuclear Medicine, v. 53, n. 7, p. 1127-34, 2012.

6. U.S. FOOD AND DRUG ADMINISTRATION. Drugs: biomarker qualification. Silver Spring, 2014. Disponível em:

<http://www.fda.gov/Drugs/DevelopmentApprovalProcess/DrugDevelopmentToolsQualificat ionProgram/ucm284076.htm> Acesso em: 15 maio 2014.

7. GOODSAID, F.; PAPALUCA, M. Evolution of biomarker qualification at the health authorities. Nature Biotechnology, v. 28, n. 5, p. 441-3, 2010.

8. BREAST CANCER ORG. Blood Marker Tests. Ardmore, PA, 2013. Disponível em: <http://www.breastcancer.org/symptoms/testing/types/blood_marker>. Acesso em: 15 maio 2014.

9. ELNAKAT, H.; RATNAM, M. Distribution, functionality and gene regulation of folate receptor isoforms: implications in targeted therapy. Advanced Drug Delivery Reviews, v. 56, n. 8, p. $1067-84,2004$.

10. ANTONY, A. C. The Biological Chemistry of Folate Receptors. BLOOD The Journal of The American Society of Hematology, v. 79, n. 11, p. 2807-2820, 1992. 
11. SIU, M.K.Y.; KONG, D.S.H.; CHAN, H. Y.; WONG, E S. Y.; IP, P. P. C.; JIANG, L.; NGAN, H. Y. S.; LE, X.-F.; CHEUNG, A. N. Y. Paradoxical impact of two folate receptors, FR $\alpha$ and RFC, in ovarian cancer: effect on cell proliferation, invasion and clinical outcome.

PloS one, v. 7, n. 11, p. e47201, 2012.

12. SALAZAR, M. D.; RATNAM, M. The folate receptor: what does it promise in tissuetargeted therapeutics? Cancer and Metastasis Reviews, v. 26, p. 141-152, 2007.

13. NATIONAL CENTER FOR BIOTECHNOLOGY. FOLR1 folate receptor 1 (adult) [ Homo sapiens ( human ) ]. 2014. Disponível em: <http://www.ncbi.nlm.nih.gov/gene/2348>. Acesso em: 14 maio 2014.

14. O'SHANNESSY, D.J.; SOMERS, E.B.; SMALE, R.; FU, Y.-S. Expression of folate receptor- $\alpha$ (FRA) in gynecologic malignancies and its relationship to the tumor type. International journal of gynecological pathology: official journal of the International Society of Gynecological Pathologists, v. 32, n. 3, p. 258-68, 2013.

15. HENDERSON, G.B. Folate-binding proteins. Annual Review of Nutrition, v. 10, p. 319-35, 1990.

16. SHEN, F.; WANG, H.; ZHENG, X.; RATNAM, M. Expression levels of functional folate receptors $\alpha$ and $\beta$ are related to the number of $\mathrm{N}$-glycosylated sites. Biochemical Journal, $\mathrm{v}$. 764, p. 759-764, 1997.

17. CHEN, C.; KE, J.; ZHOU, X. E.; YI, W.; BRUNZELLE, J. S.; LI, J.; YOUNG, E.-L.; $\mathrm{XU}, \mathrm{H}$. E. Structural basis for molecular recognition of folic acid by folate receptors. Nature, v. 500, n. 7463, p. 486-9, 2013.

18. BUENO, R.; APPASANI, K.; MERCER, H.; LESTER, S.; SUGARBAKER, D. The alpha folate receptor is highly activated in malignant pleural mesothelioma. The Journal of Thoracic and Cardiovascular Surgery, v. 121, n. 2, p. 225-33, 2001.

19. WU, M.; GUNNING, W.; RATNAM, M. Expression of Folate Receptor Type $\alpha$ in Relation to Cell Type, Malignancy, and Differentiation in Ovary, Uterus, and Cervix Expression of Folate Receptor Type $\alpha$ in Relation to Cell Type, Malignancy, and Differentiation in Ovary, Uterus, and Cervix. American Association for Cancer Research, v. 8, p. 775-782, 1999.

20. PARKER, N.; TURK, M. J.; WESTRICK, E.; LEWIS, J. D.; LOW, P. S.; LEAMON, C. P. Folate receptor expression in carcinomas and normal tissues determined by a quantitative radioligand binding assay. Analytical Biochemistry, v. 338, n. 2, p. 284-93, 2005.

21. LEUNG, F; DIMITROMANOLAKIS, A; KOBAYASHI, H; DIAMANDIS, E P; KULASINGAM, V. Folate-receptor 1 (FOLR1) protein is elevated in the serum of ovarian cancer patients. Clinical Biochemistry, v. 46, n. 15, p. 1462-8, 2013. 
22. SHIA, J.; KLIMSTRA, D. S.; NITZKORSKI, J. R.; LOW, PHILIP, S.; GONEN, M.; LANDMANN, R.; WEISER, M. R.; FRANKLIN, W. A.; PRENDERGAST, F. G.; MURPHY, L.; TANG, L. H.; TEMPLE, L.; GUILLEM, J. G.; WONG, W. D.; PATY, P. B. Immunohistochemical expression of folate receptor alpha in colorectal carcinoma: patterns and biological significance. Human Pathology, v. 39, n. 4, p. 498-505, 2008.

23. WEBER, C. J.; MÜLLER, S.; SAFLEY, S. A.; GORDON, K. B.; AMANCHA, P.; VILLINGER, F.; CAMP, V. M.; LIPOWSKA, M.; SHARMA, J.; MÜLLER, C.; SCHIBLI, R.; LOW, P. S.; LEAMON, C. P.; HALKAR, R. K. Expression of functional folate receptors by human parathyroid cells. Surgery, v. 154, n. 6, p. 1385-93; discussion 1393, 2013.

24. CAGLE, P.T.; ZHAI, Q.J.; QIHUI, J.; MURPHY, L.; LOW, P. S. Folate receptor in adenocarcinoma and squamous cell carcinoma of the lung: potential target for folate-linked therapeutic agents. Archives of Pathology \& Laboratory Medicine, v. 137, n. 2, p. 241-4, 2013.

25. HASSAN, A.; THOMAS, J.; MALTZMAN, R. Farletuzumab in Lung Cancer. Lung Cancer, v. 80, n. 1, p. 15-18, 2013.

26. WIBOWO, A. S.; SINGH, M.; REEDER, K. M.; CARTER, J. J.; KOVACH, A. R.; MENG, W.; RATNAM, M.; ZHANG, F.; DANN, C. E. Structures of human folate receptors reveal biological trafficking states and diversity in folate and antifolate recognition.

Proceedings of the National Academy of Sciences of the United States of America, v. 110, n. 38, p. 15180-15188, 2013.

27. HOLTZHAUER, M. Basic methods for the biochemical lab. Berlin: Springer, p. 31-75, 2006.

28. PRECKEL, T. Novel prefractionation technology enables more protein identifications. Agilent Technologies, (18), 1-2, 2007. Disponível em: <http://www.chem.agilent.com/cag/Pharmanews/Pharma18/newsletter.asp?page=PN_18_F4_ OFFGEL.html>. Acesso em: 12 maio 2014.

29. INFICON. Operation and service manual: research quartz crystal microbalance. Syracuse, 2007. Disponível em: <http://products.inficon.com/GetAttachment.axd?attaName=6538a92e-efcf-4dc2-ba00$1297 \mathrm{c} 15 \mathrm{~b} 938 \mathrm{e}>$. Acesso em: 31 maio 2014.

30. COLHONE, M.C.; NOBRE, T.M.; THATYANE, M.; ZANIQUELLI, M. E. D.; STABELI, R. G.; CIANCAGLINI, P. Incorporation of antigenic GPI-proteins from Leishmania amazonensis to membrane mimetic systems: influence of DPPC/cholesterol ratio. Journal of Colloid and Interface Science, v. 333, n. 1, p. 373-9, 2009.

31. SANTOS, H. L.; LOPES, M. L.; MAGGIO, B.; CIANCAGLINI, P. Na,K-ATPase reconstituted in liposomes: effects of lipid composition on hydrolytic activity and enzyme orientation. Colloids and Surfaces. Biointerfaces, v. 41, n. 4, p. 239-48, 2005. 
32. ARRIAGA, L.R.; DATTA, S.S.; KIM, S.-H.; AMSTAD, E.; KODGER, T. E.; MONROY, F.; WEITZ, D. A. Ultrathin Shell Double Emulsion Templated Giant Unilamellar Lipid Vesicles with Controlled Microdomain Formation. Small (Weinheim an der Bergstrasse, Germany), p. 1-7, 2013.

33. PNANOSCIENCE INSTRUMENTS Inc. Technology overview: scanning electron microscopy, atomic force microscopy. [201-]. Disponível em:

<http://www.nanoscience.com/products/sem/technology-overview/>. Acesso em: 20 maio 2014.

34. MICHAUX, C.; POUYEZ, J.; WOUTERS, J.; PRIVÉ, G. G. Protecting role of cosolvents in protein denaturation by SDS: a structural study. BMC Structural Biology, v. 8, p. 29, 2008.

35. SHEVCHENKO, A.; TOMAS, H.; HAVLIS, J.; OLSEN, J. V.; MANN, M. In-gel digestion for mass spectrometric characterization of proteins and proteomes. Nature Protocols, v. 1, n. 6, p. 2856-60, 2006.

36. THERMOFISHER SCIENTIFIC. Proteome Discoverer User Guide 1.2.0. [201-]. Disponível em:

$<$ http://sjsupport.thermofinnigan.com/public/docs/detail_doc.asp?offset=180\&manualID=149 9>. Acesso em: 10 maio 2014.

37. AVANTI POLAR LIPIDS. Lipids and preparation of liposomes. [201-]. Disponível em: < http://avantilipids.com>. Acesso em: 20 maio 2014.

38. FAN, D.-J.; DING, Y.-W.; ZHOU, J.-M. Structural rearrangements and the unfolding mechanism of a Trigger Factor mutant studied by multiple structural probes. Biochimica et Biophysica Acta, v. 1794, n. 6, p. 944-52, 2009.

39. HOFFMANN, E. D.; STROOBANT, V. Mass spectrometry. Chichester: JohnWiley, 2007. 489p.

40. NOVATIA. What Constitutes a Good " Hit" from a SEQUEST Search. [201-]. Disponível em: < http://www.enovatia.com/services/ms/ms-resources/sequest-tips/what-is-agood-sequest-hit/>. Acesso em: 31 maio 2014.

41. DELMAR, M.; CARRILHO, E.; WULFF, N. A.; PALMA, M. S. Seqüenciamento de peptídeos usando espectrometria de massas: um guia prático. Química Nova, v. 31, n. 3, p. 669-675, 2008.

42. LIFE TECHNOLOGIES. User manual: EasySelectTM Pichia Expression Kit For Expression of Recombinant Proteins Using pPICZ and pPICZ $\alpha$ in Pichia pastoris Cat. no. K1740-01. Carlsbad, CA 2010. 87 p. 